\title{
Durability Testing of Heavy-Ion Irradiated Crystalline Ceramics
}

by

C. Crawford

Westinghouse Savannah River Company

Savannah River Site

Aiken, South Carolina 29808

c. Biddle

N. Bibler

DOE Contract No. DE-AC09-96SR18500

This paper was prepared in connection with work done under the above contract number with the U.S.

Department of Energy. By acceptance of this paper, the publisher and/or recipient acknowledges the U. S.

Government's right to retain a nonexclusive, royalty-free license in and to any copyright covering this paper, along with the right to reproduce and to authorize others to reproduce all or part of the copyrighted paper. 


\title{
Durability Testing of Heavy-Ion-Irradiated Crystalline Ceramics (U)
}

\section{Authors:}

\section{Charles L. Crawford \\ Crystal R. Biddle \\ Ned E. Bibler}

\author{
Distribution: \\ SRTC \\ L. M. Papouchado, 773-A \\ E. W. Holtzscheiter, 773-A \\ D. T. Rankin, 773-A \\ C. R. Goetzman, 773-A \\ J. R. Harbour, 773-43A \\ D. A. Crowley, 773-43A \\ T. K. Snyder, 704-1T \\ K. E. Mottel, 773-43A \\ J. W. Congdon, 773-A \\ J. M. Pareizs, 773-A \\ A. D. Cozzi, 773-43A \\ J. C. Marra, 773-43A \\ S. L. Marra, 704-T \\ K. M. Marshall, 773-A \\ K. G. Brown, 704-1T \\ M. E. Smith, 773-43A \\ R. F. Schumacher, 773-43A \\ N. E. Bibler, 773-A \\ C. L. Crawford, 773-41A \\ J. M. Mckibben, 773-41A \\ I. K. Sullivan, 773-41A \\ C. M. Jantzen, 773-A \\ G. G. Wicks, 773-A
}
SRTC, Continued
D. K. Peeler, 773-43A
R. L. Schulz, 773-A
T. L. Fellinger, 773-A
W. F. Ayres, 773-41A
J. C. Dozier (Records Mgt.), 773-52A
LLNL:
H. F. Shaw
B. B. Ebbinghaus
T. H. Gould
T. Kan
W. L. Bourcier
R. A. Van konynenburg
PNNL:
D. M. Strachan
J. D. Vienna
B. P. McGrail
W. J. Weber
ANL:
D. B. Chamberlain
A. J. Bakel

Publication Date: August 9, 1999

Westinghouse

Savannah River Company

Aiken, SC 29808 
DISCLAIMER

\section{DISCLAIMER}

This report was prepared as an account of work sponsored by an agency of the United States Government. Neither the United. States Government nor any agency thereof, nor any of their employees, makes any warranty, express or implied, or assumes any legal liability or responsibility for the accuracy, completeness, or usefulness of any information, apparatus, product, or process disclosed, or represents that its use would not infringe privately owned rights. Reference herein to any specific commercial product, process, or service by trade name, trademark, manufacturer, or otherwise does not necessarily constitute or imply its endorsement, recommendation, or favoring by the United States Government or any agency thereof. The views and opinions of authors expressed herein do not necessarily state or reflect those of the United States Government or any agency thereof.

This report has been reproduced directly from the best available copy.

Available to DOE and DOE contractors from the Office of Scientific and Technical Information, P.O. Box 62, Oak Ridge, TN 37831; prices available from (615) 576-8401.

Available to the public from the National Technical Information Service, U.S. Department of Commerce, 5285 Port Royal Road, Springfield, VA 22161. 


\section{DISCLAIMER}

Portions of this document may be illegible in electronic image products. Images are produced from the best available original document. 
TABLE OF CONTENTS

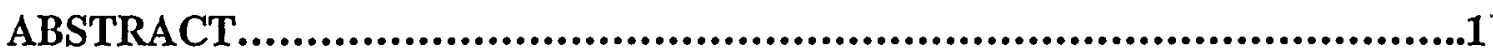

I. INTRODUCTION...........................................................2

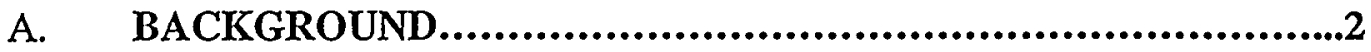

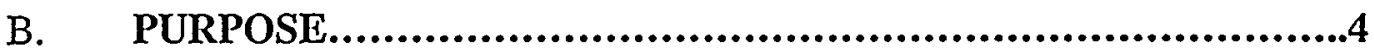

II. EXPERIMENTAL ...........................................................5

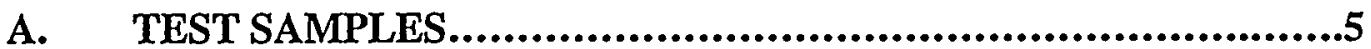

B. MCC-1 LEACH TESTS................................................6

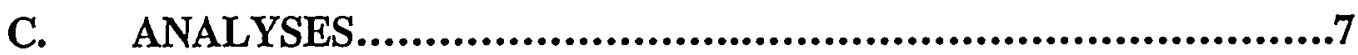

III. RESULTS AND DISCUSSION.............................................8

A. CALCIUM ANALYSIS AND pH TESTING OF CLEANED VESSELS ..........................................................8 8

B. LEACH TESTS WITH SRTC-FABRICATED BASELINE CERAMTCS.......................................................... 11

C. LEACH TESTS WITH IRRADIATED AND UNIRRADIATED PNNL-FABRICATED SINGLE-PHASE PYROCHLORE CERAMICS.

D. LEACH TESTS WITH IRRADIATED AND UNIRRADIATED PNNL-FABRICATED SINGLE-PHASE ZIRCONOLITE CERAMICS. 22

E. COMPARISON OF SRTC DATA TO LEACH TESTS CONDUCTED AT ARGONNE NATIONAL LABORATORY

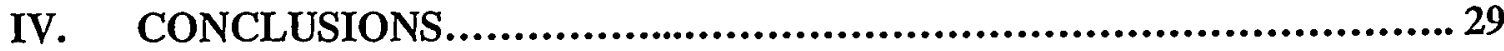

V. ACKNOWLEDGEMENTS.............................................. 30 
REFERENCES. 31

APPENDIX A: PACIFIC NORTHWEST NATIONAL LABORATORY REPORT ON ION IRRADIATION OF CERAMIC SAMPLES... 34

APPENDIX B: SAVANNAH RIVER TECHNOLOGY CENTER BASELINE CERAMIC FORMULATION....................................... 45

APPENDIX C: ANALYTICAL DATA FOR CALCIUM ANALYSES FROM SRTC A0 BASELINE CERAMIC LEACH TESTS................. 48

APPENDIX D: ANALYTICAL DATA FOR CALCIUM ANALYSES FROM IRRADIATED AND UNIRRADIATED PNNLFABRICATED SINGLE-PHASE PYROCHLORE CERAMIC LEACH TESTS.

APPENDIX E: ANALYTICAL DATA FOR CALCIUM ANALYSES FROM IRRADIATED AND UNIRRADIATED PNNLFABRICATED SINGLE-PHASE ZIRCONOLITE CERAMIC LEACH TESTS. 


\title{
DURABILITY TESTING OF HEAVY-ION-IRRADIATED CRYSTALLINE CERAMICS
}

\author{
by

\section{Charles L. Crawford, Crystal R. Biddle and Ned E. Bibler}

\begin{abstract}
Development of a titanate-based crystalline ceramic form to immobilize surplus weapons-useable plutonium for disposition is the mission of the Plutonium Immobilization Project (PIP). A major development and testing activity for this program is performance testing and qualification of the wasteform for a repository. As part of the performance testing, the leaching behavior of the ceramic form must be evaluated to determine the anticipated repository behavior. To study the impact of radiation damage on the performance of the ceramic, the damage must be accelerated using techniques such as ${ }^{238} \mathrm{Pu}$ doping and ion irradiation.
\end{abstract}

The purpose of this report is to assess the effects of heavy-ion irradiation on the durability of pyrochlorerich baseline ceramics and single-phase pyrochlore, zirconolite and brannerite ceramics. Ion irradiation of ceramic pellet surfaces will transform the outermost several tenths of microns of the surface into a metamict (i.e., noncrystalline) state. Short-term monolithic leach tests on unirradiated and irradiated samples should elucidate any significant differences in the durability of the undamaged crystalline surface versus the damaged metamict surface. Data developed under this task will support a preliminary integrated data report to be supplied to the Office of Civilian Radioactive Waste Management (RW) for use in the license application for the candidate Yucca Mountain repository.

Irradiation of the ceramic pellets used in this study was carried out at the Environmental Molecular Sciences Laboratory at the Pacific Northwest National Laboratory. Both sides of each ceramic pellet were irradiated with $2 \mathrm{MeV} \mathrm{Au}{ }^{2+}$ ions to doses of $5.5 \times 10^{14}$ ions $/ \mathrm{cm}^{2}$. These irradiations are estimated to have produced amorphous surface layers of $\sim 0.3$ microns in the crystalline ceramics. The individual leach tests were limited to 1,3 , and 7 days so that only the amorphous layer was leached.

Results based on Ca of monolith leach tests on unirradiated pyrochlore-rich ceramic samples fabricated at SRTC indicate, as expected, that more $\mathrm{Ca}$ is leached in the longer tests. Normalized mass losses based on $\mathrm{Ca}$ in these tests were lower than results of similar tests at ANL. Normalized mass losses based on $\mathrm{Ti}, \mathrm{Ce}$, $\mathrm{Gd}$, and $\mathrm{Hf}$ were much lower than those based on $\mathrm{Ca}$.

Interpretation of the results from the irradiated and unirradiated single-phase pyrochlore samples was complicated by the fact that concentrations of the leached elements were often similar to or less than 
concentrations obtained in blank tests. Even so, the results of these tests indicate that the ceramic has very low normalized mass losses. This is true for both the irradiated and unirradiated samples. In those tests for which the blank concentrations were lower than the concentrations when the pellets were present, we cannot determine if there was a difference in leaching behavior between the irradiated and unirradiated samples. For the zirconolite sample, the amount of $\mathrm{Ca}$ in all the leach tests was higher than the blanks. These results indicate that irradiated samples leached similarly to the unirradiated samples.

Suggestions for further leach tests on untested pyrochlore-rich baseline and single-phase brannerite materials (and remaining unleached pure pyrochlore and zirconolite pellets) that were ion irradiated for this study include: 1) continuation of similar MCC-1 testing as was performed on the pyrochlore and zirconolite materials, at either Savannah River Technology Center or Argonne National Laboratory; and 2) leach testing of these materials using a single pass flow through design in order to possibly attain lower blanks, and hence greater sensitivity to differences in behavior between the irradiated and unirradiated samples.

\section{INTRODUCTION}

\section{A. Background}

The Plutonium Immobilization Project of the DOE's Office of Fissile Materials Disposition is developing a titanate-based ceramic form to immobilize surplus weapons-useable plutonium for disposition via the canin-canister technology [1-5]. A comprehensive report describing baseline ceramic formulation strategies, test plans and form specifications has also been issued [6].

The leaching behavior of the ceramic form must be evaluated to determine its behavior under repository conditions. It is expected that the alpha decay of $\mathrm{Pu}$ (and other elements) will cause the ceramic to become metamict (i.e., amorphous) after approximately 1000 years of decay, given the anticipated concentrations of radionuclides in the ceramic. To study the impact of radiation damage on the performance of the ceramic on laboratory timescales, the damage must be accelerated using techniques such as ${ }^{238} \mathrm{Pu}$ doping and ion irradiation. Considering plutonium immobilization in crystalline ceramics, the main radiation damage results from self-radiation damage associated with the alpha decay of incorporated ${ }^{239} \mathrm{Pu}$ (half-life $=24,360$ years). Accelerated damage to host ceramics can be achieved by doping ${ }^{238} \mathrm{Pu}$ into the bulk ceramic matrix. Plutonium-238 has a much shorter half-life of 86.4 years relative to ${ }^{239} \mathrm{Pu}$. Accelerated damage can also be achieved by irradiating the ceramic with a beam of heavy ions such as $\mathrm{Au}^{2+}$. Several leaching studies involving radiation-damaged ceramics have been previously reported [7-11], and suggest that radiation damage will decrease the durability of crystalline wasteforms. 
In the present Research, Development and Testing (RD\&T) program for the PIP, ${ }^{238} \mathrm{Pu}$ doping studies are being performed by Pacific Northwest National Laboratory (PNNL). Ion-irradiation studies are being performed by Savannah River Technology Center (SRTC) and PNNL. Pure (or nearly pure) pyrochlore, zirconolite, and brannerite ceramics, as well as the baseline pyrochlore-rich ceramic, all containing cerium as surrogate for plutonium and uranium, were fabricated, polished and irradiated with high-energy, heavy ions by PNNL personnel. These irradiations were performed at the Environmental Molecular Sciences Laboratory (EMSL). The fabrication and irradiation procedures are documented in Appendix $A$ of this report. All samples were delivered to SRTC after ion irradiation for subsequent leach testing using a monolith leach test in deionized water at $90^{\circ} \mathrm{C}$.

Ion irradiation has the advantage that very high doses can be implanted in the outermost ceramic sample surfaces in very short times. Heavy-ion bombardment primarily simulates alpha-recoil radiation damage from alpha-emitting radionuclides. Table 1 gives details for ${ }^{239} \mathrm{Pu}$ decay in zircon $\left(\mathrm{ZrSiO}_{4}\right)$ [7]. Data in Table 1 indicates that about five times more atomic displacements result from the recoil of the daughter ${ }^{235} \mathrm{U}$ nucleus than result from the higher energy alpha particle itself. For the purposes of studying radiation damage in crystalline ceramics, heavy ion radiation is the worst case test of alpha recoil damage due to the very high dose rates used. However, because ion irradiation damages only the surface of material, corrosion testing of irradiated material is limited to monolithic leach tests.

Table 1. Plutonium Alpha Decay in Zircon

\begin{tabular}{|l|l|l|l|l|l|}
\hline${ }^{239}$ Pu Decay & Particle & Energy & Range & $\begin{array}{l}\text { Average } \\
\text { Number of } \\
\text { Displacements }\end{array}$ & $\begin{array}{l}\text { Damage } \\
\text { Mechanisms }\end{array}$ \\
\hline & Alpha-particle & $5.16 \mathrm{MeV}$ & $16-22$ micrometers & 220 & $\begin{array}{l}\text { Major: ionization } \\
\text { Minor: elastic } \\
\text { scattering } \\
\text { collisions }\end{array}$ \\
\hline & $\begin{array}{c}{ }^{235} \mathrm{U} \text { recoil } \\
\text { nucleus }\end{array}$ & $0.086 \mathrm{MeV}$ & $30-40$ nanometers & 1180 & $\begin{array}{l}\text { Major: elastic } \\
\text { scattering } \\
\text { collisions }\end{array}$ \\
\hline
\end{tabular}

Recent comprehensive reviews have documented numerous radiation damage studies involving both glass and crystalline ceramics $[7,8]$. Corrosion festing of radiation-damaged glasses has led to the generally accepted conservative factor of about 10X enhanced dissolution rate due to radiation-induced changes in atomic structure of the glass. Studies with glass matrices are also cited in which no significant effects of radiation damage are observed. Similar corrosion testing of radiation-damaged crystalline ceramics has shown that increases in leach rates due to radiation-induced changes in ceramics can range from no significant effects, up to a factor of $10 \mathrm{X}$ to $100 \mathrm{X}$ enhanced dissolution rates. If one considers only heavyion bombardment techniques for simulating radiation damage from alpha recoil processes, a limited number of studies exist that are cited in recent review articles. (Note, however, that several other techniques have been employed for simulating radiation damage processes, such as actinide-doping, neutron irradiation, 
charged particle (electron, proton, alpha-particle), and gamma irradiation). Table 2 shows general conclusions from previous studies that involved heavy-ion irradiation (of both glass and crystalline materials) and corrosion testing. These studies indicate that enhanced dissolution rate from ion bombarded matrices can range from insignificant up to about $10 \mathrm{X}$ increase.

Table 2. Heavy Ion Irradiation Studies with Corrosion Testing

\begin{tabular}{|l|l|l|l|}
\hline Ion Source & Material & Conclusion & Reference \\
\hline $\mathrm{Pb}$ & Glass (Frit 131/TDS-3A) & $\begin{array}{l}\text { Leach rates not } \\
\text { significantly altered }\end{array}$ & Arnold et al., Ref. 12 \\
\hline $\mathrm{Pb}$ & $\begin{array}{l}\text { Crystalline ceramic titanate } \\
\left(55.5 \mathrm{TiO}_{2} / 19.5 \mathrm{CaO}+\text { minor }\right. \\
\text { components })\end{array}$ & $\begin{array}{l}\text { Did not result in } \\
\text { significant enhancement } \\
\text { of matrix dissolution } \\
\text { during leaching }\end{array}$ & Dosch et al., Ref. 9 \\
\hline $\mathrm{Bi}^{+}$ & Monazite $\left(\mathrm{LaPO}_{4}\right)$ & Leach rates remain low & Sales et al., Ref 13 \\
\hline $\mathrm{K}$ and $\mathrm{Rb}$ ions & $\mathrm{UO}_{2}$ & $\begin{array}{l}\text { Order of magnitude } \\
\text { increase }\end{array}$ & Matzke, Ref. 14 \\
\hline $\mathrm{Bi}^{2+}$ & $\begin{array}{l}\text { Sphene }\left(\mathrm{CaTi}\left(\mathrm{SiO}_{4}\right) \mathrm{O}\right) \\
\text { Sphene ceramics }\end{array}$ & Factor of 10X increase & Stevanovic et al., Ref. 15 \\
\hline
\end{tabular}

\section{B. Purpose}

The purpose of this study is to assess the effects of heavy-ion irradiation on the durability of pyrochlore-rich ceramics and single-phase pyrochlore, zirconolite, and brannerite ceramics. Ion irradiation of ceramic pellet surfaces will transform the outermost several tenths of microns of the surface into a metamict state.. Short-term monolithic leach tests on unirradiated and irradiated samples were used to elucidate any significant differences in the durability of the undamaged crystalline surface versus the damaged surface. Data developed under this task and reported in this report will be used in the preparation of a preliminary integrated data report to be supplied to the Office of Civilian Radioactive Waste Management (RW) in July of 1999 for use in license application for the candidate Yucca Mountain repository [2]. The preliminary integrated data report is planned to be updated by over the next two years as more ceramic corrosion data become available. This technical report supports the PIP WBS 2.4.1.1, Radiation-Damage Sample Synthesis milestone related to ion-irradiation study.

Disposition of plutonium using can-in-can technology will prepare immobilized ceramic plutonium waste forms that will eventually be qualified for a High-Level Waste (HLW) repository [2]. Accordingly, all work performed in this study by both SRTC and PNNL personnel has been conducted in compliance with the quality assurance requirements of DOE/RW-0333P $[16,17]$. 


\section{EXPERIMENTAL}

\section{A. Test Samples}

\section{PNNL-Fabricated Ceramics}

Preparation and characterization of the titanate-based ceramic materials used in this corrosion study have been described in detail by PNNL personnel. A report by D. M. Strachan of PNNL detailing these activities is included in Appendix A. Briefly, four different ceramic wafer samples were fabricated and cut into pellets. Fabrication was performed per the nominal baseline fabrication process described by Ebbinghaus [6]. The fabrication steps included powder batching, wet milling, calcining, and sintering. All samples were hot isostatically pressed (HIPed) $\left(1250^{\circ} \mathrm{C}\right.$ and $\left.170 \mathrm{MPa}(25,000 \mathrm{psi})\right)$ at Argonne National Laboratory (ANL) before sintering. Hot isostatic pressing is not routinely used in the baseline formulation process [6], but was used in the preparation of these samples to minimize porosity in the final product. Porosity was of concern because open porosity in the sample would represent "internal" surface area that was not radiation damaged. The area of the internal surfaces could exceed that of the external (geometric) surface, and because both types of surface would be exposed to the leaching solution, release from the internal surfaces could mask any enhanced dissolution occurring from the damaged outer surface.

The zirconolite and brannerite HIPed samples were core drilled and the resulting wafers were sintered at PNNL. The zirconolite wafers were sintered at $1400^{\circ} \mathrm{C}$ for $10 \mathrm{~h}$ and the brannerite wafers were sintered under pure flowing oxygen at $1330^{\circ} \mathrm{C}$ for $72 \mathrm{~h}$. The baseline material was core drilled from the HIPed sample and was not sintered due to the good density and phase assemblage of the HIPed sample. The pyrochlore material failed during hot pressing at ANL. Subsequent preparation of new pyrochlore samples did not receive hot isostatic pressing at ANL. These pyrochlore samples were prepared as individual pellets that received pressing and sintering at PNNL (70 Mpa $(10,000 \mathrm{psi})$ at $1350^{\circ} \mathrm{C}$ for 10 hours). The asbatched compositions, resulting densities, and $\mathrm{x}$-ray diffraction (XRD) patterns for all powdered ceramic samples are given in Appendix A.

All samples were polished with 600-grit $\mathrm{SiC}$ paper under water. Half of the samples were then irradiated at $50^{\circ} \mathrm{C}$ with $2 \mathrm{MeV} \mathrm{Au}{ }^{2+}$ ions over both surface areas that were nominally a total of $3.15 \mathrm{~cm}^{2}$. Both surface areas were irradiated (about 5.5 ions $/ \mathrm{nm}^{2}$ or $5.5 \times 10^{14}$ ions $/ \mathrm{cm}^{2}$ ) and the thin edges of the pellets were not irradiated. This total flux is estimated to have been roughly 2-4 times the amount needed to induce the crystalline to amorphous transition in the outer surface of the irradiated ceramics. For instance, Smith et al. have recently shown that crystalline pyrochlore and zirconolite become amorphous in the range of 3.5 to $4.3 \times 10^{14}$ ions $/ \mathrm{cm}^{2}$ dose using $1.5 \mathrm{MeV} \mathrm{Kr}{ }^{+}$ions at a flux of $\sim 3.4 \times 10^{14} \mathrm{ions} / \mathrm{cm}^{2} / \mathrm{s}$ [10]. PNNL scientist W. J. Weber estimated that the thickness of the amorphous layer produced by the $\mathrm{Au}^{2+}$ ion beam irradiations used in this study is about 0.3 microns on each surface of the nominally 1,000 -micron thick pellets. No experimental testing was conducted on the irradiated ceramics to determine the actual damage 
layer thickness. Samples were shipped to SRTC for corrosion testing after irradiation. The following total of thirty-six pellets were received for leach testing: A0 pyrochlore-rich baseline (three irradiated and unirradiated), single-phase B0-12 pyrochlore, B0-11 zirconolite and B0-13 brannerite (five irradiated and unirradiated of each nominally single-phase ceramic). These PNNL-fabricated ceramics all contained cerium as surrogate for both plutonium and uranium. Details of the various ceramic sample test matrices, referred to as Series A and Series B, can be found in Reference 6.

\section{SRTC-Fabricated Ceramics}

Preliminary leaching tests in support of this study were conducted on AO baseline, cerium-containing ceramics fabricated at SRTC. The purpose of these preliminary efforts was to investigate the leach test methodology and analytical methods to be eventually used on the irradiated and unirradiated PNNL fabricated samples. Details of the fabrication and properties of the SRTC fabricated ceramics are included in Appendix B. These ceramics all contained cerium as surrogate for both plutonium and uranium.

Comparison of the XRD spectra of cerium-containing, powdered A0 baseline ceramics from PNNL (see Appendix A, Attachment 5, 'HB6') and SRTC (see Appendix B, Figure B1) indicates good agreement in the crystalline phases identified. Pyrochlore $\left(\mathrm{X}_{2} \mathrm{Ti}_{2} \mathrm{O}_{7}\right)$ is identified as the major phase (see peaks at 2Theta(deg) of $15,31,35,39,47,51,61$ and 63). Minor amounts of both rutile $\left(\mathrm{TiO}_{2}\right.$ ) (see peaks at 2 Theta(deg) of 27, 36 and 55) and perovskite $\left(\mathrm{CaTiO}_{3}\right)$ (see peaks at 2-Theta(deg) of 33 and 47) were also identified.

\section{B. MCC-1 Leach Tests}

Leach tests were performed on monolithic ceramic pellets using the MCC-1 test that is described by the ASTM procedure C1220-92 [18]. This test is typically used to compare the corrosion behavior of different materials, and provides a measure of the initial dissolution rate of a material. Each ceramic pellet received from PNNL was cleaned in an ultrasonic bath of deionized water (DIW) and ethanol. The water used in these studies was ASTM-Type I purity ( $>18 \mathrm{Megaohm \bullet} \bullet \mathrm{cm}$ ) obtained from a MilliQ (Millipore filter) water purification system. The geometric surface area of each pellet was calculated from a measured diameter and thickness. These measurements were taken with electronic calipers upon receipt of the samples prior to ultrasonic cleaning. All stainless steel test vessels (Parr 304L, 22-mL) were cleaned by two successive boilings in $1 \% \mathrm{HNO}_{3}$ for one hour. All high-purity nitric acid used in this study contained less than $0.1 \mathrm{ppb}$ of trace contaminants as indicated from the 'Certificate of Analysis' received with the acid from the vendor. Vessels were then successively boiled in DIW two times. Vessels were then filled with DIW and sealed with Teflon gaskets and placed in constant-temperature oven at $90^{\circ} \mathrm{C}$ overnight. After cooling, the DIW was sampled for $\mathrm{pH}$ and analyzed for calcium. 
Leach tests were conducted by sealing a single ceramic pellet in a vessel with about $18 \mathrm{~g}$ of DIW. Considering all samples and blanks leach tested for this study, an average solution volume of $18.4 \pm 1.1 \mathrm{~mL}$ was used. Ceramic pellets were dried at $90^{\circ} \mathrm{C}$ after ultrasonic cleaning and weighed prior to contacting the leachate solution. The ceramic pellets rested on a stainless steel insert at the bottom of the vessel. These steel inserts were also cleaned using the same procedures as used for the leach vessels. Typically, at least two vessels containing only the leachate were tested as blanks along with each group of ceramic pellets. All test vessels, including the blanks, were placed in constant-temperature oven at $90^{\circ} \mathrm{C}$ for the appropriate time period. Oven temperatures were measured using a NIST-traceable calibrated resistance temperature device (RTD) and digital readout (John Fluke Mfg. Co, Inc. Digital Thermometry System). Temperature readings were automatically recorded every thirty minutes and the temperature was maintained at $90 \pm 1^{\circ} \mathrm{C}$ throughout each leach test duration. At the end of a test, samples were removed from the oven, cooled to ambient temperature, and an aliquot of each leachate was removed and analyzed for $\mathrm{pH}$. The remaining leachate solutions were transferred to plastic scintillation vials, acidified with about $0.2 \mathrm{~mL}$ of high purity $\mathrm{HNO}_{3}$ acid, and analyzed for elemental concentrations with inductively coupled plasma-mass spectrometry (ICP-MS) for all elements except calcium. Calcium was analyzed used ICP-Emission Spectroscopy (ICP-ES). The test vessels were then filled with $5 \% \mathrm{HNO}_{3}$ and placed in a $90^{\circ} \mathrm{C}$ oven overnight. These acid solutions, or "acid strips", were then analyzed to determine the amount of material that had become "fixed" on the vessel walls. The acid strip solutions were also analyzed by ICP-MS and ICP-ES.

Ceramic samples were initially removed from the leach vessels after contact times of 1,3 , or 7 days. Subsequent leaching of these same samples was performed after briefly rinsing the ceramic pellets with ASTM-I water for about one minute. The second round of tests used clean vessels and fresh ASTM-I leachate. This method of successive leaching of a single monolith with replenishment of the leachate has been previously performed in ion irradiation and corrosion tests on glass samples [12]. Preliminary calculations indicated that using a nominal normalized leach rate of about $0.3 \mathrm{~g} / \mathrm{m}^{2} /$ day at $90^{\circ} \mathrm{C}$ and a ceramic density of $5 \mathrm{~g} / \mathrm{cm}^{3}$, each ceramic surface would be depleted of about 0.06 microns of surface material per day. The leach rate of $0.3 \mathrm{~g} / \mathrm{m}^{2} /$ day was considered to be representative of a normalized mass loss leach rate for calcium from titanate ceramics (a pyrochlore-rich ceramic) [19].

\section{Analyses}

Sample analyses consisted of initial ICP-MS analysis for cations Ti, Ce, Gd and Hf, followed by ICP-ES analysis for $\mathrm{Ca}$ ion in the remaining leachate. The ICP-MS results were later reanalyzed to quantitatively estimate molybdenum in leachates for the PNNL-fabricated pyrochlore and zirconolite samples. Under oxidizing conditions, molybdenum likely exists as the molybdate anion $\left(\mathrm{MoO}_{4}{ }^{-} / \mathrm{Mo}_{2} \mathrm{O}_{7}{ }^{2-}\right)$ in solution, and would be quite soluble in the leachates, unlike most of the other elements present in the ceramic. Internal standards ( $\mathrm{In}, \mathrm{Bi}$, and $\mathrm{Sc}$ ) as well as standards containing the elements of interest ( $\mathrm{Ti}, \mathrm{Ce}, \mathrm{Gd}$, and $\mathrm{Hf}$ ) were added to all acidified leachates prior to ICP-MS analysis. These additions resulted in a very slight $(\sim 1 \%)$ 
dilution of leachates. Molybdenum concentrations were estimated using the following procedure. Response factors for both ${ }^{45} \mathrm{Sc}$ and ${ }^{115}$ In were established from the internal standards in the concentration range of 1-50 ppb. The response factor was then assumed to increase linearly from mass 45 to mass 115 . ICP-MS peak areas corresponding to molybdenum masses 92 through 100 in the leachate solutions were then converted to an estimated Mo concentration using the linear response equation derived from the internal standards.

Calibration data for ICP-MS were obtained over the concentration range of interest, typically $1-50 \mathrm{ppb}$, using stock solutions containing the internal standards and Ti, Ce, Gd, and Hf. Calibration data for ICP-ES were obtained using calcium-containing standards over the concentration range of 0.1 to $10 \mathrm{mg} / \mathrm{L}$. No internal standards were used in ICP-ES analyses. Minimum detection limits (mdl) of nominally $5 \mathrm{ppb}$ for ICP-ES analyzed calcium and $0.05 \mathrm{ppb}$ for ICP-MS analyzed elements were established throughout this work. These minimum detection limits were determined from consideration of data generated during analysis of all data sets. These values are operationally defined as the analyte concentration yielding an analytical signal equal to a confidence factor of ten times the standard deviation of the 'analytical' blank solution replicates [20]. The analytical blank solutions consisted of acidified ASTM-I water and were typically prepared by analytical development personnel at SRTC, i.e., the analytical blank solutions were not the same as the blank leachate solutions derived from MCC-1 testing. Triplicate blank analyses were routinely obtained during analysis of each ICP-ES and each ICP-MS sample sets.

All analytical standards used in this work were obtained from High-Purity Standards (HPS), Charleston, SC. All HPS standard solutions are certified against the National Institute of Standards and Technology (NIST), Office of Standard Reference Materials (OSRM) 3100 Series, Spectrometric Standard Solutions. A Certificate of Analysis ( $C$ of $A$ ) is included with each standard and all standards were used within the oneyear certified accuracy period.

\section{RESULTS AND DISCUSSION}

\section{A. Calcium Analysis and pH Testing of Cleaned Vessels}

Cleaning of stainless steel leach vessels involved successive boilings with 1 vol\% nitric acid and successive boilings with ASTM-I water. After these boilings, vessels were thoroughly rinsed with several volumes of ASTM-I water. These cleaned sample vessels were tested by filling them with ASTM-I water, sealing the vessels, and placing them in controlled, constant-temperature ovens overnight at $90^{\circ} \mathrm{C}$. Vessels were removed, cooled and the $\mathrm{pH}$ of the water determined. Residual water in the vessels was then analyzed for calcium by ICP-ES. Table 3 shows the average results of two batch cleanings of about thirty vessels each. Figures 1 and 2 show the histograms for calcium concentrations from these data sets. 
In Figures 1 and 2, $\mathrm{N}$ equals the number of vessels that have the respective range of calcium concentrations. Calcium levels in the water averaged 22 and $33 \mathrm{ppb}$ and average $\mathrm{pH}$ values were near 5.7. The calcium concentration of the ASTM-I water itself typically approached the instrumental minimum detection limit of about $5 \mathrm{ppb}$. Nitric acid was added at 1 vol\% to ASTM-I water as the initial cleaning step in all vessel cleanings, and vendor-supplied certified analyses of the nitric acid stock solution indicates less than $0.1 \mathrm{ppb}$ (or $<0.0001 \mathrm{ppm}$ ) of calcium in the high-purity acid stock used in the vessel cleaning. Initial water $\mathrm{pH}$ readings from six different measurements averaged $6.0 \pm 0.4$.

Uncertainty values $( \pm$ ) cited in Table 3 and elsewhere within this document when applied to experimental measurements refer to the 1 -sigma sample standard deviation, i.e., the $68 \%$ confidence level, for $\mathrm{N}$ results $\left(x_{i}\right)$ from multiple tests comprising the 'sample' set. This standard deviation, $\sigma$, is calculated from Equation 1 as:

$$
\sigma_{S}^{2}=\sum\left(x_{i}-<x>\right)^{2} /(N-1)
$$

\section{(Equation 1)}

where $\langle x>$ is the mean of the set.

The results in Table 3 indicate that cleaned steel vessels contain on average 4 to 6 times more calcium (20 to $30 \mathrm{ppb}$ ) than the pure ASTM-I water (5 ppb). The average $\mathrm{pH}$ values in Table 3 , when compared to initial $\mathrm{pH}$ values of water used to leach the cleaned vessels are within the error range of the initial starting water used to test the cleaned vessels.

Table 3. Average Calcium Analyses and pH Data from Leaching of Cleaned Vessels

\begin{tabular}{|c|c|c|c|}
\hline Cleaning Set & Total Vessels & Calcium (ppm) & $\mathrm{pH}^{*}$ \\
\hline$\# 1$ & 30. & $22 \pm 10$ & $5.6 \pm 0.4$ \\
\hline$\# 2$ & 29 & $33 \pm 17$ & $5.8 \pm 0.5$ \\
\hline
\end{tabular}

* Initial $\mathrm{pH}=6.0 \pm 0.4$ 
Figure 1. Histogram of Blank Ca Concentrations from Cleaned Vessels Set \#1

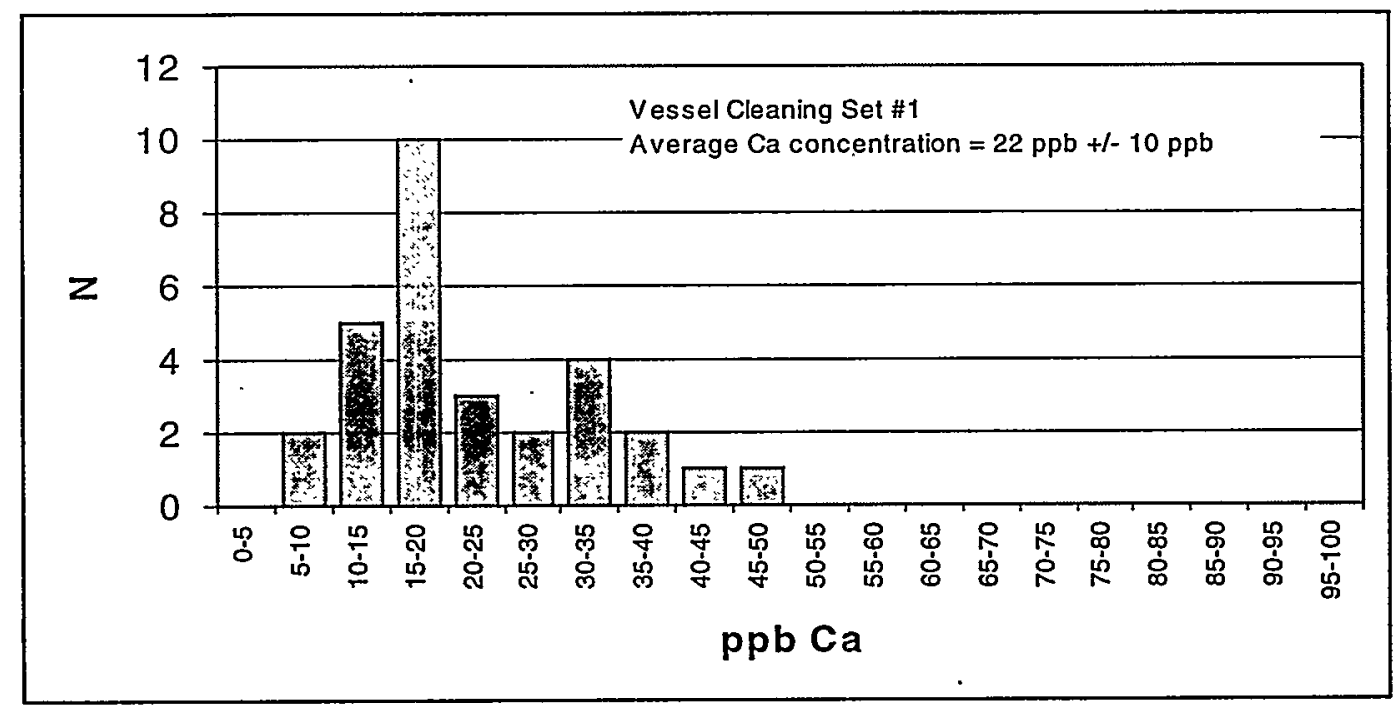

Figure 2. Histogram of Blank Ca Concentrations from Cleaned Vessels Set \#2

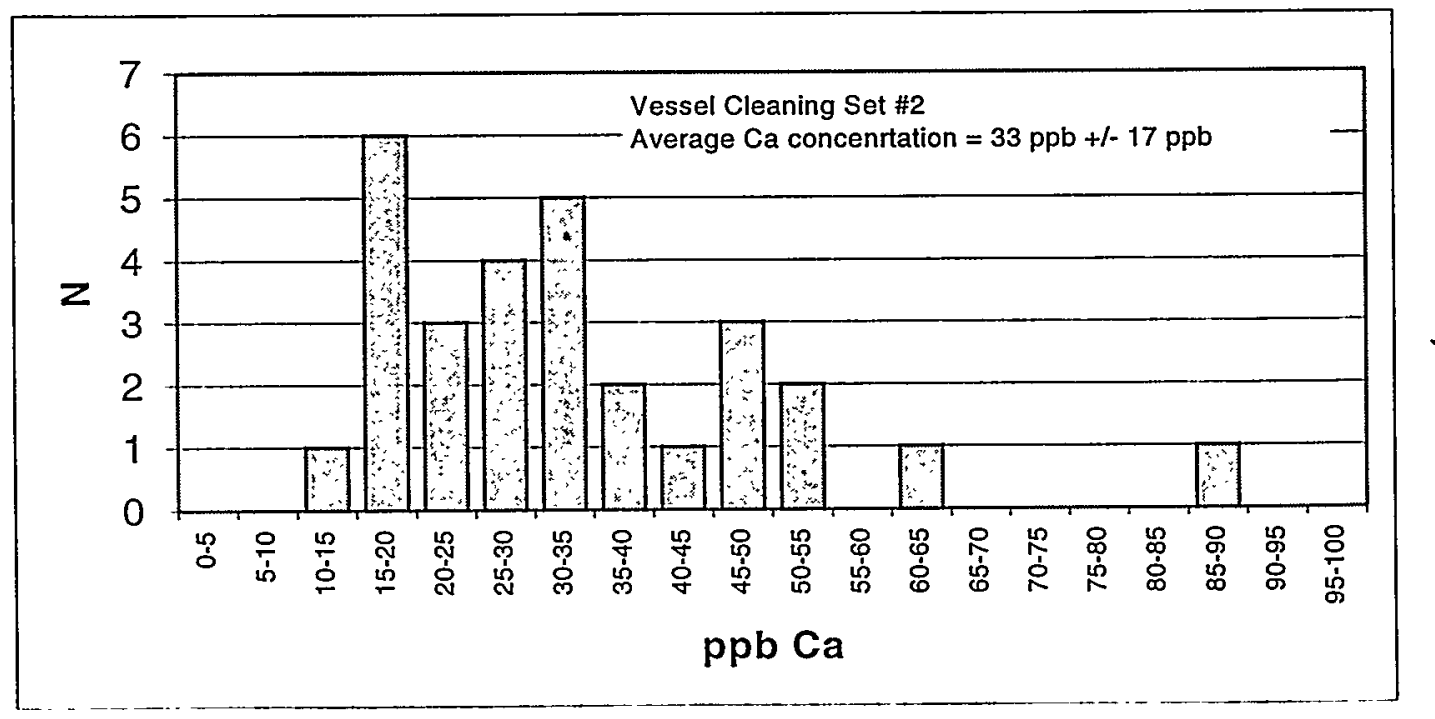




\section{B. Leach Tests with SRTC-Fabricated Baseline Ceramics}

SRTC-fabricated baseline A0 ceramics were leached in duplicate for one-day increments at $90^{\circ} \mathrm{C}$ for a total of four successive days. These two samples, samples 1 and 2, were then leached for a 3-day period.

Concurrent with these tests were a 3-day and subsequent 4-day leaching of another set of replicate samples, samples 3 and 4. A 7-day test was also performed concurrently on another replicate set of ceramic samples, samples 5 and 6 . Three different 1-day blank tests, a singe 3-day blank test and 2 different 7-day blank tests were also run. No blank tests were run for the 4-day tests. Table 4 shows the leaching sequence for the six ceramic samples and blanks tested.

Table 4. Leaching Sequence for One Week Testing of SRTC Baseline Samples

\begin{tabular}{|c|c|c|c|c|}
\hline Sample ID & 1-Day Tests & 3-Day Tests & 4-Day Tests & 7-Day Tests \\
\hline 1 & 4 consecutive & 1 & - & - \\
\hline 2 & 4 consecutive & 1 & - & - \\
\hline 3 & - & 1 & 1 & - \\
\hline 4 & - & 1 & 1 & - \\
\hline 5 & - & - & - & 1 \\
\hline 6 & - & - & - & 1 \\
\hline Blanks 1-3 & 1 & - & - & - \\
\hline Blank 4 & - & 1 & - & - \\
\hline Blanks 5-6 & - & - & - & 1. \\
\hline
\end{tabular}

The average surface dimensions for the six leached pellets were radius $=0.49 \mathrm{~cm}$ and thickness $=0.20 \mathrm{~cm}$, giving a total surface area of $2.17 \mathrm{~cm}^{2}$. The average bulk density measured for three pellets was $5.00+/-$ $0.21 \mathrm{~g} / \mathrm{cm}^{3}$. After completion of the leach tests, all leachates were acidified and analyzed. All leach vessels were then acidified and acid stripped overnight at $90^{\circ} \mathrm{C}$. Elemental analyses were then combined for both leachate and acid strip solutions. Total amounts of each element leached were calculated using the solution volumes and measured concentrations. Solution volumes for both the leachate and acid strip solutions were determined by mass difference. A density correction was used for the $5 \%$ acid strip solutions. Blank correction of both leachate and acid strip data was performed by subtracting the average concentration for replicate blanks from the sample leachate and acid strip values. All blank-corrected masses were then normalized to the geometric surface area of the ceramic, and normalized to the amount of each element in the ceramic matrix, using Equation 2 below. This result is referred to as the normalized mass loss (NL(i)).

$\mathrm{NL}(\mathrm{i})=\mathrm{m}_{\mathrm{i}} /\left[(\mathrm{SA}) * \mathrm{f}_{\mathrm{i}}\right]$

(Equation 2)

with: $\mathrm{NL}(\mathrm{i})=$ normalized mass loss for element $\mathrm{i},\left(\mathrm{g} / \mathrm{m}^{2}\right)$

$\mathrm{m}_{\mathrm{i}}=$ mass of element $\mathrm{i}$ released during test, $(\mathrm{g})$

$\mathrm{SA}=$ total surface area of exposed ceramic monolith, $\left(\mathrm{m}^{2}\right)$

$f_{i}=$ mass fraction of element $i$ in the ceramic 
The blank-corrected normalized losses $\left(\mathrm{g} / \mathrm{m}^{2}\right)$ based on $\mathrm{Ca}, \mathrm{Ti}, \mathrm{Ce}, \mathrm{Gd}$, and $\mathrm{Hf}$ are summarized in Table 5 for the leach tests performed on the SRTC AO baseline ceramic. Ranges of normalized release values are given for the replicate samples leached for $1,3,4$, and 7 days. The normalized releases were calculated from the sum of the blank-corrected leachate concentrations and the blank-corrected acid strip concentrations. Ranges of normalized release rates are also given in Table 5. The minimum detectable limit of normalized mass loss for all elements has been estimated from Equation 2 by using the instrumental minimum detection limits of $5 \mathrm{ppb}$ for calcium and $0.05 \mathrm{ppb}$ for other elements, an average solution volume of $18.4 \mathrm{~mL}$ for both ceramic leachate and acid strip samples, an average ceramic surface area of $2.17 \mathrm{~cm}^{2}$, and the mass fraction of each element for the $\mathrm{A} 0$ baseline ceramic. These minimum detectable limit normalized mass loss values are shown in the notes below Table 5. These values represent an accurate estimate of the minimum detectable corrosion that we were capable of measuring in these tests.

Appendix C (see Table C-1) contains the analytical data for calcium analysis from the 1-day leach tests. The data in Table C-1 of Appendix C shows that all the 1-day total calcium releases from both replicate pellets tested are above the average from three replicate blank tests. Thus these results help to confirm in our preliminary tests for this study, the viability of performing such relatively short term leaching tests on these type ceramics. Appendix $\mathrm{C}$ also contains analytical data from analysis for all elements from leachate and acid strip solutions along with the calculated normalized mass loss values for all elements (see Table C-2 of Appendix C).

All reported analytical concentration data for $\mathrm{Ca}, \mathrm{Ti}, \mathrm{Ce}, \mathrm{Gd}$ and $\mathrm{Hf}$ were above the instrument minimal detection limits for these elements. However, in some cases, blank correction of results gave negative values for mass amounts released (see data for $\mathrm{Ti}, \mathrm{Ce}, \mathrm{Gd}$ and $\mathrm{Hf}$ in Table 5). Blank correction involved subtracting an average value determined from replicate blanks from each individual leachate or acid strip concentration. When both the blank-corrected leachate mass release value and the blank-corrected acid strip mass release value were both negative, the overall corrected normalized loss NL(i) value is reported in Table 5 as ' 0.00 '. These NL(i) values are indicated in Table 5 with a double asterisk (**). For a statistical treatment of the results, one should refer to the complete analytical results (actual corrected normalized release values) that are given in Appendix $C$. When only one of the blank corrections, i.e., either leachate or acid strip solution, resulted in a negative value, this negative value was not used in calculating the blankcorrected normalized mass loss. The pH's of final leachate solutions were not obtained for the SRTC A0 dataset. 
The results summarized in Table 5 agree reasonably well with results obtained at ANL in similar tests $[19,21]$. A detailed comparison of normalized calcium mass loss data obtained in the present studies with ANL results follows later in Section $E$ of this report. Analysis of the data in Table 5 indicates that: 1) normalized release for calcium is higher than other elements, i.e., the ceramic dissolves incongruently; and 2) normalized calcium release data also shows as expected, more calcium is released in longer duration tests than shorter duration tests.

Incongruent dissolution has been noted previously by ANL in corrosion testing of zirconolite-rich ceramics and corrosion testing of pyrochlore-rich ceramics $[19,21]$. Two possible mechanisms were suggested for incongruent dissolution. One explanation is preferential leaching of a relatively leachable, calcium-bearing minor phase or phases. Perovskite $\left(\mathrm{CaTiO}_{3}\right)$ is one such mineral phase and it was identified by XRD as a minor/trace component in the SRTC-fabricated A0 Baseline sample (see Appendix B). Another explanation of higher release values for calcium relative to other matrix elements is relatively higher release of calcium from grain boundaries, i.e., calcium not present in a well-defined crystalline structure. A third explanation for the incongruent release is that some elements may be at or near saturation with respect to a solid phase. For instance, the $\mathrm{Ti}$ concentrations in solution may be limited by the solubility of a $\mathrm{TiO}_{2}$ phase (rutile or anatase). 
Table 5. Normalized Mass Loss (blank-corrected) from MCC-1 Tests at 1, 3,4 and 7-day Durations at $90^{\circ} \mathrm{C}$ with Duplicate Samples of SRTC A0 Baseline Ceramics Polished to 600 Grit

\begin{tabular}{|c|c|c|c|c|c|}
\hline Samples & Element & Replicates & $\begin{array}{c}\text { Test Duration } \\
\text { (days) }\end{array}$ & $\begin{array}{c}\text { *Range of NL(i) } \\
\left(\mathrm{g} / \mathrm{m}^{2}\right)\end{array}$ & $\begin{array}{c}\text { Range of NLR(i) } \\
\left(\mathrm{g} / \mathrm{m}^{2} / \mathrm{d}\right)\end{array}$ \\
\hline 1,2 & Calcium & 8 & 1 & $0.020-0.114$ & $0.020-0.114$ \\
\hline $1,2 \& 3,4$ & & 4 & 3 & $0.057-0.178$ & $0.019-0.059$ \\
\hline 3,4 & & 2 & 4 & $0.067-0.161$ & $0.017-0.040$ \\
\hline 5,6 & & 2 & 7 & $0.194-0.269$ & $0.028-0.039$ \\
\hline 1,2 & Titanium & 8 & 1 & $0.00-0.0091 * *$ & $0.00-0.0091 * *$ \\
\hline $1,2 \& 3,4$ & & 4 & 3 & $0.00-0.0040 * *$ & $0.00-0.0013^{* *}$ \\
\hline 3,4 & & 2 & 4 & $0.0016-0.0056$ & $0.0004-0.0014$ \\
\hline 5,6 & & 2 & 7 & $0.0019-0.012$ & $0.00027-0.0017$ \\
\hline 1,2 & Cerium & 8 & 1 & $0.00-0.021 * *$ & $0.00-0.021 * *$ \\
\hline $1,2 \& 3,4$ & & 4 & 3 & $0.00-0.0065^{* *}$ & $0.00-0.0022^{* * *}$ \\
\hline 3,4 & & 2 & 4 & $0.0023-0.013$ & $0.0005-0.0032$ \\
\hline 5,6 & & 2 & 7 & $0.00061-.0010$ & $0.00009-0.00014$ \\
\hline 1,2 & Gadolinium & 8 & 1 & $0.00-0.035 * *$ & $0.00-0.035^{* *}$ \\
\hline $1,2 \& 3,4$ & & 4 & 3 & $0.00-0.010 * *$ & $0.00-0.0033^{* *} *$ \\
\hline 3,4 & & 2 & 4 & $0.0095-0.016$ & $0.0024-0.004$ \\
\hline 5,6 & & 2 & 7 & $0.00086-0.012$ & $0.00012-0.0017$ \\
\hline 1,2 & Hafnium & 8 & 1 & $0.00-0.0015^{* *}$ & $0.00-0.0015^{* *}$ \\
\hline $1,2 \& 3,4$ & & 4 & 3 & $0.00-0.0023^{* *}$ & $0.00-0.00076 * *$ \\
\hline 3,4 & & 2 & 4 & $0.00068-0.0012$ & $0.00017-0.0003$ \\
\hline 5,6 & & 2 & 7 & $0.00048-0.0035$ & $0.00007-0.0005$ \\
\hline
\end{tabular}

* Lower limit normalized mass losses $\left(\mathrm{g} / \mathrm{m}^{2}\right)$ estimated from Equation 2 are:

$\mathrm{NL}(\mathrm{Ca})=0.01, \mathrm{NL}(\mathrm{Ti})=0.00004, \mathrm{NL}(\mathrm{Ce})=0.00003, \mathrm{NL}(\mathrm{Gd})=0.0001, \mathrm{NL}(\mathrm{Hf})=0.0001$. See text.

** Negative calculated normalized releases (i.e., cases in which the blank-corrected releases are less than zero) are presented in the summary Table 5 as ' 0.00 '. For a statistical treatment of the results, one should refer to the complete analytical results (actual corrected normalized release values) that are given in Appendix C. See text. 


\section{Leach Tests with Irradiated and Unirradiated PNNL-Fabricated Pyrochlore Single-Phase Ceramics}

\section{Single-Phase Pyrochlore Ceramic Leaching Data Set 1}

Irradiated and unirradiated PNNL-fabricated pyrochlore single-phase ceramics were each leached in duplicate for one-day increments at $90^{\circ} \mathrm{C}$ for a total of four successive days. A total of seven blank tests were also performed. The average surface dimensions for these pellets were radius $=0.53 \mathrm{~cm}$ and thickness $=0.13 \mathrm{~cm}$, giving a total surface area $=2.18 \mathrm{~cm}^{2}$. After completion of the leach tests, all leachates were acidified and analyzed. All leach vessels were then acidified and acid stripped overnight at $90^{\circ} \mathrm{C}$. The $\mathrm{pH}$ 's of final leachate solutions were not obtained for this initial pyrochlore data set.

Measured concentrations of calcium in the leachate and acid-strip solutions for both blank and sample tests are given in Table 6 . The calcium masses calculated from multiplying the analyzed concentrations by the solution volumes are also shown. Averages of total calcium masses shown at the bottom of Table 6 indicate that the average quantity of $\mathrm{Ca}$ present in the seven blank tests was 1.3 micrograms. This is in the range of the averages for the eight unirradiated (nonrad) and eight irradiated (rad) sample values (average total. calcium range $=1.0$ to 1.7 micrograms). Normalized releases for calcium calculated from the total amount of calcium released (and the total surface area of each individual pellet and the mass fraction of calcium present in the single-phase pyrochloreceramic) are shown in the last two columns of Table 6. Uncorrected normalized release values for calcium range from 0.04 to $0.28 \mathrm{~g} / \mathrm{m}^{2}$ for the nonrad and rad data sets. However, blank correction of the calcium data results in normalized calcium releases in the range of -0.06 to $0.18 \mathrm{~g} / \mathrm{m}^{2}$.

Note that blank correction of each individual sample results in negative values for over half (10 out of 16 ) of all normalized calcium release values shown in Table 6 . These negative values are highlighted in the table. Because a negative leach value is impossible for a leach test, these negative values indicate that the release of calcium from these ceramics is very low relative to in the quantity present in the blank. Both the corrected and uncorrected mass loss values indicate that the unirradiated and irradiated ceramics are leaching similarly, i.e., the tests did not detect an effect of the ion radiation.

Appendix D contains all analytical data for the leachate and acid strip solutions obtained from 1-day leaching of the pyrochlore samples. Normalized mass losses for all elements $\mathrm{Ca}, \mathrm{Ti}, \mathrm{Ce}, \mathrm{Gd}, \mathrm{Hf}$, and $\mathrm{Mo}$, obtained from blank-corrected data are also shown. In the acid strip solutions for samples and blanks, the Mo concentrations were high, typically 8-16 ppb (see Table D-1, Molybdenum Data in Appendix D). Thus it appears that the acid is leaching Mo from the vessels. Consequently, the normalized release for molybdenum considers only blank-corrected leachate data (and not the acid strip solution data). This is not likely to be a problem because the molybdate anion is not expected to sorb strongly onto the walls of the vessel, and nearly all the molybdenum released from the ceramic should remain in the leachate. Average 
values for normalized mass losses based on $\mathrm{Ti}, \mathrm{Ce}, \mathrm{Gd}$, and Hf were typically less than $0.01 \mathrm{~g} / \mathrm{m}^{2}$.

Normalized mass losses for molybdenum were comparable to some of the normalized mass losses for calcium $\left(\leq 0.02 \mathrm{~g} / \mathrm{m}^{2}\right)$, even though molybdenum is present in the ceramic matrix at $0.1 \mathrm{wt} \%$ oxide $\left(\mathrm{MoO}_{3}\right)$ versus the much higher level of calcium $(8.2 \mathrm{wt} \% \mathrm{CaO})$. 
Table 6. Measured Concentrations and Normalized Mass Losses for Calcium from Four Successive 1-Day Leach Tests at $90^{\circ} \mathrm{C}$ with Duplicate Samples of Unirradiated and Irradiated SinglePhase Pyrochlore Ceramics Polished to 600 Grit (Data Set 1)

Mass $\mathrm{Ca}$ in Leachate (L) and Acid Strip (AS)- micrograms Ca

Concentration $\mathrm{Ca}$ in Leachate and Acid Strip - mg/L

\begin{tabular}{|c|c|c|c|c|c|c|c|}
\hline $\begin{array}{c}\text { Unirradiate } \\
\text { Time } \\
\text { (days) }\end{array}$ & $\begin{array}{l}\frac{t 1}{\text { Nonrad } 1} \\
L(\mu \mathrm{g})\end{array}$ & $\begin{array}{c}\text { Leachate } \\
\text { Concentration } \\
(\mathrm{mg} / \mathrm{L})\end{array}$ & $\begin{array}{c}\text { Nonrad } 1 \\
\text { AS }(\mu \mathrm{g})\end{array}$ & $\begin{array}{c}\text { Acid Strip } \\
\text { Concentration } \\
(\mathrm{mg} / \mathrm{L})\end{array}$ & $\begin{array}{c}\text { Total Mass } \\
(\mu \mathrm{g})\end{array}$ & $\begin{array}{c}\text { Uncorrected } \\
\mathrm{NL}(\mathrm{Ca}) \\
\left(\mathrm{g} / \mathrm{m}^{2}\right)\end{array}$ & $\begin{array}{c}\text { Corrected } \\
\mathrm{NL}(\mathrm{Ca}) \\
\left(\mathrm{g} / \mathrm{m}^{2}\right)\end{array}$ \\
\hline $1^{s t}$ & 0.8 & 0.046 & 2.7 & 0.151 & 3.5 & 0.275 & 0.176 \\
\hline $2^{\text {nd }}$ & 0.8 & 0.042 & 0.4 & 0.025 & 1.2 & 0.095 & 0.005 \\
\hline $3^{\text {rd }}$ & 0.6 & 0.032 & 1.1 & 0.065 & 1.7 & 0.134 & 0.034 \\
\hline $4^{\text {th }}$ & 0.7 & 0.037 & 0.1 & 0.005 & 0.8 & 0.062 & -0.038 \\
\hline \multicolumn{2}{|c|}{ Unirradiated Pellet 2} & Leachate & & Acid Strip & & Uncorrected & Corrected \\
\hline $\begin{array}{l}\text { Time } \\
\text { (days) }\end{array}$ & $\begin{array}{c}\text { Nonrad } 2 \\
L(\mu g)\end{array}$ & $\begin{array}{c}\text { Concentration } \\
(\mathrm{mg} / \mathrm{L})\end{array}$ & $\begin{array}{c}\text { Nonrad } 2 \\
\text { AS }(\mu \mathrm{g})\end{array}$ & $\begin{array}{c}\text { Concentration } \\
(\mathrm{mg} / \mathrm{L})\end{array}$ & $\begin{array}{c}\text { Total Mass } \\
(\mu \mathrm{g})\end{array}$ & $\begin{array}{c}\mathrm{NL}(\mathrm{Ca}) \\
\left(\mathrm{g} / \mathrm{m}^{2}\right)\end{array}$ & $\begin{array}{c}\mathrm{NL}(\mathrm{Ca}) \\
\left(\mathrm{g} / \mathrm{m}^{2}\right)\end{array}$ \\
\hline $1^{\text {st }}$ & 0.8 & 0.044 & 0.1 & 0.005 & 0.9 & 0.074 & -0.028 \\
\hline $2^{\text {nd }}$ & 0.6 & 0.032 & 0.5 & 0.027 & 1.1 & 0.087 & $0.015,3$ \\
\hline $3^{\text {rd }}$ & 0.4 & 0.024 & 1.2 & 0.075 & 1.6 & 0.128 & 0.026 \\
\hline $4^{\text {th }}$ & 1.2 & 0.065 & 1.2 & 0.070 & 2.4 & 0.194 & 0.092 \\
\hline \multicolumn{2}{|c|}{ Irradiated Pellet 1} & Leachate & & Acid Strip & & Uncorrected & Corrected \\
\hline $\begin{array}{c}\text { Time } \\
\text { (days) }\end{array}$ & $\begin{array}{l}\operatorname{Rad} 1 \\
L(\mu g)\end{array}$ & $\begin{array}{c}\text { Concentration } \\
\text { (mg/L) }\end{array}$ & $\begin{array}{c}\text { Rad } 1 \\
\text { AS }(\mu \mathrm{g})\end{array}$ & $\begin{array}{c}\text { Concentration } \\
(\mathrm{mg} / \mathrm{L})\end{array}$ & $\begin{array}{c}\text { Total Mass } \\
(\mu \mathrm{g})\end{array}$ & $\begin{array}{c}N L(\mathrm{Ca}) \\
\left(\mathrm{g} / \mathrm{m}^{2}\right)\end{array}$ & $\begin{array}{c}\mathrm{NL}(\mathrm{Ca}) \\
\left(\mathrm{g} / \mathrm{m}^{2}\right)\end{array}$ \\
\hline $1^{s t}$ & 0.6 & 0.031 & 1.0 & 0.061 & 1.6 & 0.124 & 0.024 \\
\hline $2^{\text {nd }}$ & 0.6 & 0.031 & 0.8 & 0.051 & 0.9 & 0.068 & -0.032 \\
\hline $3^{\text {rd }}$ & 0.4 & 0.024 & 0.4 & 0.023 & 0.8 & 0.065 & -0.035 \\
\hline $4^{\text {th }}$ & 0.5 & 0.026 & 1.0 & 0.059 & 1.5 & 0.113 & 0.014 \\
\hline \multicolumn{2}{|c|}{ Irradiated Pellet 2} & Leachate & & Acid Strip & & Uncorrected & Corrected \\
\hline $\begin{array}{c}\text { Time } \\
\text { (days) }\end{array}$ & $\begin{array}{l}\operatorname{Rad} 2 \\
\mathrm{~L}(\mu \mathrm{g})\end{array}$ & $\begin{array}{c}\text { Concentration } \\
(\mathrm{mg} / \mathrm{L})\end{array}$ & $\begin{array}{r}\operatorname{Rad} 2 \\
\operatorname{AS}(\mu \mathrm{g}) \\
\end{array}$ & $\begin{array}{c}\text { Concentration } \\
(\mathrm{mg} / \mathrm{L})\end{array}$ & $\begin{array}{c}\text { Total Mass } \\
(\mu \mathrm{g})\end{array}$ & $\begin{array}{l}\mathrm{NL}(\mathrm{Ca}) \\
\left(\mathrm{g} / \mathrm{m}^{2}\right) \\
\end{array}$ & $\begin{array}{l}\mathrm{NL}(\mathrm{Ca}) \\
\left(\mathrm{g} / \mathrm{m}^{2}\right) \\
\end{array}$ \\
\hline $1^{\text {st }}$ & 0.1 & 0.003 & 0.8 & 0.051 & 0.9 & 0.068 & -0.032 \\
\hline $2^{\text {nd }}$ & 0.3 & 0.019 & 0.7 & 0.042 & 0.8 & 0.059 & -0.041 \\
\hline $3^{\text {rd }}$ & 0.4 & 0.022 & 0.1 & 0.005 & 0.5 & 0.038 & -0.062 \\
\hline $4^{\text {th }}$ & 0.5 & 0.025 & 0.6 & 0.039 & 1.1 & 0.087 & -0.013 \\
\hline
\end{tabular}


Table 6.

Continued

\begin{tabular}{c|ccccc}
$\begin{array}{c}\text { Blanks } \\
\begin{array}{c}\text { Time } \\
\text { (days) }\end{array}\end{array}$ & $\begin{array}{c}\text { Blanks } \\
\mathrm{L}(\mu \mathrm{g})\end{array}$ & $\begin{array}{c}\text { Leachate } \\
\text { Concentration } \\
(\mathrm{mg} / \mathrm{L})\end{array}$ & $\begin{array}{c}\text { Blanks } \\
\text { AS }(\mu \mathrm{g})\end{array}$ & $\begin{array}{c}\text { Acid Strip } \\
\text { Concentration } \\
(\mathrm{mg} / \mathrm{L})\end{array}$ & $\begin{array}{c}\text { Total Mass } \\
(\mu \mathrm{g})\end{array}$ \\
\hline 1 & 0.4 & 0.023 & 0.5 & 0.029 & 0.9 \\
1 & 0.5 & 0.024 & 0.9 & 0.054 & 1.4 \\
1 & 0.2 & 0.009 & 0.7 & 0.040 & 0.8 \\
1 & 0.4 & 0.020 & 1.7 & 0.097 & 2.1 \\
1 & 0.7 & 0.033 & 0.6 & 0.037 & 1.3 \\
1 & 0.3 & 0.017 & 0.6 & 0.035 & 0.9 \\
1 & 0.6 & 0.029 & 1.0 & 0.066 & 1.6
\end{tabular}

\begin{tabular}{|ccccc|}
\hline $\begin{array}{c}\text { * Total Mass Calcium Data: } \\
\text { (micrograms) }\end{array}$ & & & \\
& & & & \\
All 8 Tests & Nonrad & 1.7 & 0.9 & 55 \\
& & & & \\
All 8 Tests & Rad & 1.0 & 0.4 & 37 \\
All 7 Tests & Blanks & 1.3 & 0.4 & 34 \\
\hline
\end{tabular}

* Total mass calcium detectable at minimum detection limit of $\approx 5 \mathrm{ppb}$ equal to: $0.018 \mathrm{~L} \times 5 \mu \mathrm{g} / \mathrm{L} \approx 0.1$ micrograms

\section{Single-Phase Pyrochlore Ceramic Leaching Data Set 2}

Longer-term leach tests, Data Set 2, were performed on the pyrochlore ceramics after the Data Set 1 successive single day leach tests were completed. Irradiated and unirradiated PNNL-fabricated singlephase pyrochlore ceramics were each leached in duplicate for a 3-day increment at $90^{\circ} \mathrm{C}$ followed by a 7-day test at $90^{\circ} \mathrm{C}$. Six blank samples were included for each 3-day and 7-day test. All of the leachates from the blanks were analyzed. However, only two blank vessels from each of the six-set leachate blanks (3-day and 7-day) were acid stripped and analyzed. One of these 3-day acid strip solutions was highly contaminated as evidenced by extraordinarily large recovered values for $\mathrm{Ca}$, Ti and $\mathrm{Ce}$. This particular blank sample was thus not used in blank correction of any of the three-day acid strip data. All ceramic samples were ultrasonically cleaned with alcohol and water after the first round of tests and before starting the tests for Data Set 2. 
Measured concentrations of calcium from leachate and acid strip solutions from both the sample and blank leachates tests are given in Table 7. The average initial and final $\mathrm{pH}$ 's of the leachate solutions are also shown. Averages of total calcium masses shown in Table 7 indicate that the average blank response of 1.7 micrograms of calcium (3-day) is in the range of the average releases from the unirradiated and irradiated samples leached for 3 days ( 0.8 and 1.6 micrograms calcium). The average blank response of 0.8 micrograms calcium (7-day) is in the range of the averages for the unirradiated and irradiated samples leached for 7 days (1.2 and 0.8 micrograms calcium). Final $\mathrm{pH}$ values determined for all ceramic and blank samples were within about $0.5 \mathrm{pH}$ units from the starting $\mathrm{pH}$ of the ASTM-I water used to leach the ceramics.

Normalized mass loss values for calcium calculated from the total amount of calcium released (and the total surface area of each individual pellet and the mass fraction of calcium present in the single-phase pyrochlore ceramic) are shown in the last two columns of Table 7. Uncorrected normalized release values for calcium range from 0.04 to $0.16 \mathrm{~g} / \mathrm{m}^{2}$ for the nonrad and rad data sets. However, blank correction of the calcium data results in normalized calcium releases in the range of -0.08 to $0.038 \mathrm{~g} / \mathrm{m}^{2}$. Appendix D contains analytical data obtained from leaching of the pyrochlore samples for 3 and 7 days.

Blank-corrected normalized mass loss data for $\mathrm{Ca}, \mathrm{Ti}, \mathrm{Ce}, \mathrm{Gd}$, and $\mathrm{Hf}$ are also presented. As in previous short-term leach tests with the single-phase pyrochlore samples, the acid strip solutions for both samples · and blanks had nearly equal and relatively high concentrations of Mo. In the acid strip solutions for samples and blanks, the Mo concentrations ranged from 7-12 ppb (see Table D-2, Molybdenum Data in Appendix D). Consequently, the normalized release for molybdenum considers only sample and blank leachate data (and not the acid strip solutions). Average values for normalized releases for $\mathrm{Ti}, \mathrm{Ce}, \mathrm{Gd}$, and Hf were typically less than $0.01 \mathrm{~g} / \mathrm{m}^{2}$. Normalized mass losses for molybdenum were scattered. The $\mathrm{NL}(\mathrm{Mo})$ values ranged from negative values up to as high as $0.14 \mathrm{~g} / \mathrm{m}^{2}$. 
Table 7. Measured Concentrations and Normalized Mass Losses for Calcium from 3-Day and 7-Day MCC-1 Tests at $90^{\circ} \mathrm{C}$ with Duplicate Samples of Unirradiated and Irradiated Single-Phase Pyrochlore Ceramics Polished to 600 Grit, Data Set 2

Mass $\mathrm{Ca}$ in Leachate (L) and Acid Strip (AS)- micrograms Ca

Concentration $\mathrm{Ca}$ in Leachate and Acid Strip - $\mathrm{mg} / \mathrm{L}$

\begin{tabular}{|c|c|c|c|c|c|c|c|}
\hline \multicolumn{2}{|c|}{ Unirradiated Pellet 1} & \multirow{2}{*}{$\begin{array}{c}\text { Leachate } \\
\text { Concentration } \\
(\mathrm{mg} / \mathrm{L})\end{array}$} & \multirow[b]{2}{*}{$\begin{array}{c}\text { Nonrad } 1 \\
\text { AS }(\mu \mathrm{g})\end{array}$} & \multirow{2}{*}{$\begin{array}{c}\text { Acid Strip } \\
\text { Concentration } \\
(\mathrm{mg} / \mathrm{L})\end{array}$} & \multirow[b]{2}{*}{$\begin{array}{c}\text { Total Mass } \\
(\mu \mathrm{g})\end{array}$} & \multirow{2}{*}{$\begin{array}{l}\text { Uncorrected } \\
\text { NL(Ca) } \\
\left(\mathrm{g} / \mathrm{m}^{2}\right)\end{array}$} & \multirow{2}{*}{$\begin{array}{c}\text { Corrected } \\
\text { NL(Ca) } \\
\left(\mathrm{g} / \mathrm{m}^{2}\right)\end{array}$} \\
\hline $\begin{array}{c}\text { Time } \\
\text { (days) }\end{array}$ & $\begin{array}{c}\text { Nonrad } 1 \\
L(\mu \mathrm{g})\end{array}$ & & & & & & \\
\hline 3 & 0.6 & 0.031 & 1.5 & 0.087 & 2.1 & 0.164 & 0.033 \\
\hline 7 & 0.4 & 0.023 & 0.8 & 0.049 & 1.3 & 0.098 & 0.038 \\
\hline
\end{tabular}

\begin{tabular}{|c|c|c|c|c|c|c|c|}
\hline \multicolumn{2}{|c|}{ Unirradiated Pellet 2} & \multirow{2}{*}{$\begin{array}{c}\text { Leachate } \\
\text { Concentration } \\
(\mathrm{mg} / \mathrm{L})\end{array}$} & \multirow[b]{2}{*}{$\begin{array}{c}\text { Nonrad } 2 \\
\text { AS }(\mu \mathrm{g})\end{array}$} & \multirow{2}{*}{$\begin{array}{c}\text { Acid Strip } \\
\text { Concentration } \\
(\mathrm{mg} / \mathrm{L})\end{array}$} & \multirow[b]{2}{*}{$\begin{array}{c}\text { Total Mass } \\
(\mu \mathrm{g})\end{array}$} & \multirow{2}{*}{$\begin{array}{l}\text { Uncorrected } \\
\text { NL(Ca) } \\
\left(\mathrm{g} / \mathrm{m}^{2}\right)\end{array}$} & \multirow{2}{*}{$\begin{array}{c}\text { Corrected } \\
\text { NL(Ca) } \\
\left(\mathrm{g} / \mathrm{m}^{2}\right) \\
\end{array}$} \\
\hline $\begin{array}{l}\text { Time } \\
\text { (days) }\end{array}$ & $\begin{array}{c}\text { Nonrad } 2 \\
L(\mu \mathrm{g})\end{array}$ & & & & & & \\
\hline 3 & 0.2 & 0.008 & 1.0 & 0.061 & 1.2 & 0.095 & -0.039 \\
\hline 7 & 0.2 & 0.012 & 0.9 & 0.050 & 1.1 & 0.087 & 0.026 \\
\hline
\end{tabular}

\begin{tabular}{|c|c|c|c|c|c|c|c|}
\hline $\begin{array}{c}\text { Irradiated Pellet } 1 \\
\text { Time } \\
\text { (days) }\end{array}$ & $\begin{array}{l}\operatorname{Rad} 1 \\
L(\mu g)\end{array}$ & $\begin{array}{c}\text { Leachate } \\
\text { Concentration } \\
\text { (mg/L) }\end{array}$ & $\begin{array}{l}\text { Rad } 1 \\
\text { AS }(\mu \mathrm{g})\end{array}$ & $\begin{array}{c}\text { Acid Strip } \\
\text { Concentration } \\
(\mathrm{mg} / \mathrm{L})\end{array}$ & $\begin{array}{c}\text { Total Mass } \\
(\mu \mathrm{g})\end{array}$ & $\begin{array}{l}\text { Uncorrected } \\
\text { NL(Ca) } \\
\left(\mathrm{g} / \mathrm{m}^{2}\right)\end{array}$ & $\begin{array}{c}\text { Corrected } \\
\text { NL(Ca) } \\
\left(\mathrm{g} / \mathrm{m}^{2}\right)\end{array}$ \\
\hline 3 & 0.3 & 0.017 & $\overline{0.3}$ & 0.017 & 0.6 & 0.048 & $-0.083^{x}$ \\
\hline 7 & 0.2 & 0.012 & 0.7 & 0.044 & 0.9 & 0.074 & 0.015 \\
\hline
\end{tabular}

\begin{tabular}{|c|c|c|c|c|c|c|c|}
\hline $\begin{array}{c}\text { Irradiated Pellet } 2 \\
\text { Time } \\
\text { (days) }\end{array}$ & $\begin{array}{l}\operatorname{Rad} 2 \\
L(\mu g)\end{array}$ & $\begin{array}{c}\text { Leachate } \\
\text { Concentration } \\
(\mathrm{mg} / \mathrm{L})\end{array}$ & $\begin{array}{c}\operatorname{Rad} 2 \\
\text { AS }(\mu \mathrm{g})\end{array}$ & $\begin{array}{c}\text { Acid Strip } \\
\text { Concentration } \\
(\mathrm{mg} / \mathrm{L})\end{array}$ & $\begin{array}{c}\text { Total Mass } \\
(\mu \mathrm{g})\end{array}$ & $\begin{array}{c}\text { Uncorrected } \\
\mathrm{NL}(\mathrm{Ca}) \\
\left(\mathrm{g} / \mathrm{m}^{2}\right) \\
\end{array}$ & $\begin{array}{c}\text { Corrected } \\
\mathrm{NL}(\mathrm{Ca}) \\
\left(\mathrm{g} / \mathrm{m}^{2}\right) \\
\end{array}$ \\
\hline 3 & 0.2 & 0.008 & 0.8 & 0.049 & 0.9 & 0.073 & 0.058 \\
\hline 7 & 0.2 & 0.011 & 0.5 & 0.029 & 0.6 & 0.042 & 70.003 \\
\hline
\end{tabular}




\begin{tabular}{|c|c|c|c|c|c|}
\hline $\begin{array}{c}\text { Blanks } \\
\text { Time } \\
\text { (days) }\end{array}$ & $L(\mu g)$ & $\begin{array}{c}\text { Leachate } \\
\text { Concentration } \\
\text { (mg/L) }\end{array}$ & AS $(\mu \mathrm{g})$ & $\begin{array}{c}\text { Acid Strip } \\
\text { Concentration } \\
(\mathrm{mg} / \mathrm{L})\end{array}$ & $\begin{array}{c}\text { Total Mass } \\
(\mu \mathrm{g})\end{array}$ \\
\hline 3 & 0.4 & 0.022 & & & \\
\hline 3 & 0.3 & 0.013 & 1.4 & 0.085 & 1.6 \\
\hline 3 & 0.2 & 0.009 & & & \\
\hline 3 & 0.4 & 0.021 & & & \\
\hline 3 & 0.4 & 0.021 & & & \\
\hline 3 & 0.2 & 0.012 & & & \\
\hline Blanks & & Leachate & & Acid Strip & \\
\hline $\begin{array}{c}\text { Time } \\
\text { (days) }\end{array}$ & $\begin{array}{l}\text { Blanks } \\
L(\mu g)\end{array}$ & $\begin{array}{c}\text { Concentration } \\
(\mathrm{mg} / \mathrm{L})\end{array}$ & AS $(\mu \mathrm{g})$ & $\begin{array}{c}\text { Concentration } \\
(\mathrm{mg} / \mathrm{L})\end{array}$ & $\begin{array}{l}\text { Total Mass } \\
(\mu \mathrm{g})\end{array}$ \\
\hline 7 & 0.2 & 0.011 & 0.4 & 0.028 & 0.6 \\
\hline 7 & 0.3 & 0.014 & 0.7 & 0.041 & 1.0 \\
\hline 7 & 0.3 & 0.017 & & & \\
\hline 7 & 0.1 & 0.006 & & & \\
\hline 7 & 0.2 & 0.011 & & & \\
\hline 7 & 0.1 & 0.006 & & & \\
\hline
\end{tabular}

\begin{tabular}{|c|c|c|c|c|c|c|c|}
\hline \multicolumn{8}{|c|}{$\begin{array}{l}\text { Total Calcium Mass Data * } \\
\text { (micrograms): }\end{array}$} \\
\hline 3 Day: & Average & Std. Dev. & \%RSD & 7 Day: & Average & Std. Dev. & \%RSD \\
\hline Nonrad & 1.6 & 0.6 & 39 & Nonrad & 1.2 & 0.1 & 10 \\
\hline Rad & 0.8 & 0.2 & 29 & $\operatorname{Rad}$ & 0.7 & 0.3 & 38 \\
\hline Blanks & & & & Blanks & & & \\
\hline (Leachate) $^{a}$ & 0.3 & 0.1 & 35 & (Leachate) ${ }^{a}$ & 0.2 & 0.1 & 43 \\
\hline (Acid strip) $^{b}$ & 1.4 & -- & -- & (Acid strip) $^{c}$ & 0.6 & 0.2 & 32 \\
\hline Total & 1.7 & .- & -- & Total & 0.8 & 0.2 & 28 \\
\hline
\end{tabular}

* Total mass calcium detectable at minimum detection limit of $\approx 5 \mathrm{ppb}$ equal to: $0.018 \mathrm{~L} \times 5 \mu \mathrm{g} / \mathrm{L} \approx 0.1$ micrograms

a) Average of six blanks

b) Result of one acid strip

c) Average of two acid strip blanks

\begin{tabular}{|cccc|}
\hline pH Data & Replicates & $\begin{array}{c}\text { Final** } \\
\mathrm{pH}\end{array}$ & $\begin{array}{c}\text { Test } \\
\text { Duration } \\
\text { (days) }\end{array}$ \\
Nata Set 2 & 2 & $6.2 \pm 0.2$ & 3 \\
Nonrad 1\&2 & 2 & $6.0 \pm 0.0$ & 3 \\
Nonrad 1\&2 & 2 & $6.2 \pm 0.5$ & 7 \\
Rad 1\&2 & 2 & $5.8 \pm 0.4$ & 7 \\
\hline
\end{tabular}

** Initial $\mathrm{pH}$ value for 3 -day tests $=6.2$; Final $\mathrm{pH}$ values for 3-day blanks ( 6 samples $)=5.8 \pm 0.2$; Initial $\mathrm{pH}$ value for 7-day tests $=6.0$; Final $\mathrm{pH}$ values for 7-day blanks ( 6 samples $)=5.4 \pm 0.2$ 
It is difficult to draw clear and definitive conclusions from the data we have obtained on the leaching of irradiated (rad) and unirradiated (nonrad) pyrochlore ceramics because of the high durability of the ceramic and blank concentrations that are high relative to the quantity of material released from the ceramic in a test. It is clear that for both of these data sets, the concentrations of the leached elements were in many cases similar to or in some cases less than the concentrations obtained by averaging replicate data from blank tests containing no ceramics. At best, it can be said that the results on both irradiated and unirradiated samples indicate very low normalized mass losses and that ion bombardment of the surface did not significantly increase these low values.

Blank-corrected data shows normalized calcium mass losses in the range of 0.026 to $0.176 \mathrm{~g} / \mathrm{m}^{2}$ for unirradiated 1-day tests versus normalized calcium loss of $0.014 \mathrm{~g} / \mathrm{m}^{2}$ for irradiated 1-day tests. It is likely that the value of $0.176 \mathrm{~g} / \mathrm{m}^{2}$ (in Table 6) could be inaccurate due to an unexplained high value for calcium concentration in the acid strip solution in that test. Neglecting this single value for the 1-day unirradiated ceramic tests gives a normalized calcium mass loss in the range of only 0.026 to $0.092 \mathrm{~g} / \mathrm{m}^{2}$ for the unirradiated samples. Similar comparisons of blank-corrected, normalized calcium mass losses from Table 7 indicate that longer term 3 and 7-day leach tests show normalized calcium mass loss in the range of 0.026 to $0.038 \mathrm{~g} / \mathrm{m}^{2}$ for unirradiated tests and a $0.015 \mathrm{~g} / \mathrm{m}^{2}$ single positive value for irradiated tests.

\section{Leach Tests with Irradiated and Unirradiated PNNL Single-Phase Zirconolite Ceramics}

Duplicate samples of irradiated and unirradiated PNNL-fabricated zirconolite single-phase ceramics were each leached in a similar manner to the Data Set 2 pyrochlore samples discussed above. Irradiated and unirradiated PNNL-fabricated single-phase zirconolite ceramics were each leached in duplicate for 3 days followed by a 7-day test, both at $90^{\circ} \mathrm{C}$. Three blank tests were performed concurrently for the 3-day tests and four blank tests were performed concurrently for the 7-day test.

Measured concentrations of calcium from sample and blank leachates and sample and blank acid strip solutions are shown in Table 8. The average initial and final pH's of leachate solutions are also shown. Averages of total calcium masses shown at the bottom of Table 8 indicate that the average blank response of 0.5 micrograms calcium was less than either the nonrad or rad average total calcium $(0.8$ and 1.8 micrograms calcium, respectively) for all 3-day tests. Similarly, the average blank response of 1.0 micrograms calcium was less than either the nonrad or rad average total calcium (1.5 and 2.2 micrograms calcium, respectively) for all 7-day tests. Final $\mathrm{pH}$ values determined for all ceramic and blank samples were within about $0.7 \mathrm{pH}$ units from the starting $\mathrm{pH}$ of the ASTM-I water used to leach the ceramics.

Normalized mass loss values for calcium calculated from the total amount of calcium released (and the total surface area of each individual pellet and the mass fraction of calcium present in the single-phase 
zirconolite ceramic) are shown in the last two columns of Table 8. Uncorrected normalized release values for calcium range from 0.021 to $0.12 \mathrm{~g} / \mathrm{m}^{2}$ for the nonrad and rad data sets. However, blank correction of the calcium data results in normalized calcium.releases in the range of 0.002 to $0.078 \mathrm{~g} / \mathrm{m}^{2}$. Unlike the previous two data sets for leaching of the single-phase pyrochlore, the corrected normalized calcium releases for the four single-phase zirconolite samples are all positive. Even so, $\mathrm{Ca}$ in the blank still contributed a sizeable fraction of the total $\mathrm{Ca}$ detected in tests with the ceramics present.

Appendix E contains analytical data obtained from leaching of the zirconolite samples for 3 and 7 days. Blank-corrected normalized mass loss values for $\mathrm{Ca}, \mathrm{Ti}, \mathrm{Ce}, \mathrm{Gd}, \mathrm{Hf}$, and $\mathrm{Mo}$ are also presented.

Normalized releases for molybdenum were calculated using only sample and blank leachate data (and not the acid strip solutions) due to high Mo response from analysis of both the sample and blank acid strip solutions. In the acid strip solutions for samples and blanks, the Mo concentrations ranged from 5-9 ppb (see Table E-1, Molybdenum Data in Appendix E). Average values for normalized releases for $\mathrm{Ti}, \mathrm{Ce}, \mathrm{Gd}$, and $\mathrm{Hf}$ were typically less than $0.01 \mathrm{~g} / \mathrm{m}^{2}$. Normalized losses for Mo were in some cases higher than those of calcium. NL(Mo) values for unirradiated samples ranged from 0.07 to $0.49 \mathrm{~g} / \mathrm{m}^{2}$ and $\mathrm{NL}(\mathrm{Mo})$ values for irradiated samples ranged from 0.05 to $0.65 \mathrm{~g} / \mathrm{m}^{2}$. Data in Appendix A shows that molybdenum is present in the single-phase zirconolite ceramic at much lower levels $\left(0.09 \mathrm{wt} \% \mathrm{MoO}_{3}\right)$ than is calcium $(10.6 \mathrm{wt} \%$ $\mathrm{CaO}$ ). Also, unlike the two data sets for leaching of the single-phase pyrochlore, corrected NL(Mo) values for the four single-phase zirconolite samples are all positive values.

The calcium data shown in Table 8 do not show a significant difference between the leaching behaviors of the irradiated and unirradiated zirconolite pellets. The calcium data in Table 8 suggests that if there is an effect of the heavy ion irradiation on the leachability of the ceramic, the effect is not large enough to increase the normalized mass loss for $\mathrm{Ca}$ above $0.078 \mathrm{~g} / \mathrm{m}^{2}$ in a 7-day test. The magnitude of the effect, if any, cannot be quantified due to the imprecision of the data. The blank-corrected normalized calcium loss in the 3-day tests ranged from 0.045 to $0.067 \mathrm{~g} / \mathrm{m}^{2}$ for the unirradiated samples and 0.002 to $0.031 \mathrm{~g} / \mathrm{m}^{2}$ for the irradiated samples. In the 7-day tests the values ranged from 0.008 to $0.036 \mathrm{~g} / \mathrm{m}^{2}$ for the unirradiated samples and 0.020 to $0.078 \mathrm{~g} / \mathrm{m}^{2}$ or the irradiated samples. Furthermore, there appears to be no discernable differences in the amount of calcium leached for the longer 7-day tests relative to the 3-day tests. An average normalized calcium release value for all 3 -day tests is $0.036 \pm 0.027 \mathrm{~g} / \mathrm{m}^{2}$, whereas the 7-day tests average normalized calcium loss is $0.035 \pm 0.031 \mathrm{~g} / \mathrm{m}^{2}$. 
Table 8. Measured Concentrations and Normalized Mass Loss for Calcium from 3-Day and 7-Day MCC-1 Tests at $90^{\circ} \mathrm{C}$ with Duplicate Samples of Unirradiated and Irradiated Single-Phase Zirconolite Ceramics Polished to 600 Grit

Mass Ca in Leachate (L) and Acid Strip (AS)- micrograms Ca

Concentration $\mathrm{Ca}$ in Leachate and Acid Strip - $\mathrm{mg} / \mathrm{L}$

\begin{tabular}{|c|c|c|c|c|c|c|c|}
\hline \multicolumn{2}{|c|}{ Unirradiated Pellet 1} & \multirow{2}{*}{$\begin{array}{c}\text { Leachate } \\
\text { Concentration } \\
(\mathrm{mg} / \mathrm{L})\end{array}$} & \multirow[b]{2}{*}{$\begin{array}{c}\text { Nonrad } 1 \\
\text { AS }(\mu g)\end{array}$} & \multirow{2}{*}{$\begin{array}{c}\text { Acid Strip } \\
\text { Concentration } \\
(\mathrm{mg} / \mathrm{L})\end{array}$} & \multirow[b]{2}{*}{$\begin{array}{c}\text { Total Mass } \\
(\mu \mathrm{g})\end{array}$} & \multirow{2}{*}{$\begin{array}{l}\text { Uncorrected } \\
\mathrm{NL}(\mathrm{Ca}) \\
\left(\mathrm{g} / \mathrm{m}^{2}\right)\end{array}$} & \multirow{2}{*}{$\begin{array}{c}\text { Corrected } \\
\text { NL(Ca) } \\
\left(\mathrm{g} / \mathrm{m}^{2}\right)\end{array}$} \\
\hline $\begin{array}{l}\text { Time } \\
\text { (days) }\end{array}$ & $\begin{array}{c}\text { Nonrad } 1 \\
L(\mu \mathrm{g})\end{array}$ & & & & & & \\
\hline 3 & 0.8 & 0.041 & 0.8 & 0.045 & $\overline{1.6}$ & 0.065 & 0.045 \\
\hline 7 & 1.0 & 0.053 & 0.2 & 0.009 & 1.2 & 0.050 & 0.008 \\
\hline
\end{tabular}

\begin{tabular}{|c|c|c|c|c|c|c|c|}
\hline \multicolumn{2}{|c|}{ Unirradiated Pellet 2} & \multirow{2}{*}{$\begin{array}{c}\text { Leachate } \\
\text { Concentration } \\
(\mathrm{mg} / \mathrm{L})\end{array}$} & \multirow[b]{2}{*}{$\begin{array}{c}\text { Nonrad } 2 \\
\text { AS }(\mu \mathrm{g})\end{array}$} & \multirow{2}{*}{$\begin{array}{c}\text { Acid Strip } \\
\text { Concentration } \\
(\mathrm{mg} / \mathrm{L})\end{array}$} & \multirow[b]{2}{*}{$\begin{array}{c}\text { Total Mass } \\
(\mu \mathrm{g})\end{array}$} & \multirow{2}{*}{$\begin{array}{l}\text { Uncorrected } \\
\text { NL(Ca) } \\
\left(\mathrm{g} / \mathrm{m}^{2}\right)\end{array}$} & \multirow{2}{*}{$\begin{array}{c}\text { Corrected } \\
\text { NL(Ca) } \\
\left(\mathrm{g} / \mathrm{m}^{2}\right)\end{array}$} \\
\hline $\begin{array}{l}\text { Time } \\
\text { (days) }\end{array}$ & $\begin{array}{c}\text { Nonrad } 2 \\
L(\mu g)\end{array}$ & & & & & & \\
\hline 3 & 1.2 & 0.061 & 0.8 & 0.042 & 2.0 & 0.087 & 0.067 \\
\hline 7 & 0.5 & 0.026 & 1.3 & 0.078 & 1.8 & 0.080 & 0.036 \\
\hline
\end{tabular}

\begin{tabular}{|c|c|c|c|c|c|c|c|}
\hline \multicolumn{2}{|c|}{ Irradiated Pellet 1} & \multirow{2}{*}{$\begin{array}{c}\text { Leachate } \\
\text { Concentration } \\
(m g / L)\end{array}$} & \multirow[b]{2}{*}{$\begin{array}{l}\text { Rad 1 } \\
\text { AS }(\mu g)\end{array}$} & \multirow{2}{*}{$\begin{array}{c}\text { Acid Strip } \\
\text { Concentration } \\
(\mathrm{mg} / \mathrm{L})\end{array}$} & \multirow[b]{2}{*}{$\begin{array}{c}\text { Total Mass } \\
(\mu \mathrm{g})\end{array}$} & \multirow{2}{*}{$\begin{array}{c}\text { Uncorrected } \\
\text { NL(Ca) } \\
\left(\mathrm{g} / \mathrm{m}^{2}\right)\end{array}$} & \multirow{2}{*}{$\begin{array}{c}\text { Corrected } \\
\text { NL(Ca) } \\
\left(\mathrm{g} / \mathrm{m}^{2}\right)\end{array}$} \\
\hline $\begin{array}{c}\text { Time } \\
\text { (days) }\end{array}$ & $\begin{array}{l}\text { Rad } 1 \\
L(\mu g)\end{array}$ & & & & & & \\
\hline 3 & 0.9 & 0.046 & 0.3 & 0.018 & 1.2 & 0.050 & 0.031 \\
\hline 7 & 0.7 & 0.040 & 0.7 & 0.043 & 1.5 & 0.063 & 0.020 \\
\hline
\end{tabular}

\begin{tabular}{|c|c|c|c|c|c|c|c|}
\hline \multicolumn{2}{|c|}{ Irradiated Pellet 2} & \multirow{2}{*}{$\begin{array}{c}\text { Leachate } \\
\text { Concentration } \\
\text { (mg/L) }\end{array}$} & \multirow[b]{2}{*}{$\begin{array}{c}\operatorname{Rad} 2 \\
\text { AS }(\mu g)\end{array}$} & \multirow{2}{*}{$\begin{array}{c}\text { Acid Strip } \\
\text { Concentration } \\
(\mathrm{mg} / \mathrm{L})\end{array}$} & \multirow[b]{2}{*}{$\begin{array}{c}\text { Total Mass } \\
(\mu \mathrm{g})\end{array}$} & \multirow{2}{*}{$\begin{array}{l}\text { Uncorrected } \\
\text { NL(Ca) } \\
\left(\mathrm{g} / \mathrm{m}^{2}\right)\end{array}$} & \multirow{2}{*}{$\begin{array}{c}\text { Corrected } \\
\text { NL(Ca) } \\
\left(\mathrm{g} / \mathrm{m}^{2}\right)\end{array}$} \\
\hline $\begin{array}{c}\text { Time } \\
\text { (days) }\end{array}$ & $\begin{array}{l}\operatorname{Rad} 2 \\
L(\mu g)\end{array}$ & & & & & & \\
\hline 3 & 0.3 & 0.016 & 0.2 & 0.011 & 0.5 & 0.021 & 0.002 \\
\hline 7 & 1.7 & 0.089 & 1.1 & 0.062 & 2.9 & 0.120 & 0.078 \\
\hline
\end{tabular}


Table 8. Continued

\begin{tabular}{c|ccccc|}
$\begin{array}{c}\text { Blanks } \\
\begin{array}{c}\text { Time } \\
\text { (days) }\end{array}\end{array}$ & $L(\mu \mathrm{g})$ & $\begin{array}{c}\text { Leachate } \\
\text { Concentration } \\
(\mathrm{mg} / \mathrm{L})\end{array}$ & AS $(\mu \mathrm{g})$ & $\begin{array}{c}\text { Acid Strip } \\
\text { Concentration } \\
(\mathrm{mg} / \mathrm{L})\end{array}$ & $\begin{array}{c}\text { Total Mass } \\
(\mu \mathrm{g})\end{array}$ \\
\hline 3 & 0.2 & 0.012 & 0.2 & 0.008 & 0.4 \\
3 & 0.1 & 0.005 & 0.4 & 0.019 & 0.4 \\
3 & 0.1 & 0.008 & 0.4 & 0.024 & 0.6 \\
\hline 7 & 0.4 & 0.019 & 0.4 & 0.025 & 0.8 \\
7 & 0.6 & 0.032 & 0.2 & 0.011 & 0.8 \\
7 & 0.6 & 0.028 & 0.5 & 0.029 & 1.1 \\
7 & 0.3 & 0.016 & 1.0 & 0.053 & 1.3
\end{tabular}

Total Calcium Mass *

Data: (micrograms)

\begin{tabular}{|c|c|c|c|c|c|c|c|}
\hline 3 Day: & Average & Std. Dev. & \% RSD & 7 Dav: & Average & Std. Dev. & \% RSD \\
\hline Nonrad & 1.8 & 0.3 & 17 & Nonrad & 1.5 & 0.4 & 29 . \\
\hline Rad & 0.8 & 0.5 & 57 & $\operatorname{Rad}$ & 2.2 & 1.0 & 46 \\
\hline 3 Blanks & & & & 4 Blanks & & & \\
\hline (Leachate) & 0.2 & 0.1 & 38 & (Leachate) & 0.5 & 0.1 & 30 \\
\hline (Acid Strip) & 0.3 & 0.2 & 46 & (Acid Strip) & 0.5 & 0.3 & 60 \\
\hline Total & 0.5 & 0.1 & 24 & Total & 1.0 & 0.2 & 23 \\
\hline
\end{tabular}

* Total mass calcium detectable at minimum detection limit of $\approx 5$ ppb equal to:

$0.018 \mathrm{~L} \times 5 \mu \mathrm{g} / \mathrm{L} \approx 0.1$ micrograms

\begin{tabular}{|cccc|}
\hline pH Data & Replicates & $\begin{array}{c}\text { Final** } \\
\mathrm{pH}\end{array}$ & $\begin{array}{c}\text { Test } \\
\text { Duration } \\
\text { (days) }\end{array}$ \\
Nonrad 1\&2 & 2 & $6.2 \pm 0.2$ & 3 \\
Rad 1\&2 & 2 & $6.0 \pm 0.2$ & 3 \\
Nonrad 1\&2 & 2 & $6.2 \pm 0.6$ & 7 \\
Rad 1\&2 & 2 & $6.2 \pm 0.1$ & 7 \\
\hline
\end{tabular}

** Initial $\mathrm{pH}$ value for 3 -day tests $=5.6$; Final $\mathrm{pH}$ values for 3-day blanks ( 3 samples) $=6.0 \pm 0.3$;

Initial $\mathrm{pH}$ value for 7-day tests $=6.3$; Final $\mathrm{pH}$ values for 7-day blanks ( 4 samples $)=5.4 \pm 0.1$ 


\section{E. Comparison of SRTC Data to ANL MCC-1 Monolith Leach Tests on Crystalline Ceramics}

Researchers at ANL have recently performed MCC-1 leach tests on a variety of titanate ceramics under consideration for Pu disposition. It is therefore useful to compare the MCC-1 leach data described above (SRTC-fabricated baseline, PNNL-fabricated single-phase pyrochlore and single-phase zirconolite) with the ANL results. In one set of experiments, ANL tested a pyrochlore-rich ceramic (240-grit finish ) in an MCC-1 test at $90^{\circ} \mathrm{C}$ for 3-days. The pyrochlore-rich ceramic was prepared by LLNL and contained $21 \% U$ (elemental) and used cerium as surrogate for plutonium [19]. ANL also tested an older formulation, · zirconolite-rich Ba-containing ceramic under the same conditions. This ceramic was also prepared by LLNL and contained $12 \% \mathrm{PuO}_{2}[21]$.

One prominent difference in the MCC-1 tests performed at Argonne and at SRTC is the surface finish. ANL used pellets that were polished to a 240-grit finish, while all SRTC tests used monoliths polished to 600 grit, which is much smoother. Thus, for a given equivalent geometric surface area, the ANL ceramics actually had a larger exposed surface area due to the slightly rougher surface finish. Researchers at ANL and the Australian National Science and Technology Organization (ANSTO) have recently examined the effects of surface finish on dissolution rates of titanate-based ceramics [22,23]. The ANL and ANSTO studies examined MCC-1 leach testing on ceramics with surface finishes ranging from $1 \mu \mathrm{m}$, i.e., a "mirror polish' to 600-grit to 240-grit. Data from these tests indicate that different surface finishes have only a minor effect on dissolution rates.

Table 9 compares data from 3-day MCC-1 testing with SRTC A0 baseline, PNNL pyrochlore and singlephase zirconolite materials (nonrad or rad), and 3-day MCC-1 leach test data from both ANL studies. Similar comparisons are made with 7-day MCC-1 leach data in Table 10. ANL pyrochlore-rich leach studies report only 3-day leach results in Reference 19. Therefore only ANL zirconolite-rich 7-day test data is shown for comparison in Table 10. As expected, the range of normalized mass losses for SRTC tests are lower than ranges reported for the ANL data. This is true for both the unirradiated and irradiated samples in the SRTC tests. This difference could be due to differences in surface finish (600 grit compared to 240 grit) or to an increased durability of the ceramics tested at SRTC. 
Table 9. Normalized Release of Calcium, NL(Ca) in $\mathrm{g} / \mathrm{m}^{2}$, from 3-Day MCC-1 Leach Tests at SRTC and ANL for Various Crystalline Ceramics

\begin{tabular}{|c|c|c|}
\hline 3-Day Test Sets & $\begin{array}{c}\text { Normalized Calcium } \\
\text { Release, } \mathrm{g} / \mathrm{m}^{2}\end{array}$ & \\
\hline SRTC A0 Baseline ${ }^{1}$ & $0.057-0.178$ & SRTC Tests \\
\hline $\begin{array}{c}\text { PNNL Pyrochlore }^{2} \\
\text { (NONRAD) }\end{array}$ & $0.033-<0.095$ & SRTC Tests \\
\hline $\begin{array}{l}\text { PNNL Pyrochlore }^{2} \\
\text { (RAD) }\end{array}$ & $<0.048-<0.073$ & SRTC Tests \\
\hline $\begin{array}{l}\text { PNNL Zirconolite }^{2} \\
\text { (NONRAD) }\end{array}$ & $0.045-0.067$ & SRTC Tests \\
\hline $\begin{array}{l}\text { PNNL Zirconolite }^{2} \\
\text { (RAD) }\end{array}$ & $0.002-0.031$ & SRTC Tests \\
\hline ANL Pyrochlore-rich ${ }^{3}$ & $1.0 \pm 0.6$ & ANL Tests \\
\hline ANL Zirconolite-rich ${ }^{4}$ & $2.1 \pm 0.5$ & ANL Tests \\
\hline
\end{tabular}

(1) Cerium-containing A0 pyrochlore-rich baseline fabricated at SRTC. MCC-1 leach tested at SRTC at $90^{\circ} \mathrm{C}$, 3-day, 600 grit finish; See Table 5 .

(2) Cerium-containing pyrochlore and zirconolite single-phase ceramic fabricated at PNNL. MCC-1 leach tested at SRTC at $90^{\circ} \mathrm{C}, 3$-day, 600 grit finish; See Tables 7 and 8.

(3) Uranium-containing pyrochlore-rich fabricated at LLNL. MCC-1 leach tested at ANL at $90^{\circ} \mathrm{C}, 3$-day, 240 grit finish, see Reference 19.

(4) Plutonium-containing zirconolite-rich fabricated at LLNL. MCC-1 leach tested at ANL at $90^{\circ} \mathrm{C}, 3$-day, 240 grit finish, see Reference 21. 
Table 10. Normalized Release of Calcium, NL(Ca) in $\mathrm{g} / \mathrm{m}^{2}$, from 7-Day MCC-1 Leach Tests at SRTC and ANL for Various Crystalline Ceramics

\begin{tabular}{|c|c|c|}
\hline 7-Day Test Sets & $\begin{array}{c}\text { Normalized Calcium } \\
\text { Release, } \mathbf{g} / \mathbf{m}^{2}\end{array}$ & SRTC Tests \\
\hline SRTC A0 Baseline & $0.194-0.269$ & SRTC Tests \\
\hline $\begin{array}{c}\text { PNNL Pyrochlore } \\
\text { (NONRAD) }\end{array}$ & $0.026-0.038$ & SRTC Tests \\
\hline $\begin{array}{c}\text { PNNL Pyrochlore } \\
\text { (RAD) }\end{array}$ & $0.015-<0.042$ & SRTC Tests \\
\hline $\begin{array}{c}\text { PNNL Zirconolite } \\
\text { (NONRAD) }\end{array}$ & $0.008-0.036$ & SRTC Tests \\
\hline $\begin{array}{c}\text { PNNL Zirconolite } \\
\text { (RAD) }\end{array}$ & $0.020-0.078$ & ANL Tests \\
\hline $\begin{array}{c}\text { ANL Zirconolite-rich } \\
\text { (2) }\end{array}$ & 1.5 & \\
\hline
\end{tabular}

(1) Cerium-containing A0 pyrochlore-rich baseline fabricated at SRTC. MCC-1 leach tested at SRTC at $90^{\circ} \mathrm{C}$, 3-day, 600 grit finish; See Table 5.

(2) Cerium-containing pyrochlore and zirconolite single-phase ceramic fabricated at PNNL. MCC-1 leach tested at SRTC at $90^{\circ} \mathrm{C}, 3$-day, 600 grit finish; See Tables 7 and 8.

(3) Plutonium-containing zirconolite-rich fabricated at LLNL. MCC-1 leach tested at ANL at $90^{\circ} \mathrm{C}, 3$-day, 240 grit finish, see Reference 21. 


\section{CONCLUSIONS}

The purpose of this investigation was to study the effects of heavy-ion irradiation on the durability of titanate-based ceramics designed for the immobilization of plutonium. The results of this investigation support the following conclusions.

1. An effect of ion irradiation on the leaching of the pyrochlore and zirconolite samples could not be detected. If one exists, it is not large enough to increase the measured mass losses above their already low values ( $<0.1 \mathrm{~g} / \mathrm{m}^{2}$ based on Ca mass loss from 1-day tests).

2. Normalized releases from these two single-phase ceramics for all matrix elements were near or below the normalized releases observed for an $\mathrm{A} 0$ baseline pyrochlore-rich ceramic fabricated and leach tested at SRTC, and similar samples leached in recent ANL studies.

3. As a result of the low normalized mass losses, concentrations of leached elements in the blanks were usually comparable to and in some cases greater than in tests where the samples were present. This was true even though the concentrations in the blanks were as low as published values for similar tests.

4. The normalized mass losses measured for both the irradiated and unirradiated samples of singlephase pyrochlore and zirconolite are low compared to results of similar tests on these types of ceramics. This difference could be due to differences in surface finish (600 grit compared to 240 grit) or to an increased durability of the ceramics tested at SRTC. It is possible that these ceramics were made with extra care than other samples (i.e., they were reacted more fully than routine samples) and thus have superior performance characteristics. 


\section{ACKNOWLEDGMENTS}

The authors gratefully acknowledge all assistance provided by SRTC Analytical Development Section (ADS) personnel during this study. D. M. Marsh provided assistance in all laboratory activities. C. R. Biddle acknowledges support by the Oak Ridge Institute of Science and Engineering (ORISE) Postgraduate Research Program. SRTC-fabricated ceramics used in this study were fabricated and provided by J. M. Pareizs. The authors would like to thank all PNNL personnel (D. Strachan, J. Vienna and W. Weber) involved in the fabrication, irradiation and shipment of ceramic test samples. The authors also appreciate helpful comments contributed in the preparation of this report from H. Shaw of LLNL, A. Bakel of ANL and J. Marra of SRTC. 


\section{REFERENCES}

1. "Immobilization Program Peer Review: Fissile Materials Disposition Immobilization Team Summary", ITT-96-051-LWG, 5/2/96 , P-31, Lawrence Livermore National Laboratory, Livermore, CA, April 24-25, 1996.

2. "Integrated Development and Testing Plan for Plutonium Immobilization Project", PIP-98-064, LLNL Document: UCRL-ID-131608, DRAFT, Lawrence Livermore National Lab., Westinghouse Savannah River Co., Argonne National Lab. and Pacific Northwest National Lab., December 18, 1998.

3. "Development of a ceramic Form for Immobilization of Excess Plutonium", R. Van Konynenburg, B. Ebbinghaus, R. Ryerson, H. Shaw and P. Curtis, UCRL-JC-127259, Lawrence Livermore National Laboratory, April 22, 1997.

4. "Technical Evaluation Panel Summary Report: Ceramic and Glass Immobilization Options", B. R. Myers, G. A. Armantrout, C. M. Jantzen, A. Jostens, J. M. McKibben, H. F. Shaw, D. M. Strachan and J. D. Vienna, UCRL-D-129315, Lawrence Livermore National Laboratory, 1998.

5. "Research and Development Task Plan: Plutonium Immobilization Form and Process Development", C. A. Cicero-Herman, PIP-TP-98-001, Lawrence Livermore National Laboratory, March 2, 1998.

6. "Plutonium Immobilization Project Baseline Formulation", B. Ebbinghaus et al., Plutonium Immobilization Project (PIP), UCRL-ID-133089, PIP-99-012, February 1999.

7. "Radiation Effects in Crystalline Ceramics for the Immobilization of High-Level Waste and Plutonium", W. J. Weber et al., Journal of Materials Research, Vol. 13, No. 6, June 1998.

8. "Radiation Effects in Nuclear Waste Forms for High-Level Radioactive Waste", R. C. Ewing, W. J. Weber and F. W. Clinard, Jr., Progress in Nuclear Energy, Vol. 29, No. 2, pp. 63-127, 1995.

9. "Crystalline Titanate Ceramic Nuclear Waste Forms: Leaching and Radiation Damage", R. G. Dosch, C. J. Northrup and T. J. Headley, J. Am. Ceram. Soc., 68[6], pp. 330-337, 1985.

10. "In situ studies of ion irradiated zirconolite, pyrochlore and perovskite", K. L. Smith, N. J. Zaluzec and G. R. Lumpkin, J. Nuc. Materials, Vol. 250, pp. 36-52, 1997.

11. "Effects of Self-Radiation Damage on the Leachability of Actinide-Host Phases", J. W. Wald and W. J. Weber, Advances in Ceramics, Vol. 8, Nuclear Waste Management, Edited by G.G. Wicks and W.A. Ross, American Ceramic Society, pp. 71-75, 1984.

12. "Near-surface leaching studies of Pb-implanted Savannah River Plant waste glass", G. W. Arnold, C. J. M. Northrup and N. E. Bibler, Scientific Basis for Nuclear Waste Management-V, W. Lutze, Editor, pp. 357-368, North-Holland, New York, 1982.

13. "A comparison of the corrosion characteristics of synthetic monazite and borosilicate glass containing simulated nuclear waste glass", B. C. Sales, C. W. White and L. A. Boatner, Nucl. Chem. Waste Mgmt, Vol. 4, pp. 281-289, 1983.

14. Hj. Matzke, J. Nucl. Mater., Vol. 190, 101, 1992.

15. "Rutherford backscattering investigation of radiation damage effects on the leaching of sphene and sphene-based glass-ceramics", D. V. Stevanovic, D. A. Thompson and E. R. Vance, J. Nucl. Mater., Vol. 161, pp. 169-174, 1998.

16. Quality Assurance Requirements and Description for the Civilian Radioactive Waste Management Program, DOE/RW-0333P, U. S. Department of Energy, Office of Civilian Radioactive Waste Management.

17. "Supplemental Quality Assurance Requirements for EOE/RW-0333P (U)", Savannah River Technology Center Manual L1, Procedure 8.21, Current Revision.

18. "Standard Test Method for Static Leaching of Monolithic Waste Forms for Disposal of Radioactive Waste", ASTM C 1220-92, 1995 Annual Book of ASTM Standards, Vol. 12.01, Philadelphia, Pa, 1995, pp. 710-724.

19. "Corrosion Behavior of Pyrochlore-Rich Titanate Ceramics for Plutonium Disposition; Impurity Effects", A. J. Bakel, V. N. Zyryanov, C. J. Mertz, E. C. Buck and D. B. Chamberlain, Argonne National Laboratory, Materials Research Society Proceedings, Scientific Basis for Nuclear Waste Management XXII, Boston, MA, December, 1998.

20. J. D. Ingle, Jr. and S. R. Crouch, Spectrochemical Analysis, Chapter 6, p. 173, , Prentice Hall, Englewood Cliffs, NJ, 1988. 
21. "Corrosion Behavior of a Zirconolite-Rich Ceramic", A. J. Bakel, E. C. Buck, C. J. Mertz, D. B. Chamberlain and S. F. Wolf, ANL/98-34, December 1998.

22. "Corrosion of Titanate Ceramics - Rates and Effects", A. J. Bakel et al., Argonne National Laboratory, presented September 1-2, 1998, Performance Testing and Dissolution Modeling Meeting at LLNL.

23. "Plutonium Immobilization Project Development and Testing Technical Progress Report", PIP-99-063, p. 11, May 1999. 
WESTINGHOUSE SAVANNAH RIVER COMPANY SAVANNAH RIVER TECHNOLOGY CENTER

APPROVALS

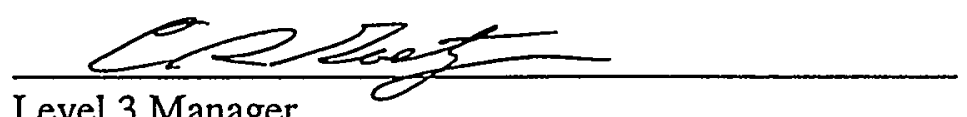

Level 3 Manager,

Immobilization Technology Section

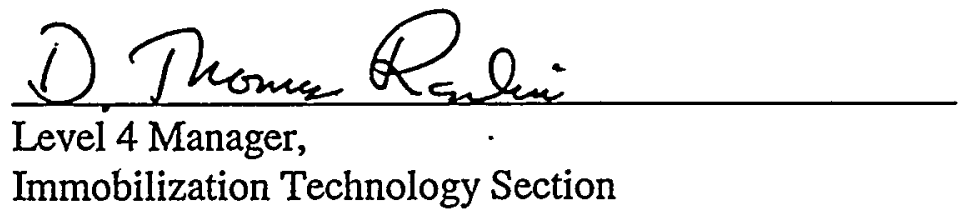

D. Thenar Rankin for James C.Marra Technical Reviewer
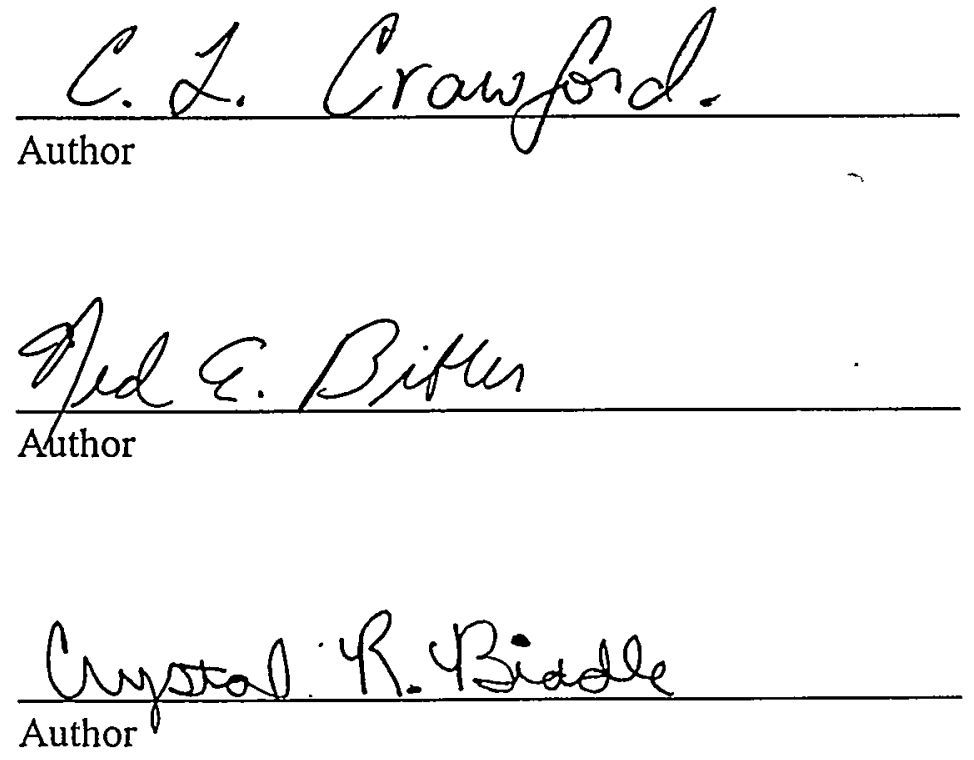

WSRC-TR-99-00263

Rev. 0
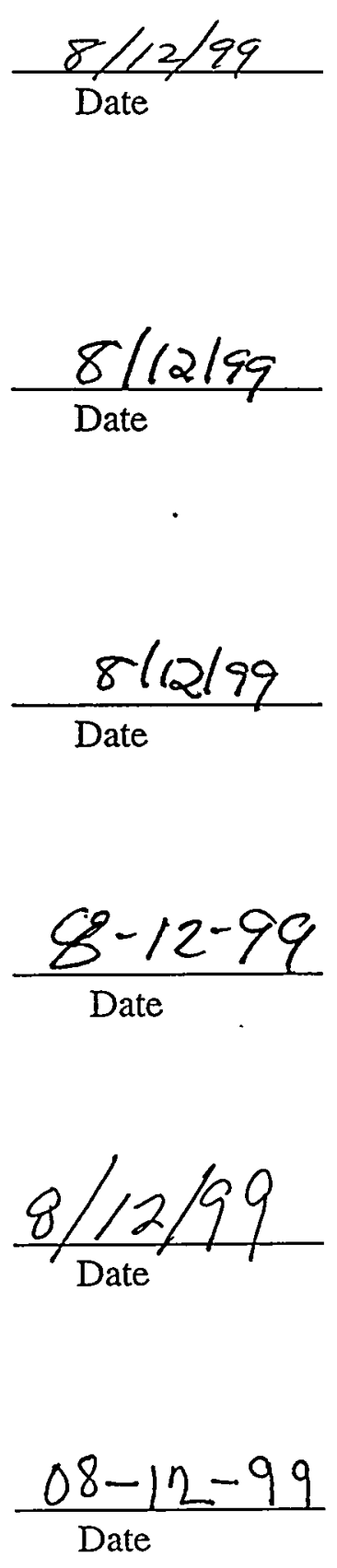

$-33-$ 
APPENDIX A

PACIFIC NORTHWEST NATIONAL LABORATORY REPORT ON ION IRRADIATION OF CERAMIC SAMPLES 


\section{Pacific Northwest National Labơratory \\ Operated by Battelle for the} U.S. Department of Energy

January 22,1999

Dr. Charles Crawiford

Westinghouse Savannah River Company

Aiken, SC 29802

Dear Charles:

\section{DOCUMENTATION OF ION BEAM IRRADIATED SAMPLES}

I sent to you separately four samples consisting of multiple pellets each. These samples are titanate-based ceramic material; some of which have been irradiated to form a metamict zone onthe surface and some of which have not. The purpose of this letter is to document the preparation ơ the materials and their irradiation.

The samples were prepared and characterized according to established technical procedures in our QA Plan with RW0333P pedigree as requested in the Memorandum Purchase:Agreement 30123A (Westinghouse Savannah River Company reference AC02472W). The samples were irradiated in our facilities, but this procedure, while well established, is not part of an established QA Plan with RW0333P pedigree. The conditions under which the samples were inadiated are outlined below.

The samples we sent to you have the following labels:

HZirc5x This is a zirconolite material that was hot pressed at Argonne National Laboratory and sintered again here. The " 5 " means it is the fith formulation we attempted.

HCBIx This is a brannerite material that also was hot pressed at Argonne e National Laboratory and sintered again here. It is a cerium brannerite.

Hbase6 This is a baseline material (pyrochlore rich). It was sintered here. It is also referred to as HB6.

Pyrol7 This is pyrochlore and was sintered here.

902 Battelle Boulevarl - P.O. Box 999 - Riclland, WA 99352

Telephone (509) 3760677 a e-mail denis.strachan@pnl.gov 4 Fax (509) 3763108 
Dr. Charles Crawford

January 22, 1999

Page 2

The preparation and characterization of these materials is discussed in the remaining pages of this letter. If you have questions concerning these materials, please contact me.

Sincerely,

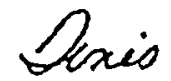

Denis M. Strachan, Program Manager

Plutonium Immobilization Program

cc: N. E. Bibler (WSRC)

S. Budenstein (WSRC)

D. B. Chamberlain (ANL)

B. B. Ebbinghaus (ETXN)

T. Hi Gould (LINL)

M. C. Hash (ANL)

T. Kan (LINL)

H. F. Shaw (LINI) 
Dr. Charles Crawford

January 22, 1999

Page 3

\section{Preparation}

Batching and mixing of the powders in preparation for calcining and sintering were essentially the same for all the materials with the exception that the chemical make up was unique to each. We did not analyze the finished ceramic. Our experience is that if we are careful with the preparation, the final composition is the target composition within experimental error. The powders were batched and wet milled to achieve intimate mixing. About $125 \mathrm{~g}$ of powder was mixed with $150 \mathrm{~mL}$ of demineralized water in a Teflon ${ }^{\circledR}$ jar with screw lid. One kilogram of zirconia grinding media was added anid the jar allowed to roll for 6 to $10 \mathrm{~h}$. After the mixing, the zirconia media was mechanically separated from the sample powder.

The water in the resulting. slurry was partially evaporated by heating and stirring the slurry in a beaker on a hot plate until thick. This thick slurry was eventually transferred to a $110^{\circ} \mathrm{C}$ oven where it remained until dry. The resulting powder was mixed and pressed into $17 \mathrm{~mm}$-diameter pellets under $140 \mathrm{MPa}(20000 \mathrm{psi})$. These pellets were forced through a 20 -mesh screen thereby creating a coarse powder. This powder was then calcined at $750^{\circ} \mathrm{C}$ for $1 \mathrm{~h}$.

Initially, we:found that we did not, get good denisities from pellets formed from these powiders. We sent some of the calcined powders to Dr. Mark Hash at Argonne National Laboratory (see Attachment 1). He transferred the powders to stainless steel cans that were subsequently evacuated and sealed. These can were placed in a hot isostatic press where they were sintered at. $1250^{\circ} \mathrm{C}$ and $170 \mathrm{MPa}(25000 \mathrm{psi})$. When these cans were opened at $\mathrm{PNNL}$, the samples were observed to be chocolate brown and some had low density. In the cases of the zirconolite and brannerite, we core drilled the ceramic from the cans, cut wafers from the hot pressed samples, and sintered the resulting wafers. The zirconolite wafers were sintered at $1400^{\circ} \mathrm{C}$ for $10 \mathrm{~h}$ and the brannerite wafers were sintered under pure flowing $\mathrm{O}_{2}$ at $1330^{\circ} \mathrm{C}$ for $72 \mathrm{~h}$.

The sample of baseline material had good density and the phase assemblage appeared to be correct. We, therefore, cut wafers directly from the hot pressed specimen with a diamondimpregnated saw.

The can for the pyrochlore material failed during the hot isostatic pressing operation. We elected not to try to hot press a new sample. For this material, we made anew batch of powder and pressed several $17 \mathrm{~mm}$-diameter pellets at $140 \mathrm{MPa}$ (20-000 psi). As before, we forced these pellets through a 20-mesh screen to form a coarse powder that was calcined as described above. New $12 \mathrm{~mm}$-diameter pellets were pressed at $70 \mathrm{MPa}(10000 \mathrm{psi})$ and sintered at $1350^{\circ} \mathrm{C}$ for 10 h. These pellets were made so that the final height was $2-3 \mathrm{~mm}$.

All of the wafers and pellets (pyrochlore) were then polished with 600 grit SiC paper under water.

The target compositions are shown in Table 1 . We did not analyze these samples. 
Dr. Charles Crawford

Januaty 22, 1999

Page 4

Table 1. Composition of ceramics in mass\%.

\begin{tabular}{|l|c|c|c|c|}
\hline \multicolumn{1}{|c|}{ Component } & HZirc5x & HCB1x & HBase6 & Pyro17 \\
\hline $\mathrm{Al}_{2} \mathrm{O}_{3}$ & 1.8 & - & - & - \\
\hline $\mathrm{CaO}$ & 10.6 & - & 11.5 & 8.2 \\
\hline $\mathrm{CeO}_{2}$ & 6.1 & 51.8 & 26.8 & 35.4 \\
\hline $\mathrm{Gd}_{2} \mathrm{O}_{3}$ & 2.1 & - & 9.2 & 13.3 \\
\hline $\mathrm{HfO}_{2}$ & 44.6 & - & 11.1 & 3.1 \\
\hline $\mathrm{MoO}_{3}$ & 0.09 & 0.1 & 0.09 & 0.1 \\
\hline $\mathrm{TiO}_{2}$ & 34.8 & 48.1 & 41.2 & 39.9 \\
\hline
\end{tabular}

\section{Density}

We measured the densities of the pellets and wafers with two different methods. We modified the ASTM C373-88 procedure by replacing the 5-hour boiling water treatrient with a.vacuum treatment. We placed the sample to be tested in an Erlenmeyer flask witha side arm and evacuated the flask for $30 \mathrm{~min}$. Before returning the flask to atmospheric pressure, we covered ${ }^{-}$ the sample with water. The rest of the procedure is as written? From this procedure; we get two densities - the "true" density and the bulk density: The "true" density should exclude the open porosity. We also measured the densities in our Micromeretics Helium Gas Pycnometer. Our measured densities are shown in Table 2.

Table 2. Densities $\left(10^{3} \mathrm{~kg} / \mathrm{m}^{3}\right)$ of ceramic samples (wafers and pellets).

\begin{tabular}{|l|l|l|l|l|}
\hline \multicolumn{1}{|c|}{ Sample } & \multicolumn{1}{c|}{ True } & \multicolumn{1}{c|}{ Bülk } & \multicolumn{1}{c|}{ Porosity $(\%)$} & \multicolumn{1}{c|}{ Gas } \\
\hline HZirc5x & $5.514(7)^{\mathrm{a}}$ & $5.507(7)$ & $0.16(53)$ & $5.436(4)$ \\
\hline HCB1x & $4.683(18)$ & $4.207(15)$ & $10.2(3)$ & $4.842(11)$ \\
\hline HBase6 & $5.135(32)$ & $5.002(12)$ & $2.57(81)$ & $5.122(2)$ \\
\hline Pyro17 & $5.081(28)$ & $5.072(23)$ & $0.023(244)$ & $5.099(64)$ \\
\hline
\end{tabular}

a) The number in 0 is the standard deviation ( $1 \sigma)$ in the last place.

With the exception of the brannerite, the densities are quite reasonable. We had many problems with the preparation of the Ce-brannerite not the least of which was trying to obtain a high density while maintaining phase purity.

\section{Sample Condition}

The samples were polished with 600-grit wet/dry silicon carbide paper by hand on a rotating disk with water as a lubricant. The samples were wiped dry with a laboratory paper towel (ChemWipe or similar towel). No other cleaning was used before density measurements and irradiation. Cleaning of the samples must be done prior to performing the MCC-1 tests.

During irradiation, one sample pellet of brannerite broke into several pieces. A backup pellet was irradiated in December and shipped to SRTC. 
Dr. Charles Ctawford

January 22, 1999

Page 5

\section{X-Ray Diffraction Results}

Also attachedarethe diffraction patterns from a sacrificed wafer/pellet from the same batch of samples that were sent to SRTC. These show that the samples are either pure phase or mixtures of the appropriate phases in the case of the baseline material. Two sets of patterns are included (Attachments 2-9) - one in color with the "stick" pattern generated from the Powder Diffraction File and one with just the pattern for the ceramic.

Teclınical Procedures Used in Sample Preparation

\begin{tabular}{|c|c|}
\hline Number & Technical Procedure Title \\
\hline APEL-PIP-1 & $\begin{array}{l}\text { Evacuated Impregnation Method for Apparent Specific Gravity, } \\
\text { Bulk Density, and-Apparețit Porosity Determinations of } \\
\text { Consolidated Solids. }\end{array}$ \\
\hline APEL-PIP-2 & Geometric Density of Fired Ceramic Pellets \\
\hline APELIPIP-3 & $\begin{array}{l}\text { Archimedes (Buoyancy) Method for Apparent Specific Gravity } \\
\text { Determinations of Consolidated Solids. }\end{array}$ \\
\hline APEL-PIP-4 & $\begin{array}{l}\text { Gas Pycnometer Method for Apparent Specific Gravity } \\
\text { Determinations of Consolidated Solids. }\end{array}$ \\
\hline RPI-PIP-1 & $\begin{array}{l}\text { Preparation, Processing, and Testing of Radioactive Glass and } \\
\text { Ceramics: }\end{array}$ \\
\hline RPI-PIP-2 & Fabrication of Ceramic Samples: \\
\hline
\end{tabular}

1) Applies to nonradioactive samples.

\section{Irradiạtions}

The samples were irradiated as the polished wafers/pellets. They were irradiated at the PNNL facility in the Environmental Molecular Sciences Laboratory by Dr. William Weber and his staff. Irradiations were carried out with $0.32 \mathrm{pJ}(2 \mathrm{MeV}) \mathrm{Au}^{2+}$ at normal incidence. The flux was 100 to $400 \mathrm{nA}$ over an irradiation area of $315 \mathrm{~mm}^{2}\left(3.15 \mathrm{~cm}^{2}\right)$ - an area that encompasses the entire specimen surface exposed to the beam. Both surfaces of the sample were irradiated; the edges of the samples were not irradiated. The ion fluence was $540 \mu \mathrm{C}$ (about $5.5 \mathrm{Au}^{2+} / \mathrm{nm}^{2}$ ). No attempt was made to control the temperature, but the temperature was estimated to be $50^{\circ} \mathrm{C}$. In tests run with $\mathrm{MgO}$, the temperature was observed to be $35^{\circ} \mathrm{C}$ for a beam current of $100 \mathrm{nA}$. 
Dr. Charles Crawford

Januaty 22, 1999

Page 6

\author{
Attachment 1 \\ Hot Isostatic Pressing of Select PNNL Powders \\ 11/10/1998 - M.C. Hash. (ANL-E)
}

Four calcined powders were received from PNNL (J. Vienna) on August 18, 1998:

Cerium Branneritel,

Zirconalite5,

Baseline6,

Pyrochlore15.

The powders were loaded into Type 304 stainless steel canisters; - initial dimensions of 3" in height and $I^{\prime \prime}$ in diameter. Powder loading and subsequent canister preparation were all done using standard processing techniques developed in-house for the production of sodalite-glass composites.

Charge Data:

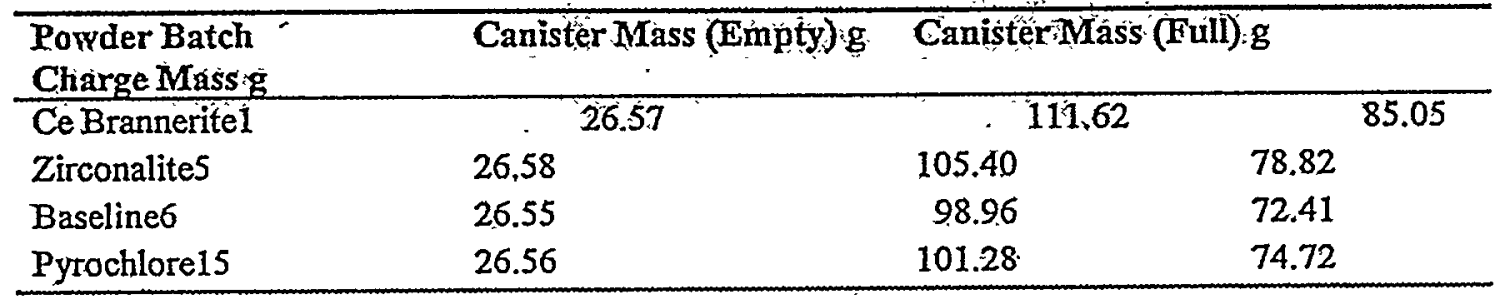

Hot.Isostatic Pressing (HIP):

All four canisters were HII'd on August 24, 1998 to a maximum temperature of $1250^{\circ} \mathrm{C}$ for a soak duration of 10 hours (heating and cooling at $5^{\circ} \mathrm{C} / \mathrm{min}$ ) under an isostatic pressure of 25,000 psi. 


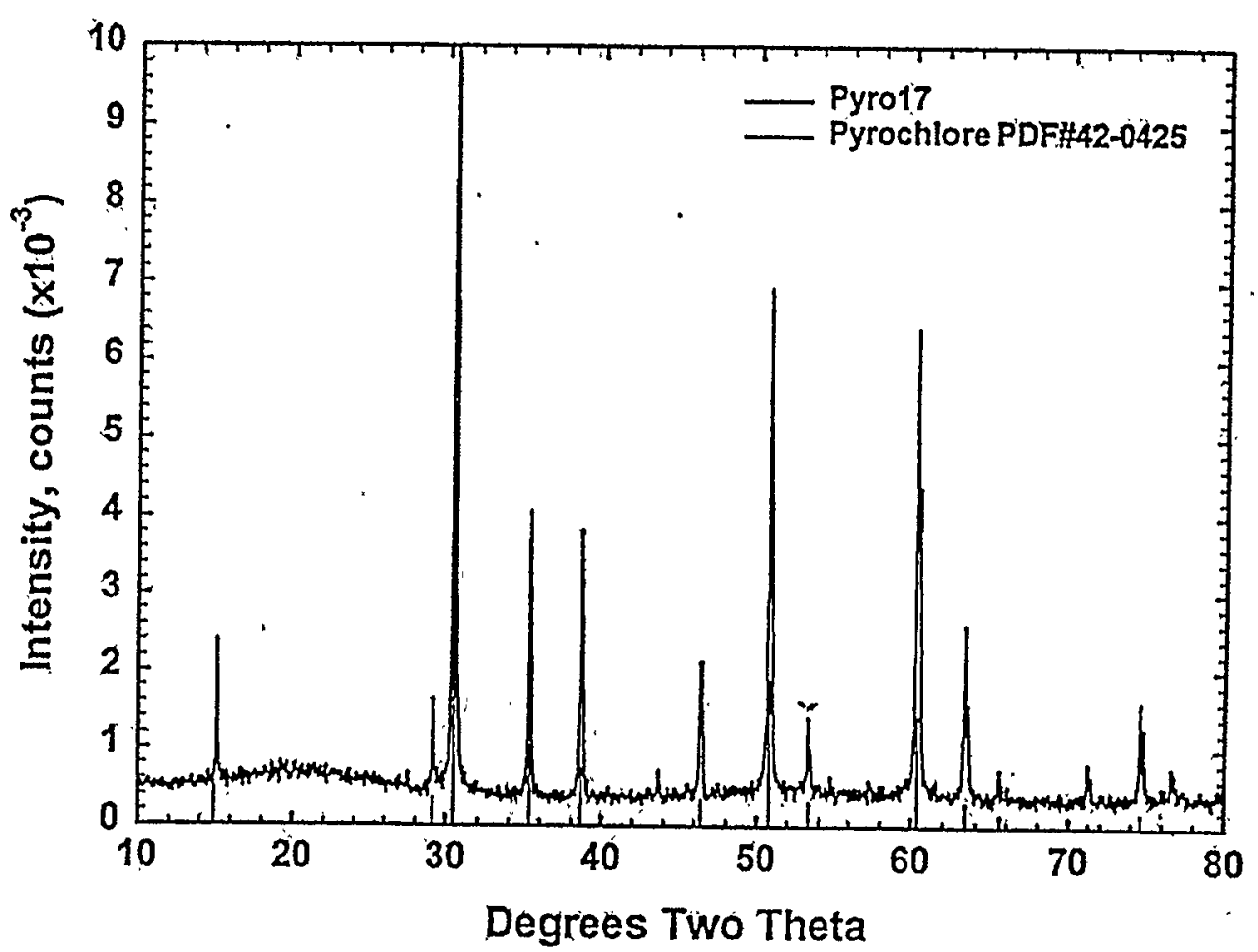


Attachment 3

\section{XRD Results for Sample HZ5X}

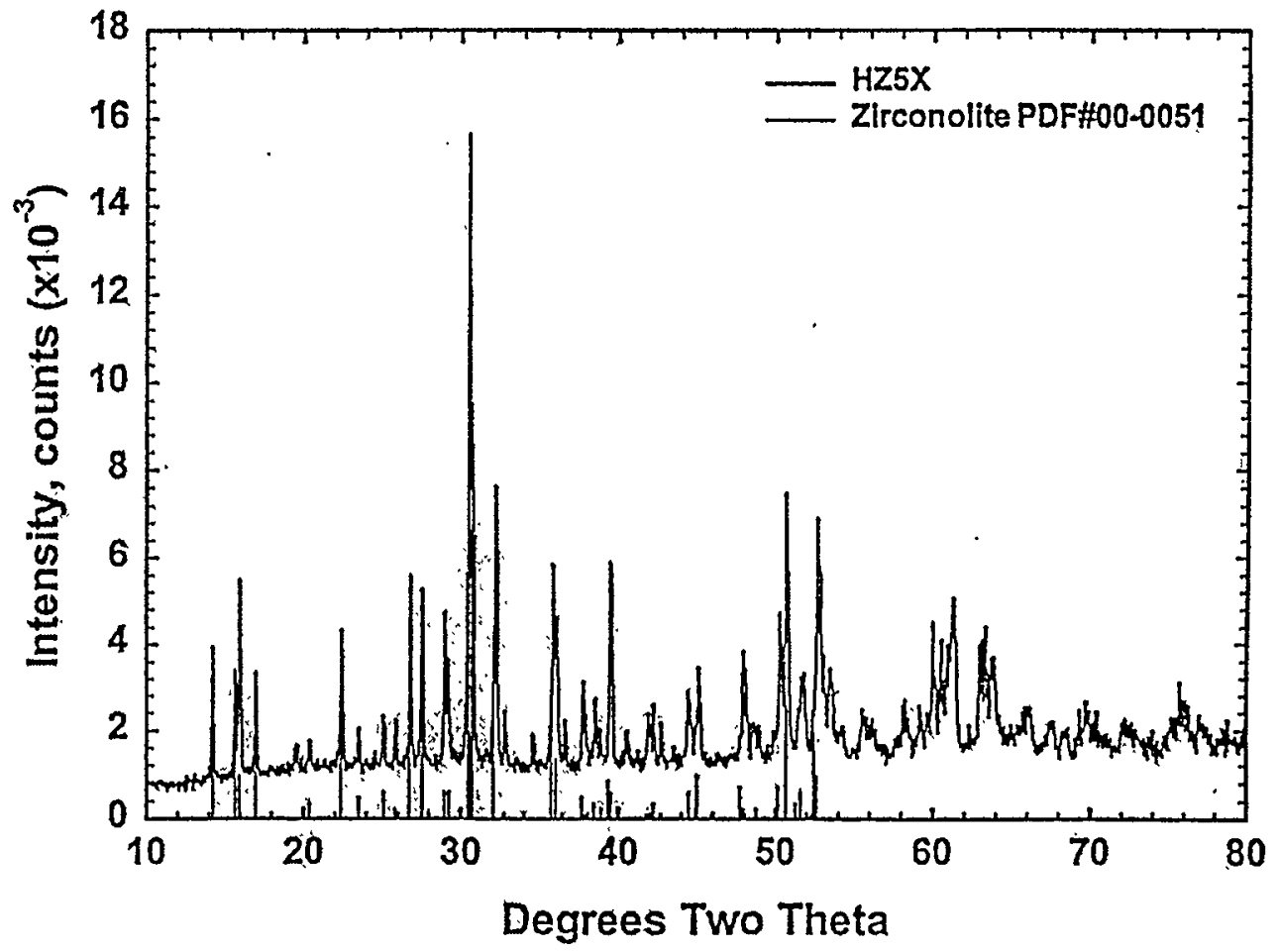

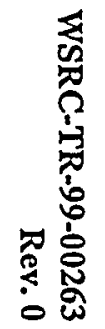




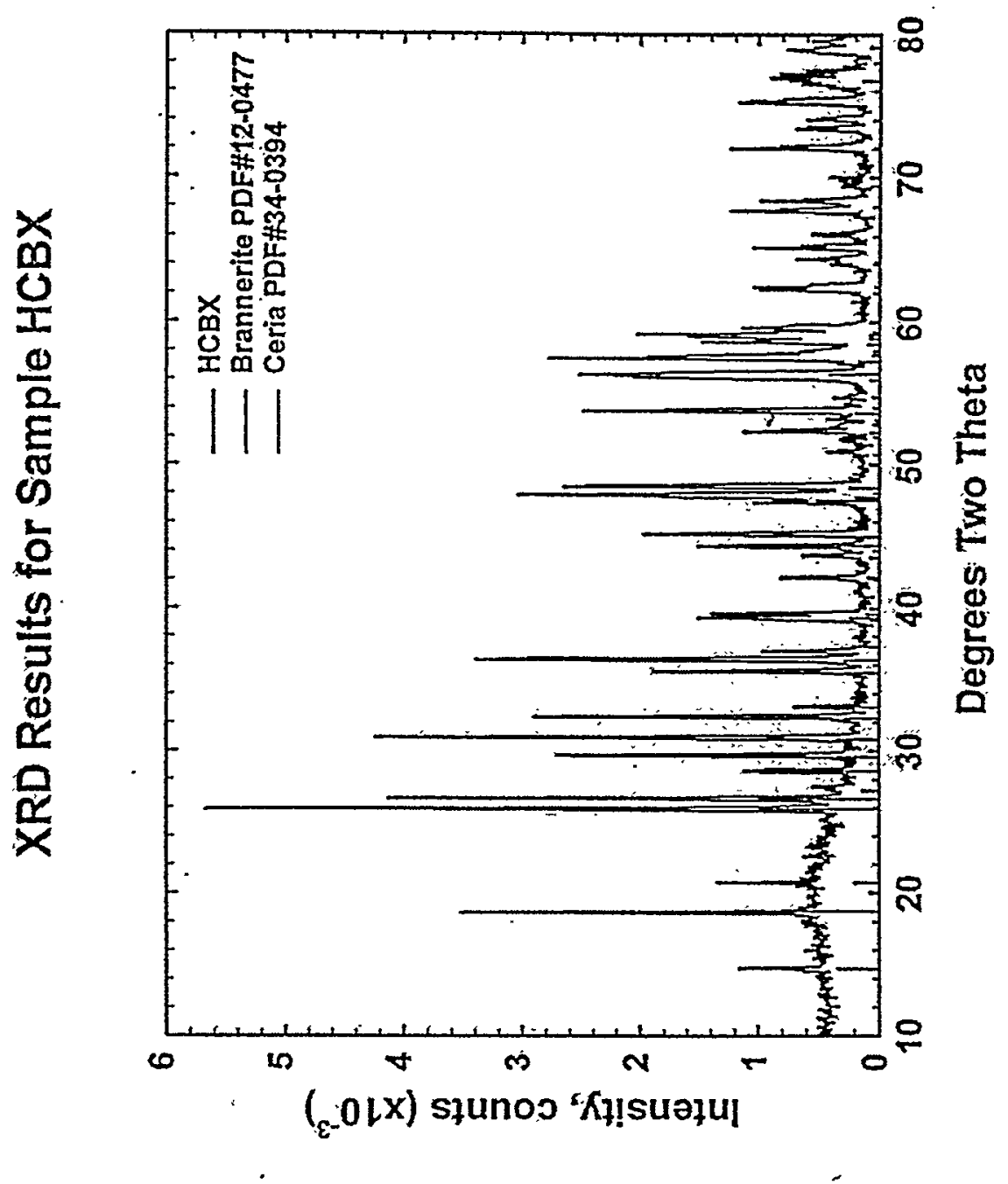


Attachment 5

XRD Results from Sample HB6

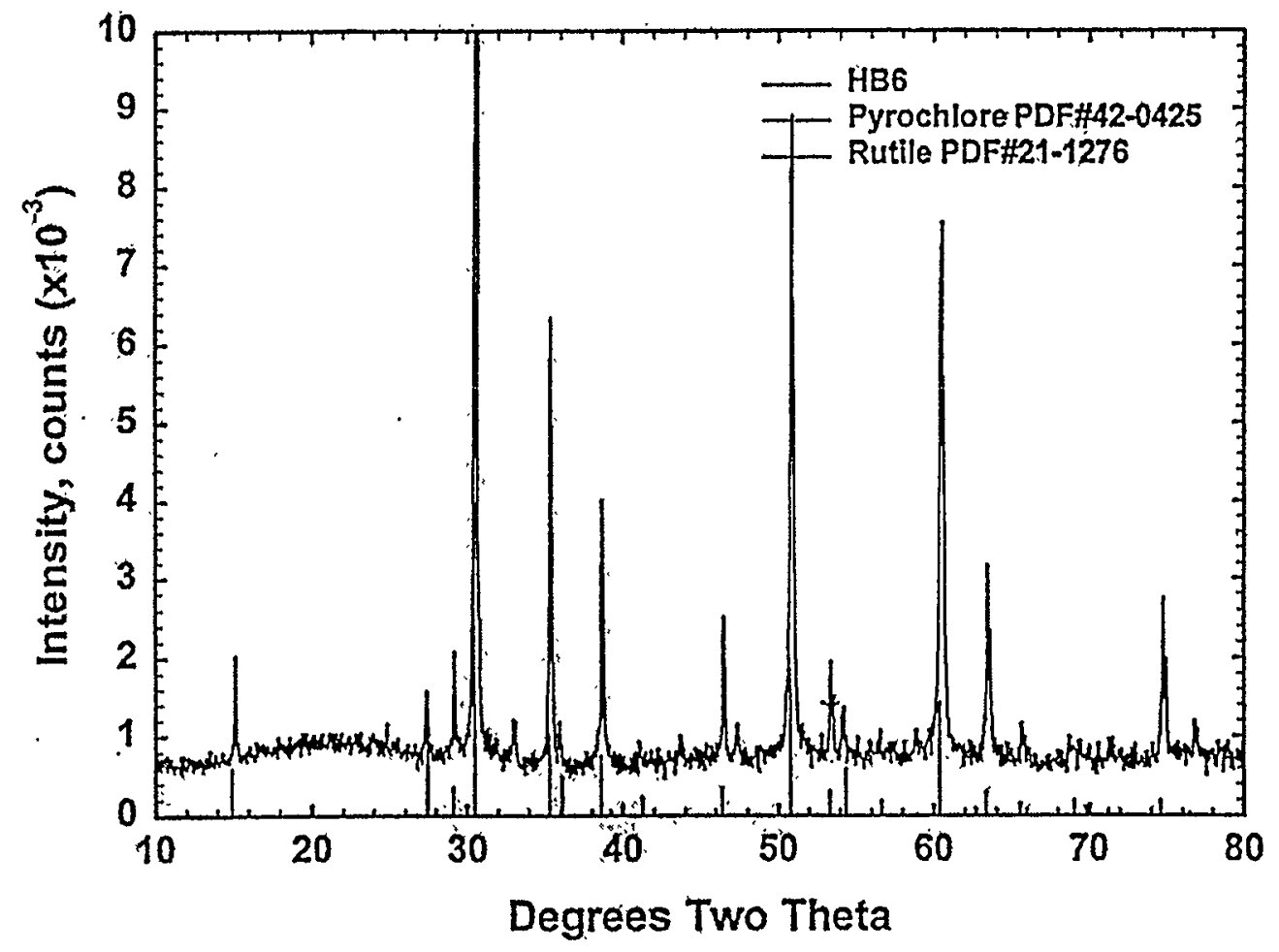

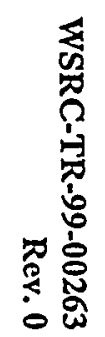




\section{APPENDIX B}

\section{SAVANNAH RIVER TECHNOLOGY CENTER BASELINE CERAMIC FORMULATION}

Baseline ceramic samples were fabricated at SRTC by the general procedure outlined in Table B1. The ceramics were prepared by wet milling reagent chemicals overnight using $1 / 4^{\prime \prime}$ zirconia grinding media. The resulting mixtures were dried at 90 to $100^{\circ} \mathrm{C}$ overnight. Dried samples were size reduced to $<50$ mesh using an agate mortar and pestle. The resulting mixture was calcined in air at $750^{\circ} \mathrm{C}$ for one hour. No granulation was performed. About 1.7 gram of powder was used for each pellet into a $13 \mathrm{~mm}$ die. Each sample was then pressed at $2,000 \mathrm{lbs}(10,000 \mathrm{psi})$ in a $13 \mathrm{~mm}$ diameter die. Sintering of the pressed pellets used nominal sintering schedule of $5^{\circ} \mathrm{C} / \mathrm{min}$ up to $1350^{\circ} \mathrm{C}$, hold for 4 hours in air, followed by a cooling also at $5^{\circ} \mathrm{C} / \mathrm{min}$. Resulting pellets were then sawed into two equal smaller, i.e., thinner pellets, using a diamond saw blade (diamond in copper matrix). These final pellets were then polished under water to 600 grit using $\mathrm{SiC}$ paper.

The target formulation composition is shown in Table B2. This baseline formulation is referred to as the A0 baseline formulation. Cerium was used as surrogate in place of both uranium and plutonium for the SRTC-fabricated A0 baseline ceramics that were leach tested in this study. Densities of resulting ceramic pellets were determined using procedure SRTC procedure GTPU-3-007. Results of density measurements on three representative ceramics are shown in Table B3. A representative sample was also ground and analyzed to obtain the X-ray diffraction pattern (XRD). The resulting pattern is presented in Figure $\mathrm{B} 1$. The XRD pattern shown in Figure $\mathrm{B} 1$ for $\mathrm{A} 0$ baseline ceramic indicates pyrochlore $\left(\mathrm{XTi}_{2} \mathrm{O}_{7}\right)$ as the major phase (2-Theta ${ }^{\circ}$ of $15,31,35,39,47,51,61$ and 63). Minor phases of both rutile $\left(\mathrm{TiO}_{2}\right)\left(2\right.$-Theta ${ }^{\circ}$ of 27 , 36 and 55) and perovskite $\left(\mathrm{CaTiO}_{3}\right)$ (2-Theta ${ }^{\circ}$ of 33 and 47 ) are also identified.

Table B-1. A0 Baseline Ceramic Formulation Procedure Used at SRTC to Prepare Cerium-containing Ceramic Leach Tested at SRTC

\begin{tabular}{|l|l|}
\hline Step & Details \\
\hline 1 & Batch mix oxide/hydroxide precursors \\
\hline 2 & $\begin{array}{l}\text { Wet mill mixture of precursors using } 1 / 4^{\prime \prime} \text { zirconia grinding media } \\
\text { overnight }\end{array}$ \\
\hline 3 & Dry wet milled mixture at $90-100^{\circ} \mathrm{C}$ \\
\hline 4 & Size reduce dried mixture to $<50$ mesh using agate mortar/pestle \\
\hline 5 & Calcine mixture at $750^{\circ} \mathrm{C}$ for one hour in air \\
\hline 6 & Add 1.7 gram calcined powder to $13 \mathrm{~mm}$ stainless steel die \\
\hline 7 & Press at $2,000 \mathrm{lbs}(10,000$ psi) \\
\hline 8 & $\begin{array}{l}\text { Sinter in air at } 5^{\circ} \mathrm{C} / \mathrm{min} \text { up to } 1350^{\circ} \mathrm{C}, \text { dwell at } 1350^{\circ} \mathrm{C} \text { for } 4 \text { hours, } \\
\text { cool at } 5^{\circ} \mathrm{C} / \mathrm{min}\end{array}$ \\
\hline
\end{tabular}


Table B-2. Composition of Ceramic in Mass\%

\begin{tabular}{|l|l|}
\hline $\begin{array}{l}\text { Base Feed } \\
\text { Materials }\end{array}$ & $\begin{array}{l}\text { A-0 Baseline } \\
(\mathrm{wt} \%)\end{array}$ \\
\hline $\mathrm{CaO}$ & 9.95 \\
\hline $\mathrm{TiO}_{2}$ & 35.87 \\
\hline $\mathrm{HfO}_{2}$ & 10.65 \\
\hline $\mathrm{Gd}_{2} \mathrm{O}_{3}$ & 7.95 \\
\hline $\mathrm{UO}_{2}{ }^{*}$ & 23.69 \\
\hline $\mathrm{PuO}_{2}{ }^{*}$ & 11.89 \\
\hline Total & 100.00 \\
\hline
\end{tabular}

* Both $\mathrm{UO}_{2}$ and $\mathrm{PuO}_{2}$ substituted with $\mathrm{CeO}_{2}$ on a molar basis.

Table B-3. Densities $\left(\mathrm{g} / \mathrm{cm}^{3}\right)$ of SRTC A0 Baseline Ceramic Pellets

\begin{tabular}{|c|c|c|c|c|c|c|c|}
\hline Sample & $\begin{array}{l}\text { Dry Wt. } \\
\text { (g) } \\
\text { D }\end{array}$ & $\begin{array}{l}\text { Suspended } \\
\text { Wt. (g) } \\
\text { S }\end{array}$ & $\begin{array}{l}\text { Saturated } \\
\text { Wt. (g) } \\
\text { M }\end{array}$ & $\begin{array}{l}\text { Volume } \\
\left(\mathrm{cm}^{3}\right) \\
V\end{array}$ & $\begin{array}{l}\text { Apparent } \\
\text { Porosity, } \\
(\%) \\
\mathrm{P}\end{array}$ & $\begin{array}{l}\text { Apparent } \\
\text { Density, } \\
\left(\mathrm{g} / \mathrm{cm}^{3}\right) \\
\mathrm{T}\end{array}$ & $\begin{array}{l}\text { Bulk } \\
\text { Density } \\
\left(\mathrm{g} / \mathrm{cm}^{3}\right) \\
\mathrm{B} \\
\end{array}$ \\
\hline 1 & 1.695 & 1.349 & 1.700 & 0.351 & 1.425 & 4.899 & 4.829 \\
\hline 2 & 1.608 & 1.305 & 1.612 & 0.307 & 1.303 & 5.307 & 5.238 \\
\hline 3 & 1.612 & 1.288 & 1.615 & 0.327 & 0.917 & 4.975 & 4.930 \\
\hline Average & 1.638 & 1.314 & 1.642 & 0.328 & 1.215 & 5.060 & 4.999 \\
\hline St. Dev & 0.049 & 0.031 & 0.050 & 0.022 & 0.265 & 0.217 & 0.213 \\
\hline$\%$ RSD & 3 & 2 & 3 & 7 & 22 & 4 & 4 \\
\hline
\end{tabular}

Equations used in density calculations:

Volume, $\mathrm{V}=\mathrm{M}-\mathrm{S}$

Apparent Porosity, $\mathrm{P}=(\mathrm{M}-\mathrm{D}) / \mathrm{V} * 100$

Apparent Density, $T=D /(D-S)$

Bulk Density, $B=D / V$ 


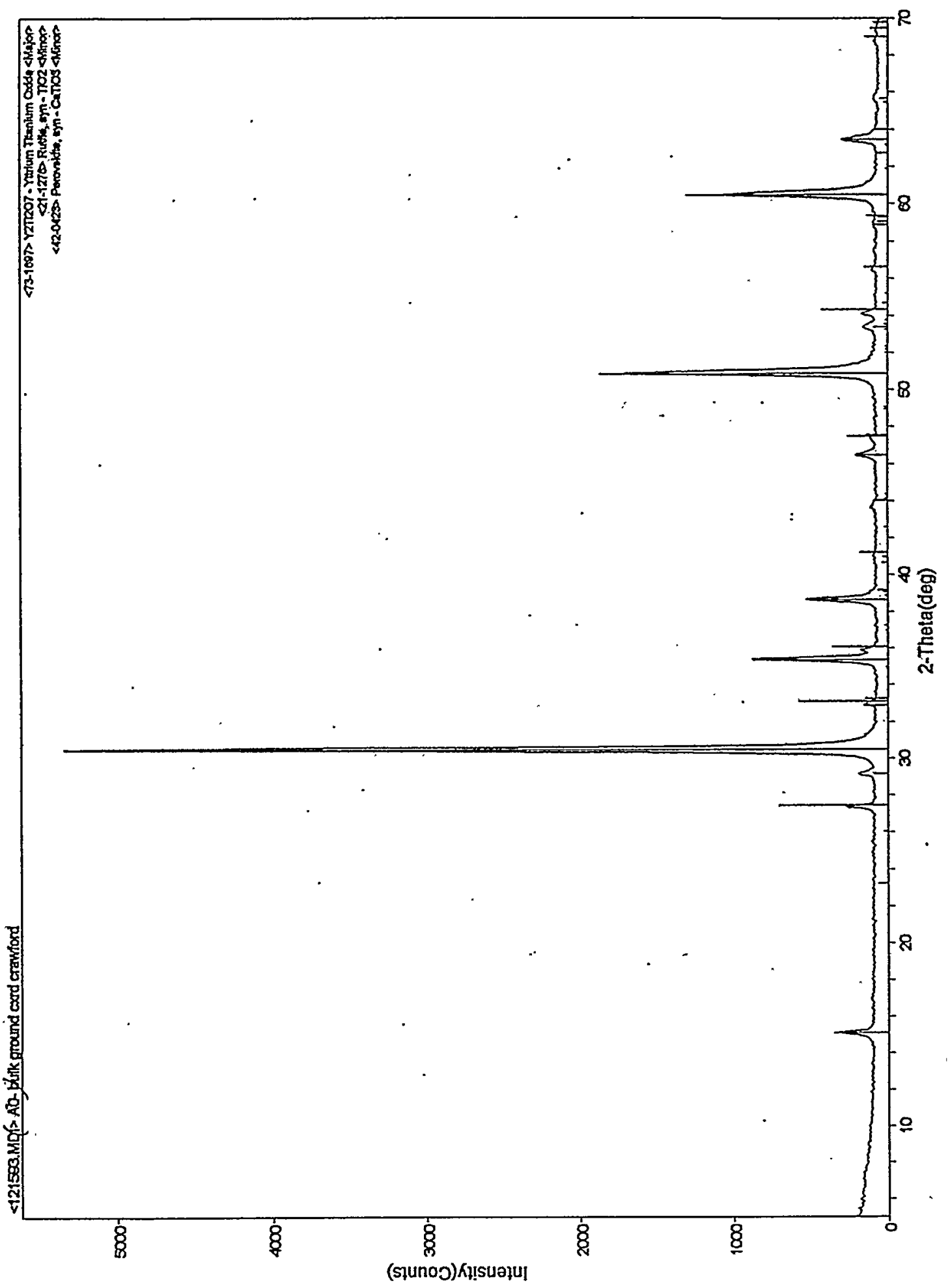

Figure B-1. XRD Pattern of Ground Pellet, SRTC Fabricated A0 Baseline 


\section{APPENDIX C}

\section{ANALYTICAL DATA FOR CALCIUM ANALYSES FROM SRTC AO BASELINE CERAMIC LEACH TESTS}

Table C-1. A0 Baseline Calcium Mass Data from Successive 1-Day Leach Tests

Mass $\mathrm{Ca}$ in Leachate (L) and Acid Strip (AS)- micrograms $\mathrm{Ca}$

Concentration $\mathrm{Ca}$ in Leachate and Acid Strip - mg/L

\begin{tabular}{lc|ccccc}
$\begin{array}{l}\text { SRTC } \\
\text { A0 Baseline }\end{array}$ & $\begin{array}{c}\text { Time } \\
\text { (days) }\end{array}$ & $\begin{array}{c}\text { Sample 1 }(\mu \mathrm{g}) \\
\begin{array}{c}\text { Leachate } \\
\text { Concentration } \\
(\mathrm{mg} / \mathrm{L})\end{array}\end{array}$ & $\begin{array}{c}\text { AS }(\mu \mathrm{g}) \\
\begin{array}{c}\text { Acid Strip } \\
(\mathrm{mg} / \mathrm{L})\end{array}\end{array}$ & $\begin{array}{c}\text { Total Mass } \\
(\mu \mathrm{g})\end{array}$ \\
\hline $1^{\text {st }}$ & 1 & 1.5 & 0.082 & 0.7 & 0.039 & 2.2 \\
$2^{\text {nd }}$ & 1 & 1.1 & 0.059 & 0.7 & 0.041 & 1.8 \\
$3^{\text {rd }}$ & 1 & 1.2 & 0.059 & 0.8 & 0.046 & 2.0 \\
$4^{\text {th }}$ & 1 & 0.8 & 0.041 & 0.6 & 0.034 & 1.4
\end{tabular}

\begin{tabular}{|c|c|c|c|c|c|c|}
\hline & $\begin{array}{c}\text { Time } \\
\text { (days) }\end{array}$ & $\begin{array}{c}\text { Sample } 2 \\
L(\mu \mathrm{g})\end{array}$ & $\begin{array}{c}\text { Leachate } \\
\text { Concentration } \\
\text { (mg/L) }\end{array}$ & $A S(\mu \mathrm{g})$ & $\begin{array}{c}\text { Acid Strip } \\
\text { Concentration } \\
(\mathrm{mg} / \mathrm{L})\end{array}$ & $\begin{array}{c}\text { Total Mass } \\
(\mu \mathrm{g})\end{array}$ \\
\hline $1^{\text {st }}$ & 1 & 2.1 & 0.109 & 0.6 & 0.035 & 2.7 \\
\hline $2^{\text {nd }}$ & 1 & 1.4 & 0.073 & 0.5 & 0.030 & 1.9 \\
\hline $3^{\text {rd }}$ & 1 & 1.1 & 0.059 & 0.6 & 0.036 & 1.7 \\
\hline $4^{\text {th }}$ & 1 & 1.0 & 0.051 & 0.9 & 0.050 & 1.9 \\
\hline
\end{tabular}

\begin{tabular}{ccccccc} 
& \multicolumn{1}{c}{$\begin{array}{c}\text { Time } \\
(\text { days })\end{array}$} & $\begin{array}{c}\text { Blanks } \\
\mathrm{L}(\mu \mathrm{g})\end{array}$ & $\begin{array}{c}\text { Leachate } \\
\text { Concentration } \\
(\mathrm{mg} / \mathrm{L})\end{array}$ & $\mathrm{AS}(\mu \mathrm{g})$ & $\begin{array}{c}\text { Acid Strip } \\
\text { Concentration } \\
(\mathrm{mg} / \mathrm{L})\end{array}$ & $\begin{array}{c}\text { Total Mass } \\
(\mu \mathrm{g})\end{array}$ \\
\hline $1^{\text {st }}$ & 1 & 0.6 & 0.029 & 0.8 & 0.049 & 1.3 \\
$2^{\text {nd }}$ & 1 & 0.6 & 0.030 & 0.5 & 0.029 & 1.1 \\
$3^{\text {rd }}$ & 1 & 0.5 & 0.024 & 0.4 & 0.023 & 0.9
\end{tabular}

\begin{tabular}{|lcccc|}
\hline $\begin{array}{l}\text { * Total Mass Data: } \\
\text { (micrograms) }\end{array}$ & & Average & Std. Dev. & \% RSD \\
& S-1 & 1.9 & 0.4 & 19 \\
& S-2 & 2.0 & 0.4 & 22 \\
& 3 Blanks & 1.1 & 0.2 & 19 \\
\hline
\end{tabular}

\footnotetext{
* Total mass calcium detectable at minimum detection limit of $\approx 5 \mathrm{ppb}$ equal to:

$0.018 \mathrm{~L} \times 5 \mu \mathrm{g} / \mathrm{L} \approx 0.1$ micrograms
} 
Table C-2. Analytical Data from Leach Tests with SRTC A0 Baseline Ceramics

\begin{tabular}{|c|c|c|c|c|c|c|c|}
\hline $\begin{array}{c}\text { Calcium Dat } \\
\text { Sample }\end{array}$ & $\begin{array}{l}\text { Test } \\
\text { Duration } \\
\text { (days) }\end{array}$ & $\begin{array}{l}\text { Leachate } \\
\text { Calcium } \\
(\mathrm{mg} / \mathrm{L})\end{array}$ & $\begin{array}{l}\text { Corrected } \\
\text { Calcium } \\
\text { (mg/L) }\end{array}$ & $\begin{array}{l}\text { Acid Strip } \\
\text { Calcium } \\
\text { (mg/L) }\end{array}$ & $\begin{array}{l}\text { Corrected } \\
\text { Calcium } \\
(\mathrm{mg} / \mathrm{L})\end{array}$ & $\begin{array}{c}\text { Total } \\
\text { Mass Calcium } \\
\text { (g) }\end{array}$ & $\begin{array}{l}\text { Normalized } \\
\text { Mass Loss } \\
\quad\left(\mathrm{g} / \mathrm{m}^{2}\right)\end{array}$ \\
\hline \multirow[t]{5}{*}{1} & 1 & 0.082 & 0.055 & 0.039 & 0.006 & 2.0E-07 & 0.014 \\
\hline & 1 & 0.059 & 0.031 & 0.041 & 0.008 & 7.1E-07 & 0.050 \\
\hline & 1 & 0.059 & 0.031 & 0.046 & 0.013 & 8.7E-07 & 0.061 \\
\hline & 1 & 0.041 & 0.013 & 0.034 & 0.001 & 2.8E-07 & 0.020 \\
\hline & 3 & 0.066 & 0.039 & 0.037 & 0.004 & 8.1E-07 & 0.057 \\
\hline \multirow[t]{5}{*}{2} & 1 & 0.109 & 0.081 & 0.035 & 0.002 & 1.6E-06 & 0.114 \\
\hline & 1 & 0.073 & 0.046 & 0.030 & 0.000 & 8.7E-07 & 0.061 \\
\hline & 1 & 0.059 & 0.032 & 0.037 & 0.004 & 6.6E-07 & 0.047 \\
\hline & 1 & 0.051 & 0.024 & 0.050 & 0.018 & 7.6E-07 & 0.053 \\
\hline & 3 & 0.068 & 0.040 & 0.049 & 0.016 & 1.1E-06 & 0.075 \\
\hline \multirow[t]{2}{*}{3} & 3 & 0.109 & 0.081 & 0.073 & 0.040 & 2.3E-06 & 0.162 \\
\hline & 4 & $0.068^{\circ}$ & 0.041 & $0.045^{\prime}$ & 0.012 & $9.6 E-07$ & 0.067 \\
\hline \multirow[t]{2}{*}{4} & 3 & 0.146 & 0.118 & 0.048 & 0.015 & $2.5 E-06$ & 0.178 \\
\hline & 4 & 0.130 & 0.102 & 0.046 & 0.013 & $2.3 E-06$ & 0.161 \\
\hline 5 & 7 & 0.144 & 0.117 & 0.062 & 0.029 & $2.8 E-06$ & 0.195 \\
\hline 6 & 7 & 0.174 & 0.146 & 0.094 & 0.061 & 3.8E-06 & 0.269 \\
\hline \multirow{6}{*}{ Blanks } & 3 & 0.026 & & 0.029 & & & \\
\hline & 7 & 0.027 & & 0.038 & & & \\
\hline & 7 & 0.031 & & 0.029 & & & \\
\hline & 1 & 0.029 & & 0.049 & & & \\
\hline & 1 & 0.030 & & 0.028 & & & \\
\hline & 1 & 0.024 & & 0.023 & & $\cdot$ & \\
\hline
\end{tabular}


Table C-2 Continued, AO Baseline

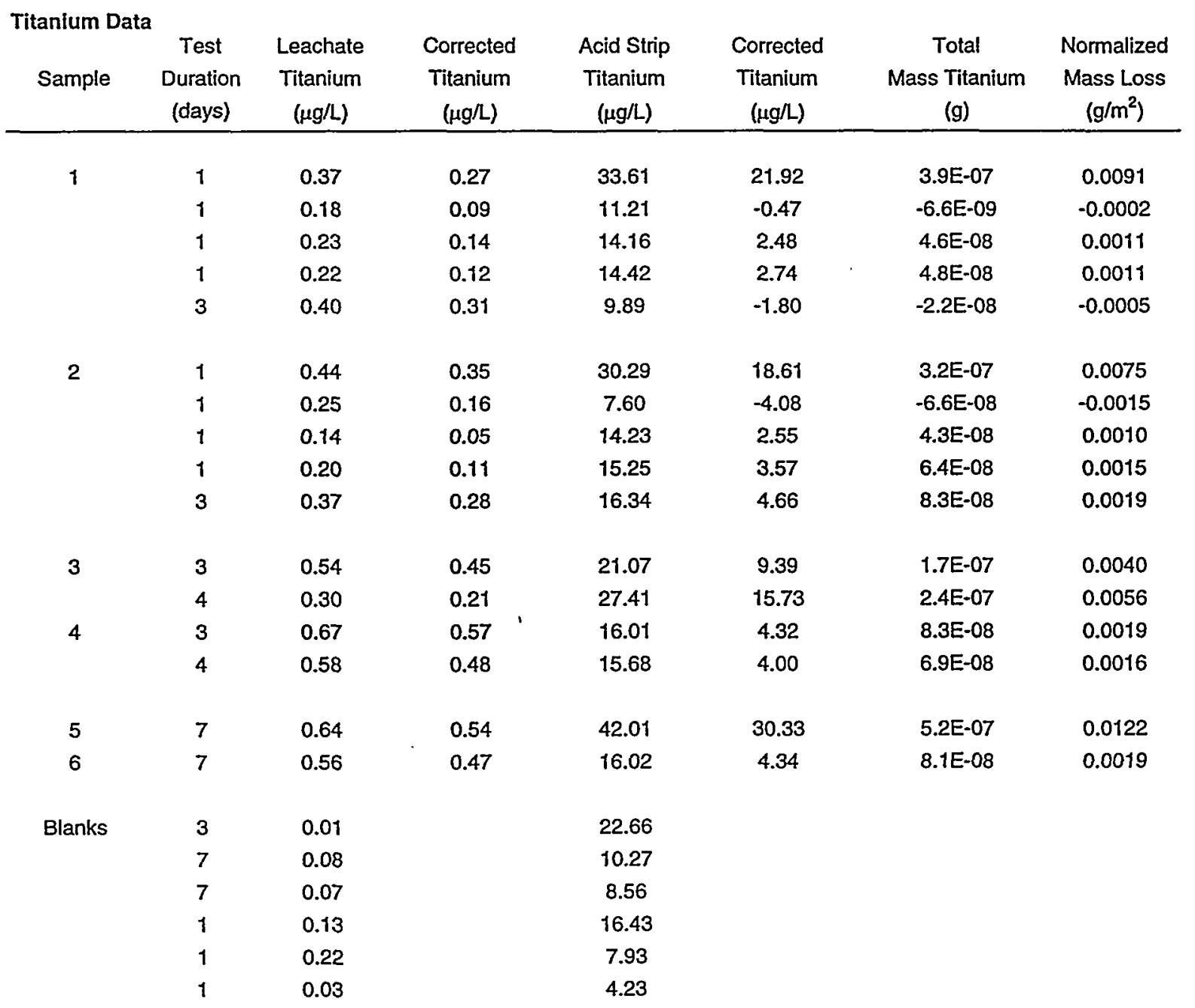


Table C-2 Continued, AO Baseline

Cerium Data

\begin{tabular}{|c|c|c|c|c|c|c|c|}
\hline Sample & $\begin{array}{c}\text { Test } \\
\text { Duration } \\
\text { (days) }\end{array}$ & $\begin{array}{l}\text { Leachate } \\
\text { Cerium } \\
(\mu \mathrm{g} / L)\end{array}$ & $\begin{array}{l}\text { Corrected } \\
\text { Cerium } \\
(\mu \mathrm{g} / \mathrm{L})\end{array}$ & $\begin{array}{l}\text { Acid Strip } \\
\text { Cerium } \\
(\mu \mathrm{g} / \mathrm{L})\end{array}$ & $\begin{array}{c}\text { Corrected } \\
\text { Cerium } \\
(\mu \mathrm{g} / \mathrm{L})\end{array}$ & $\begin{array}{c}\text { Total } \\
\text { Mass Cerium } \\
\text { (g) }\end{array}$ & $\begin{array}{c}\text { Normalized } \\
\text { Mass Loss } \\
\left(\mathrm{g} / \mathrm{m}^{2}\right)\end{array}$ \\
\hline \multirow[t]{5}{*}{1} & 1 & 0.50 & 0.16 & 33.19 & 24.30 & 4.3E-07 & 0.0075 \\
\hline & 1 & 0.30 & -0.04 & 8.42 & -0.47 & $-9.2 E-09$ & -0.0002 \\
\hline & 1 & 0.07 & -0.26 & 12.82 & 3.93 & $6.2 E-08$ & 0.0011 \\
\hline & 1 & 0.08 & -0.25 & 9.01 & 0.12 & $-3.3 E-09$ & -0.0001 \\
\hline & 3 & 0.25 & -0.09 & 11.58 & 2.69 & $4.0 \mathrm{E}-08$ & 0.0007 \\
\hline \multirow[t]{5}{*}{2} & 1 & 5.39 & 5.05 & 74.26 & 65.37 & 1.2E-06 & 0.0208 \\
\hline & 1 & 0.49 & 0.15 & 4.15 & -4.74 & -7.7E-08 & -0.0013 \\
\hline & 1 & 1.40 & 1.06 & 9.17 & 0.28 & $2.5 E-08$ & 0.0004 \\
\hline & 1 & 0.12 & -0.22 & 12.44 & 3.55 & 5.7E-08 & 0.0010 \\
\hline & 3 & 0.20 & -0.14 & 4.17 & -4.72 & $-8.1 E-08$ & -0.0014 \\
\hline \multirow[t]{2}{*}{3} & 3 & 9.83 & 9.49 & 17.74 & 8.85 & $3.4 \mathrm{E}-07$ & 0.0059 \\
\hline & 4 & 2.23 & 1.89 & 54.99 & 46.10 & 7.3E-07 & 0.0127 \\
\hline \multirow[t]{2}{*}{4} & 3 & 1.18 & $0.84^{\circ}$ & 30.65 & 21.76 & $3.8 E-07$ & 0.0065 \\
\hline & 4 & 0.27 & -0.07 & 17.99 & 9.10 & 1.3E-07 & 0.0023 \\
\hline 5 & 7 & 0.36 & 0.02 & 43.48 & 34.59 & 5.9E-07 & 0.0101 \\
\hline 6 & 7 & 0.10 & -0.24 & 11.03 & 2.14 & 3.1E-08 & 0.0005 \\
\hline \multirow[t]{6}{*}{ Blanks } & 3 & 0.32 & • & 15.56 & & & \\
\hline & 7 & 0.58 & & 7.20 & & & \\
\hline & 7 & 0.37 & & 9.91 & & & \\
\hline & 1 & 0.44 & & 11.33 & & & \\
\hline & 1 & 0.16 & & 7.15 & & & \\
\hline & 1 & 0.16 & & 2.19 & & & \\
\hline
\end{tabular}


Table C-2 Continued, AO Baseline

Gadolinium Data

\begin{tabular}{|c|c|c|c|c|c|c|c|}
\hline Sample & $\begin{array}{c}\text { Test } \\
\text { Duration } \\
\text { (days) }\end{array}$ & $\begin{array}{c}\text { Leachate } \\
\text { Gadolinium } \\
(\mu \mathrm{g} / \mathrm{L})\end{array}$ & $\begin{array}{c}\text { Corrected } \\
\text { Gadolinium } \\
(\mu \mathrm{g} / \mathrm{L})\end{array}$ & $\begin{array}{c}\text { Acid Strip } \\
\text { Gadolinium } \\
(\mu g / L)\end{array}$ & $\begin{array}{c}\text { Corrected } \\
\text { Gadolinium } \\
(\mu \mathrm{g} / \mathrm{L})\end{array}$ & $\begin{array}{c}\text { Total } \\
\text { Mass Gadolinium } \\
\text { (g) }\end{array}$ & $\begin{array}{c}\text { Normalized } \\
\text { Mass Loss } \\
\quad\left(\mathrm{g} / \mathrm{m}^{2}\right)\end{array}$ \\
\hline \multirow[t]{5}{*}{1} & 1 & 0.34 & 0.02 & 7.92 & 4.95 & $8.8 E-08$ & 0.0064 \\
\hline & 1 & 0.36 & 0.04 & 2.92 & -0.05 & $-8.6 E-11$ & -0.00001 \\
\hline & 1 & 0.29 & -0.03 & 6.99 & 4.02 & 6.9E-08 & 0.0050 \\
\hline & 1 & 0.21 & -0.11 & 2.93 & -0.04 & $-2.9 E-09$ & -0.0002 \\
\hline & 3 & 0.26 & -0.06 & 5.98 & 3.01 & 4.5E-08 & 0.0033 \\
\hline \multirow[t]{5}{*}{2} & 1 & 1.79 & 1.47 & 26.74 & 23.77 & 4.3E-07 & 0.0313 \\
\hline & 1 & 2.30 & 1.98 & 2.40 & -0.57 & 2.8E-08 & 0.0020 \\
\hline & 1 & 0.83 & 0.51 & 3.71 & 0.74 & 2.2E-08 & 0.0016 \\
\hline & 1 & 0.21 & -0.11 & 4.90 & 1.93 & 3.1E-08 & 0.0023 \\
\hline & 3 & 0.28 & -0.04 & 2.40 & -0.57 & $-1.0 E-08$ & -0.0009 \\
\hline \multirow[t]{2}{*}{3} & 3 & 4.48 & 4.16 . & 5.51 & 2.54 & 1.3E-07 & 0.0092 \\
\hline & 4 & 1.05 & 0.73 & 15.19 & 12.22 & 2.0E-07 & 0.0144 \\
\hline \multirow[t]{2}{*}{4} & 3 & 0.70 & 0.38 & 9.76 & 6.79 & 1.2E-07 & 0.0087 \\
\hline & 4 & 0.26 & -0.06 & 10.88 & 7.91 & 1.2E-07 & 0.0083 \\
\hline 5 & 7 & 0.27 & -0.05 & 11.55 & 8.58 & 1.4E-07 & 0.0105 \\
\hline 6 & 7 & 0.16 & -0.16 & 3.60 & 0.63 & 7.3E-09 & 0.0005 \\
\hline \multirow[t]{6}{*}{ Blanks } & 3 & 0.27 & & 3.10 & & & \\
\hline & 7 & 0.40 & & 2.74 & & & \\
\hline & 7 & 0.26 & & 4.25 & & & \\
\hline & 1 & 0.56 & & 2.83 & & & \\
\hline & 1 & 0.21 & & 3.54 & & & \\
\hline & 1 & 0.21 & & 1.37 & & & \\
\hline
\end{tabular}


Table C-2 Continued, AO Baseline

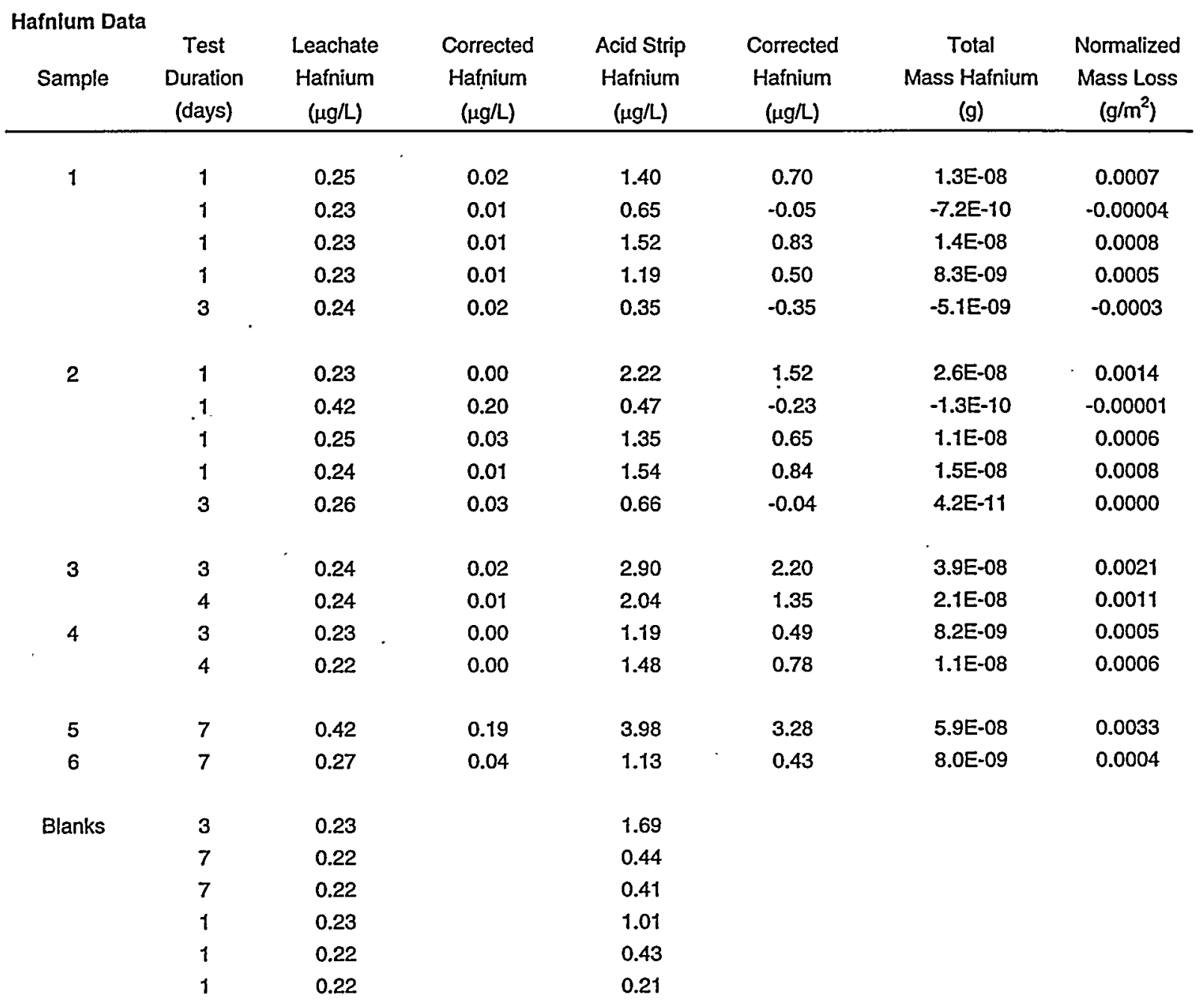




\section{APPENDIX D}

\section{ANALYTICAL DATA FOR CALCIUM ANALYSES FROM IRRADIATED AND UNIRRADIATED PNNL-FABRICATED SINGLE-PHASE PYROCHLORE CERAMIC LEACH TESTS}

Table D-1. Analytical Data from Successive 1-Day Leach Tests on Single-Phase Pyrochlore Ceramics, Data Set 1

Table D-1, Single-Phase Pyrochlore

Calcium Data:

\begin{tabular}{ccccccc} 
Sample $\begin{array}{c}\text { Test } \\
\text { Duration } \\
\text { (days) }\end{array}$ & $\begin{array}{c}\text { Leachate } \\
\text { Calcium } \\
(\mathrm{mg} / \mathrm{L})\end{array}$ & $\begin{array}{c}\text { Corrected } \\
\text { Calcium } \\
(\mathrm{mg} / \mathrm{L})\end{array}$ & $\begin{array}{c}\text { Acid Strip } \\
\text { Calcium } \\
(\mathrm{mg} / \mathrm{L})\end{array}$ & $\begin{array}{c}\text { Corrected } \\
\text { Calcium } \\
(\mathrm{mg} / \mathrm{L})\end{array}$ & $\begin{array}{c}\text { Total Mass } \\
\text { Calcium } \\
(\mathrm{g})\end{array}$ & $\begin{array}{c}\text { Normalized } \\
\text { Mass Loss } \\
\left(\mathrm{g} / \mathrm{m}^{2}\right)\end{array}$ \\
\hline Unirradiated Pellet 1 & & & & & & \\
1 & 0.046 & 0.024 & 0.151 & 0.100 & $2.2 \mathrm{E}-06$ & 0.173 \\
1 & 0.042 & 0.020 & 0.025 & -0.026 & $-7.5 \mathrm{E}-08$ & -0.006 \\
1 & 0.032 & 0.010 & 0.065 & 0.014 & $4.2 \mathrm{E}-07$ & 0.033 \\
1 & 0.037 & 0.015 & 0.005 & -0.046 & $-5.6 \mathrm{E}-07$ & -0.043
\end{tabular}

Unirradiated Pellet 2

$\begin{array}{lllllll}1 & 0.044 & 0.022 & 0.005 & -0.046 & -3.6 \mathrm{E}-07 & -0.029 \\ 1 & 0.032 & 0.010 & 0.027 & -0.024 & -2.2 \mathrm{E}-07 & -0.018 \\ 1 & 0.024 & 0.002 & 0.075 & 0.024 & 4.0 \mathrm{E}-07 & 0.032 \\ 1 & 0.065 & 0.043 & 0.070 & 0.019 & 1.1 \mathrm{E}-06 & 0.091\end{array}$

Irradiated Pellet 1

1

10.031

10.024

$1 \quad 0.026$

Irradiated Pellet 2

\section{1}

1

1

1

Blanks

\subsection{3}

0.019

0.022

0.025

0.023

0.009

0.017

0.024

0.020

0.033

0.029

$\begin{array}{ll}0.009 & 0.061 \\ 0.009 & 0.051 \\ 0.002 & 0.023 \\ 0.004 & 0.059\end{array}$

$-0.019$

$-0.003$

0.000

0.003

0.010
0.000
-0.028
0.008

3.3E-07

1.7E-07

$-4.5 E-07$

2.0E-07

$$
\begin{aligned}
& 0.000 \\
& -0.009 \\
& -0.046 \\
& -0.012
\end{aligned}
$$

0.029

0.040

0.035

0.054

0.097

0.037

0.066 
Table D-1 Continued, Single-Phase Pyrochlore

Titanium Data:

\begin{tabular}{cccccccc} 
Sample & $\begin{array}{c}\text { Test } \\
\text { Duration } \\
\text { (days) }\end{array}$ & $\begin{array}{c}\text { Leachate } \\
\text { Titanium } \\
(\mu \mathrm{g} / \mathrm{L})\end{array}$ & $\begin{array}{c}\text { Corrected } \\
\text { Titanium } \\
(\mu \mathrm{g} / \mathrm{L})\end{array}$ & $\begin{array}{c}\text { Acid Strip } \\
\text { Titanium } \\
(\mu \mathrm{g} / \mathrm{L})\end{array}$ & $\begin{array}{c}\text { Corrected } \\
\text { Titanium } \\
(\mu \mathrm{g} / \mathrm{L})\end{array}$ & $\begin{array}{c}\text { Total Mass } \\
\text { Titanium } \\
(\mathrm{g})\end{array}$ & $\begin{array}{c}\text { Normalized } \\
\text { Mass Loss } \\
\left(\mathrm{g} / \mathrm{m}^{2}\right)\end{array}$ \\
\hline Unirradiated Pellet 1 & & & & & & & \\
1 & 1.17 & 0.75 & 14.40 & 0.25 & $1.8 \mathrm{E}-08$ & 0.0004 \\
1 & 0.50 & 0.08 & 25.60 & 11.45 & $2.0 \mathrm{E}-07$ & 0.0038 \\
1 & 1.46 & 1.04 & 8.95 & -5.20 & $-6.9 \mathrm{E}-08$ & -0.0013 \\
1 & 1.22 & 0.80 & 10.70 & -3.45 & $-4.7 \mathrm{E}-08$ & -0.0009
\end{tabular}

Unirradiated Pellet 2

$\begin{array}{lllllll}1 & 1.25 & 0.83 & 8.36 & -5.79 & -8.2 \mathrm{E}-08 & -0.0016 \\ 1 & 3.08 & 2.66 & 9.71 & -4.44 & -2.4 \mathrm{E}-08 & -0.0005 \\ 1 & 0.27 & -0.15 & 29.60 & 15.45 & -2.4 \mathrm{E}-07 & 0.0046 \\ 1 & 21.00 & 20.58 & 49.00 & 34.85 & 9.9 \mathrm{E}-07 & 0.0193\end{array}$

Irradiated Pellet 1

$\begin{array}{ccccccc}1 & 0.51 & 0.09 & 21.30 & 7.15 & 1.2 \mathrm{E}-07 & 0.0023 \\ 1 & 0.51 & 0.09 & 10.10 & -4.05 & -6.4 \mathrm{E}-08 & -0.0012 \\ 1 & 1.02 & 0.60 & 9.48 & -4.67 & -7.0 \mathrm{E}-08 & -0.0013 \\ 1 & 0.74 & 0.32 & 9.73 & -4.42 & -6.6 \mathrm{E}-08 & -0.0013 \\ & & & & & & \\ \\ \text { et } 2 & & & & & & \\ 1 & 0.52 & 0.10 & 10.70 & -3.45 & -5.3 \mathrm{E}-08 & -0.0010 \\ 1 & 0.33 & -0.09 & 9.23 & -4.92 & -8.6 \mathrm{E}-08 & -0.0016 \\ 1 & 0.22 & -0.20 & 39.90 & 25.75 & 4.2 \mathrm{E}-07 & 0.0080 \\ 1 & 0.31 & -0.11 & 10.20 & -3.95 & -6.6 \mathrm{E}-08 & -0.0013\end{array}$

\begin{tabular}{|c|c|c|c|}
\hline \multirow[t]{7}{*}{ Blanks } & 1 & 0.41 & 9.18 \\
\hline & 1 & 0.37 & 18.50 \\
\hline & 1 & 0.34 & 16.50 \\
\hline & 1 & 0.97 & 21.40 \\
\hline & 1 & 0.41 & 11.80 \\
\hline & 1 & 0.30 & 16.60 \\
\hline & 1 & 0.25 & 10.90 \\
\hline
\end{tabular}


Table D-1 Continued, Single-Phase Pyrochlore

\section{Cerium Data:}

\begin{tabular}{cccccccc} 
Sample & $\begin{array}{c}\text { Test } \\
\text { Duration } \\
\text { (days) }\end{array}$ & $\begin{array}{c}\text { Leachate } \\
\text { Cerium } \\
(\mu \mathrm{g} / \mathrm{L})\end{array}$ & $\begin{array}{c}\text { Corrected } \\
\text { Cerium } \\
(\mu \mathrm{g} / \mathrm{L})\end{array}$ & $\begin{array}{c}\text { Acid Strip } \\
\text { Cerium } \\
(\mu \mathrm{g} / \mathrm{L})\end{array}$ & $\begin{array}{c}\text { Corrected } \\
\text { Cerium } \\
(\mu \mathrm{g} / \mathrm{L})\end{array}$ & $\begin{array}{c}\text { Total Mass } \\
\text { Cerium } \\
(\mathrm{g})\end{array}$ & $\begin{array}{c}\text { Normalized } \\
\text { Mass Loss } \\
\left(\mathrm{g} / \mathrm{m}^{2}\right)\end{array}$ \\
\hline Unirradiated Pellet 1 & & & & & & & \\
1 & 0.77 & -0.02 & 6.04 & -0.19 & $-3.7 \mathrm{E}-09$ & -0.00006 \\
1 & 1.95 & 1.16 & 5.80 & -0.43 & $1.4 \mathrm{E}-08$ & 0.00023 \\
1 & 1.29 & 0.50 & 5.68 & -0.55 & $2.1 \mathrm{E}-10$ & 0.00000 \\
1 & 25.27 & 24.48 & 15.70 & 9.47 & $6.4 \mathrm{E}-07$ & 0.01015
\end{tabular}

Unirradiated Pellet 2

$\begin{array}{ccccccc}1 & 0.71 & -0.08 & 6.39 & 0.16 & 1.1 \mathrm{E}-09 & 0.00002 \\ 1 & 3.86 & 3.06 & 3.14 & -3.09 & 7.3 \mathrm{E}-09 & 0.00012 \\ 1 & 0.27 & -0.52 & 4.74 & -1.49 & -3.3 \mathrm{E}-08 & -0.00053 \\ 1 & 3.77 & 2.98 & 4.34 & -1.89 & 2.5 \mathrm{E}-08 & 0.00040\end{array}$

Irradiated Pellet 1

$\begin{array}{llllll}0.31 & -0.48 & 6.72 & 0.49 & -1.2 \mathrm{E}-09 & -0.00002 \\ 0.31 & -0.48 & 11.10 & 4.87 & 7.0 \mathrm{E}-08 & 0.00112 \\ 1.32 & 0.53 & 6.28 & 0.05 & 1.0 \mathrm{E}-08 & 0.00017 \\ 0.88 & 0.09 & 8.20 & 1.97 & 3.4 \mathrm{E}-08 & 0.00054\end{array}$

Irradiated Pellet 2

$\begin{array}{llllll}0.90 & 0.11 & 9.30 & 3.07 & 5.1 \mathrm{E}-08 & 0.00081 \\ 1.35 & 0.56 & 5.55 & -0.68 & -9.4 \mathrm{E}-10 & -0.00001 \\ 4.22 & 3.43 & 8.67 & 2.44 & 1.0 \mathrm{E}-07 & 0.00162 \\ 0.77 & -0.02 & 10.90 & 4.67 & 7.5 \mathrm{E}-08 & 0.00119\end{array}$

$\begin{array}{cccc}\text { Blanks } & 1 & 0.43 & 4.15 \\ & 1 & 0.35 & 5.27 \\ & 1 & 0.65 & 3.20 \\ & 1 & 0.19 & 14.70 \\ & 1 & 0.18 & 7.70 \\ & 1 & 0.46 & 3.88 \\ & 1 & 1.57 & 6.93\end{array}$


Table D-1 Continued, Single-Phase Pyrochlore

\section{Gadolinium Data:}

\begin{tabular}{cccccccc} 
Sample & $\begin{array}{c}\text { Test } \\
\text { Duration } \\
\text { (days) }\end{array}$ & $\begin{array}{c}\text { Leachate } \\
\text { Gadolinium } \\
(\mu \mathrm{g} / \mathrm{L})\end{array}$ & $\begin{array}{c}\text { Corrected } \\
\text { Gadolinium } \\
(\mu \mathrm{g} / \mathrm{L})\end{array}$ & $\begin{array}{c}\text { Acid Strip } \\
\text { Gadolinium } \\
(\mu \mathrm{g} / \mathrm{L})\end{array}$ & $\begin{array}{c}\text { Corrected } \\
\text { Gadolinium } \\
(\mu \mathrm{g} / \mathrm{L})\end{array}$ & $\begin{array}{c}\text { Total Mass } \\
\text { Gadolinium } \\
(\mathrm{g})\end{array}$ & $\begin{array}{c}\text { Normalized } \\
\text { Mass Loss } \\
\left(\mathrm{g} / \mathrm{m}^{2}\right)\end{array}$ \\
\hline Unirradiated Pellet 1 & & & & & & & \\
1 & 0.56 & 0.19 & 5.13 & 2.38 & $4.6 \mathrm{E}-08$ & 0.00181 \\
1 & 1.15 & 0.78 & 2.97 & 0.22 & $1.8 \mathrm{E}-08$ & 0.00072 \\
1 & 0.64 & 0.27 & 3.55 & 0.80 & $1.9 \mathrm{E}-08$ & 0.00074 \\
1 & 11.00 & 10.63 & 8.38 & 5.63 & $3.0 \mathrm{E}-07$ & 0.01210
\end{tabular}

Unirradiated Pellet 2

$\begin{array}{lllllll}1 & 0.34 & -0.03 & 4.12 & 1.37 & 2.3 \mathrm{E}-08 & 0.00091 \\ 1 & 2.12 & 1.75 & 2.44 & -0.32 & 2.9 \mathrm{E}-08 & 0.00118 \\ 1 & 0.18 & -0.19 & 2.60 & -0.16 & -5.8 \mathrm{E}-09 & -0.00024 \\ 1 & 1.55 & 1.18 & 2.73 & -0.02 & 2.2 \mathrm{E}-08 & 0.00089\end{array}$

Irradiated Pellet 1

$\begin{array}{ccccccc}1 & 0.31 & -0.06 & 2.98 & 0.23 & 2.5 \mathrm{E}-09 & 0.00010 \\ 1 & 0.31 & -0.06 & 4.82 & 2.07 & 3.3 \mathrm{E}-08 & 0.00129 \\ 1 & 0.38 & 0.01 & 1.88 & -0.88 & -1.5 \mathrm{E}-08 & -0.00059 \\ 1 & 0.21 & -0.16 & 3.58 & 0.83 & 1.0 \mathrm{E}-08 & 0.00041 \\ & & & & & & \\ 12 & & & & & & \\ 1 & 0.34 & -0.03 & -4.56 & 1.81 & 2.8 \mathrm{E}-08 & 0.00112 \\ 1 & 0.62 & 0.25 & 2.40 & -0.36 & -1.4 \mathrm{E}-09 & -0.00006 \\ 1 & 1.80 & 1.43 & 3.07 & 0.32 & 3.1 \mathrm{E}-08 & 0.00123 \\ 1 & 0.26 & -0.11 & 5.13 & 2.38 & 3.6 \mathrm{E}-08 & 0.00143\end{array}$

$\begin{array}{llll}\text { Blanks } & 1 & 0.19 & 2.02 \\ & 1 & 0.18 & 2.50 \\ & 1 & 0.25 & 2.04 \\ & 1 & 0.19 & 3.10 \\ & 1 & 0.18 & 4.11 \\ & 1 & 0.23 & 1.95 \\ & 1 & 0.76 & 3.57\end{array}$


Table D-1 Continued, Single-Phase Pyrochlore

Hafnium Data:

\begin{tabular}{|c|c|c|c|c|c|c|c|}
\hline Sample & $\begin{array}{c}\text { Test } \\
\text { Duration } \\
\text { (days) }\end{array}$ & $\begin{array}{c}\text { Leachate } \\
\text { Hafnium } \\
(\mu \mathrm{g} / \mathrm{L})\end{array}$ & $\begin{array}{l}\text { Corrected } \\
\text { Hafnium } \\
(\mu \mathrm{g} / \mathrm{L})\end{array}$ & $\begin{array}{c}\text { Acid Strip } \\
\text { Hafnium } \\
(\mu g / L)\end{array}$ & $\begin{array}{c}\text { Corrected } \\
\text { Hafnium } \\
(\mu \mathrm{g} / \mathrm{L})\end{array}$ & $\begin{array}{l}\text { Total Mass } \\
\text { Hafnium } \\
\text { (g) }\end{array}$ & $\begin{array}{c}\text { Normalized } \\
\text { Mass Loss } \\
\left(\mathrm{g} / \mathrm{m}^{2}\right)\end{array}$ \\
\hline \multicolumn{8}{|c|}{ Unirradiated Pellet 1} \\
\hline & 1 & 0.24 & 0.04 & 1.02 & 0.50 & 9.7E-09 & 0.00191 \\
\hline & 1 & 0.31 & 0.11 & 0.29 & -0.23 & $-1.9 \mathrm{E}-09$ & -0.00037 \\
\hline & 1 & 0.21 & 0.01 & 0.72 & 0.20 & $3.6 \mathrm{E}-09$ & 0.00071 \\
\hline & 1 & 0.20 & 0.00 & 0.32 & -0.20 & $-3.5 E-09$ & -0.00069 \\
\hline \multicolumn{8}{|c|}{ Unirradiated Pellet 2} \\
\hline & 1 & 0.23 & 0.03 & 0.42 & -0.10 & $-1.1 \mathrm{E}-09$ & -0.00022 \\
\hline & 1 & 0.24 & 0.04 & 0.71 & 0.19 & $4.2 \mathrm{E}-09$ & 0.00083 \\
\hline & 1 & 0.27 & 0.08 & 0.79 & 0.27 & 5.6E-09 & 0.00111 \\
\hline & 1 & 0.27 & 0.07 & 0.54 & 0.03 & $1.8 E-09$ & 0.00036 \\
\hline \multicolumn{8}{|c|}{ Irradiated Pellet 1} \\
\hline & 1 & 0.21 & 0.01 & 2.15 & 1.63 & 2.7E-08 & 0.00529 \\
\hline & 1 & 0.21 & 0.01 & 0.33 & -0.19 & $-2.8 E-09$ & -0.00056 \\
\hline & 1 & 0.21 & 0.02 & 0.26 & -0.26 & $-4.2 E-09$ & -0.00083 \\
\hline & 1 & 0.22 & 0.02 & 0.34 & -0.18 & $-2.4 \mathrm{E}-09$ & -0.00048 \\
\hline \multicolumn{8}{|c|}{ Irradiated Pellet 2} \\
\hline & 1 & 0.21 & 0.01 & 0.51 & -0.01 & $7.9 \mathrm{E}-11$ & 0.00002 \\
\hline & 1 & 0.20 & 0.01 & 0.33 & -0.18 & $-3.0 E-09$ & -0.00059 \\
\hline & 1 & 0.20 & 0.01 & $\cdot 0.58$ & 0.06 & $1.2 \mathrm{E}-09$ & 0.00023 \\
\hline & 1 & 0.20 & 0.01 & 0.44 & -0.08 & $-1.1 E-09$ & -0.00021 \\
\hline
\end{tabular}

$\begin{array}{llll}\text { Blanks } & 1 & 0.20 & 0.18 \\ & 1 & 0.20 & 0.39 \\ 1 & 0.19 & 0.79 \\ 1 & 0.19 & 0.27 \\ 1 & 0.19 & 0.39 \\ 1 & 0.20 & 0.96 \\ & 1 & 0.20 & 0.56\end{array}$


Table D-1 Continued, Single-Phase Pyrochlore

Molybdenum Data:

\begin{tabular}{cccccccc} 
Sample & $\begin{array}{c}\text { Test } \\
\text { Duration } \\
\text { (days) }\end{array}$ & $\begin{array}{c}\text { Leachate } \\
\text { Molybdenum } \\
(\mu \mathrm{g} / \mathrm{L})\end{array}$ & $\begin{array}{c}\text { Corrected } \\
\text { Molybdenum } \\
(\mu \mathrm{g} / \mathrm{L})\end{array}$ & $\begin{array}{c}\text { Acid Strip } \\
\text { Molybdenum } \\
(\mu \mathrm{g} / \mathrm{L})\end{array}$ & $\begin{array}{c}\text { Corrected } \\
\text { Molybdenum } \\
(\mu \mathrm{g} / \mathrm{L})\end{array}$ & $\begin{array}{c}\text { Total Mass* } \\
\text { Molybdenum } \\
(\mathrm{g})\end{array}$ & $\begin{array}{c}\text { Normalized* } \\
\text { Mass Loss } \\
\left(\mathrm{g} / \mathrm{m}^{2}\right)\end{array}$ \\
\hline Unirradiated Pellet 1 & & & & & & & \\
1 & 0.07 & 0.02 & 8.23 & -4.58 & $3.7 \mathrm{E}-10$ & 0.0027 \\
1 & 0.10 & 0.05 & 12.00 & -0.80 & $9.3 \mathrm{E}-10$ & 0.0068 \\
1 & 0.14 & 0.09 & 16.01 & 3.20 & $1.7 \mathrm{E}-09$ & 0.0124 \\
1 & 0.13 & 0.08 & 14.44 & 1.63 & $1.5 \mathrm{E}-09$ & 0.0110
\end{tabular}

Unirradiated Pellet 2

$\begin{array}{lllllll}1 & 0.08 & 0.03 & 11.91 & -0.89 & 5.8 \mathrm{E}-10 & 0.0042 \\ 1 & 0.07 & 0.02 & 13.98 & 1.17 & 3.9 \mathrm{E}-10 & 0.0028 \\ 1 & 0.06 & 0.01 & 13.46 & 0.66 & 1.8 \mathrm{E}-10 & 0.0013 \\ 1 & 0.15 & 0.10 & 11.40 & -1.41 & 1.9 \mathrm{E}-09 & 0.0138\end{array}$

Irradiated Pellet 1

$\begin{array}{lllllll}1 & 0.08 & 0.03 & 10.12 & -2.68 & 5.8 \mathrm{E}-10 & 0.0042 \\ 1 & 0.19 & 0.14 & 12.00 & -0.81 & 2.6 \mathrm{E}-09 & 0.0192 \\ 1 & 0.05 & 0.00 & 13.60 & 0.80 & 0.0 \mathrm{E}+00 & 0.0000 \\ 1 & 0.09 & 0.04 & 11.84 & -0.96 & 7.6 \mathrm{E}-10 & 0.0055\end{array}$

Irradiated Pellet 2

$\begin{array}{lllllll}1 & 0.07 & 0.02 & 13.46 & 0.66 & 3.6 \mathrm{E}-10 & 0.0026 \\ 1 & 0.05 & 0.00 & 10.83 & -1.97 & 0.0 \mathrm{E}+00 & 0.0000 \\ 1 & 0.04 & -0.01 & 11.42 & -1.38 & -1.8 \mathrm{E}-10 & -0.0013 \\ 1 & 0.06 & 0.01 & 11.98 & -0.82 & 1.9 \mathrm{E}-10 & 0.0014\end{array}$

\begin{tabular}{|c|c|c|c|}
\hline \multirow[t]{7}{*}{ Blanks } & 1 & 0.05 & 15.06 \\
\hline & 1 & 0.05 & 9.96 \\
\hline & 1 & $<m d l$ & 14.07 \\
\hline & 1 & 0.06 & 8.33 \\
\hline & 1 & $<m d l$ & 9.33 \\
\hline & 1 & 0.07 & 12.21 \\
\hline & 1 & $<m d l$ & 9.58 \\
\hline
\end{tabular}

* Acid strip data for molybdenum was not used in calculated normalized mass loss for molybdenum, see text. 
Table D-2. Analytical Data from 3 and 7-Day Leaching of Single-Phase Pyrochlore Ceramics, Data Set 2

Table D-2, Single-Phase Pyrochlore

Calcium Data:

\begin{tabular}{|c|c|c|c|c|c|c|c|}
\hline Sample & $\begin{array}{c}\text { Test } \\
\text { Duration } \\
\text { (days) }\end{array}$ & $\begin{array}{l}\text { Leachate } \\
\text { Calcium } \\
\text { (mg/L) }\end{array}$ & $\begin{array}{l}\text { Corrected } \\
\text { Calcium } \\
\text { (mg/L) }\end{array}$ & $\begin{array}{l}\text { Acid Strip } \\
\text { Calcium } \\
\text { (mg/L) }\end{array}$ & $\begin{array}{c}\text { Corrected } \\
\text { Calcium } \\
\text { (mg/L) }\end{array}$ & $\begin{array}{l}\text { Total Mass } \\
\text { Calcium } \\
\text { (g) }\end{array}$ & $\begin{array}{c}\text { Normalized } \\
\text { Mass Loss } \\
\left(\mathrm{g} / \mathrm{m}^{2}\right)\end{array}$ \\
\hline \multicolumn{8}{|c|}{ Unirradiated } \\
\hline & 3 & 0.031 & 0.014 & 0.087 & 0.002 & 3.1E-07 & 0.024 \\
\hline & 7 & 0.023 & 0.013 & 0.049 & 0.014 & 5.0 E-07 & 0.039 \\
\hline \multicolumn{8}{|c|}{ Unirradiated } \\
\hline & 3 & 0.008 & -0.008 & 0.061 & -0.024 & $-6.1 \mathrm{E}-07$ & -0.049 \\
\hline & 7 & 0.012 & 0.001 & 0.050 & 0.015 & 3.2E-07 & 0.026 \\
\hline \multicolumn{8}{|l|}{$\begin{array}{l}\text { Irradiated } \\
\text { Pellet } 1\end{array}$} \\
\hline & 3 & 0.017 & 0.001 & 0.017 & -0.067 & $-1.2 E-06$ & -0.095 \\
\hline & 7 & 0.012 & 0.002 & 0.044 & 0.010 & 2.3E-07 & 0.018 \\
\hline \multicolumn{8}{|l|}{$\begin{array}{c}\text { Irradiated } \\
\text { Pellet } 2\end{array}$} \\
\hline & 3 & 0.008 & -0.008 & 0.049 & -0.036 & $-8.3 E-07$ & -0.064 \\
\hline & 7 & 0.011 & 0.000 & 0.029 & -0.005 & $-8.8 E-08$ & -0.007 \\
\hline
\end{tabular}

$\begin{array}{llll}\text { Blanks } & 3 & 0.022 & \\ & 3 & 0.013 & 0.085 \\ & 3 & 0.009 & \\ 3 & 0.021 & \\ 3 & 0.021 & 0.028 \\ 3 & 0.012 & 0.041 \\ 7 & 0.011 & \\ 7 & 0.014 & \\ 7 & 0.017 & \\ 7 & 0.011 & \\ 7 & 0.006 & \\ 7 & 0.006 & \end{array}$


Table D-2 Continued, Single-Phase Pyrochlore

Titanium Data:

\begin{tabular}{|c|c|c|c|c|c|c|c|}
\hline Sample & $\begin{array}{c}\text { Test } \\
\text { Duration } \\
\text { (days) }\end{array}$ & $\begin{array}{c}\text { Leachate } \\
\text { Titanium } \\
(\mu g / L)\end{array}$ & $\begin{array}{c}\text { Corrected } \\
\text { Titanium } \\
(\mu \mathrm{g} / \mathrm{L})\end{array}$ & $\begin{array}{c}\text { Acid Strip } \\
\text { Titanium } \\
(\mu \mathrm{g} / \mathrm{L})\end{array}$ & $\begin{array}{l}\text { Corrected } \\
\text { Titanium } \\
(\mu \mathrm{g} / \mathrm{L})\end{array}$ & $\begin{array}{l}\text { Total Mass } \\
\text { Titanium } \\
\text { (g) }\end{array}$ & $\begin{array}{c}\text { Normalized } \\
\text { Mass Loss } \\
\left(\mathrm{g} / \mathrm{m}^{2}\right)\end{array}$ \\
\hline \multicolumn{8}{|l|}{$\begin{array}{l}\text { Unirradiated } \\
\text { Pellet } 1\end{array}$} \\
\hline & 3 & 0.47 & 0.00 & 3.38 & 0.19 & 3.6E-09 & 0.00007 \\
\hline & 7 & 0.20 & 0.12 & 6.51 & 3.67 & 7.1E-08 & 0.00135 \\
\hline \multicolumn{8}{|l|}{$\begin{array}{l}\text { Unirradiated } \\
\text { Pellet } 2\end{array}$} \\
\hline & 3 & 0.47 & 0.00 & 2.98 & -0.21 & $-4.1 E-09$ & -0.00008 \\
\hline & 7 & 0.08 & 0.00 & 3.59 & 0.75 & 1.5E-08 & 0.00029 \\
\hline \multicolumn{8}{|l|}{$\begin{array}{l}\text { Irradiated } \\
\text { Pellet } 1\end{array}$} \\
\hline & 3 & 0.47 & 0.00 & 3.42 & 0.23 & 4.3E-09 & 0.00008 \\
\hline & 7 & 0.13 & 0.05 & 6.22 & 3.38 & $6.8 \mathrm{E}-08$ & 0.00130 \\
\hline \multicolumn{8}{|l|}{$\begin{array}{l}\text { Irradiated } \\
\text { Pellet } 2\end{array}$} \\
\hline & 3 & 0.47 & 0.00 & 2.26 & -0.93 & $-1.7 E-08$ & -0.00033 \\
\hline & 7 & 0.08 & 0.00 & 2.20 & -0.65 & $-1.2 E-08$ & -0.00023 \\
\hline \multirow[t]{12}{*}{ Blanks } & 3 & 0.47 & & & & & \\
\hline & 3 & 0.47 & & 3.19 & & & \\
\hline & 3 & 0.47 & & & & & \\
\hline & 3 & 0.47 & & & & & \\
\hline & 3 & 0.47 & & & & & \\
\hline & 3 & 0.47 & & & & & \\
\hline & 7 & 0.15 & & 2.91 & & & \\
\hline & 7 & 0.06 & & 2.78 & & & \\
\hline & 7 & 0.10 & & & & & \\
\hline & 7 & 0.06 & & & & & \\
\hline & 7 & $<$ mdl & & & & & \\
\hline & 7 & 0.06 & & & & & \\
\hline
\end{tabular}


Table D-2 Continued, Single-Phase Pyrochlore

Cerium Data:

\begin{tabular}{|c|c|c|c|c|c|c|c|}
\hline Sample & $\begin{array}{c}\text { Test } \\
\text { Duration } \\
\text { (days) }\end{array}$ & $\begin{array}{l}\text { Leachate } \\
\text { Cerium } \\
(\mu \mathrm{g} / \mathrm{L})\end{array}$ & $\begin{array}{c}\text { Corrected } \\
\text { Cerium } \\
(\mu \mathrm{g} / \mathrm{L})\end{array}$ & $\begin{array}{c}\text { Acid Strip } \\
\text { Cerium } \\
(\mu \mathrm{g} / \mathrm{L})\end{array}$ & $\begin{array}{l}\text { Corrected } \\
\text { Cerium } \\
(\mu \mathrm{g} / \mathrm{L})\end{array}$ & $\begin{array}{l}\text { Total Mass } \\
\text { Cerium } \\
\text { (g) }\end{array}$ & $\begin{array}{c}\text { Normalized } \\
\text { Mass Loss } \\
\qquad\left(\mathrm{g} / \mathrm{m}^{2}\right)\end{array}$ \\
\hline \multicolumn{8}{|l|}{$\begin{array}{l}\text { Unirradiated } \\
\text { Pellet } 1\end{array}$} \\
\hline & 3 & 0.27 & 0.15 & 4.69 & 2.42 & $4.9 \mathrm{E}-08$ & 0.00078 \\
\hline & 7 & 0.30 & 0.14 & 7.96 & 3.38 & $6.6 E-08$ & 0.00104 \\
\hline \multicolumn{8}{|l|}{$\begin{array}{l}\text { Unirradiated } \\
\text { Pellet } 2\end{array}$} \\
\hline & 3 & 0.27 & 0.15 & 1.94 & -0.33 & -3.7E-09 & -0.00006 \\
\hline & 7 & 0.17 & 0.02 & 2.27 & -2.31 & $-4.5 E-08$ & -0.00073 \\
\hline \multicolumn{8}{|l|}{$\begin{array}{l}\text { Irradiated } \\
\text { Pellet } 1\end{array}$} \\
\hline & 3 & 0.18 & 0.05 & 1.88 & -0.39 & $-6.2 E-09$ & -0.00010 \\
\hline & 7 & 0.60 & 0.44 & 6.90 & 2.32 & $5.4 \mathrm{E}-08$ & 0.00086 \\
\hline \multicolumn{8}{|l|}{$\begin{array}{l}\text { Irradiated } \\
\text { Pellet } 2\end{array}$} \\
\hline & 3 & 0.36 & 0.24 & 4.80 & 2.53 & $5.2 E-08$ & 0.00082 \\
\hline & 7 & 0.23 & 0.07 & 3.19 & -1.39 & $-2.4 \mathrm{E}-08$ & -0.00038 \\
\hline
\end{tabular}

$\begin{array}{llll}\text { Blanks } & 3 & 0.19 & \\ & 3 & 0.11 & 2.27 \\ & 3 & 0.13 & \\ 3 & 0.10 & \\ & 3 & 0.12 & 2.56 \\ & 3 & 0.10 & 6.60 \\ 7 & 0.20 & \\ 7 & 0.16 & \\ 7 & 0.12 & \\ 7 & 0.12 & \end{array}$


Table D-2 Continued, Single-Phase Pyrochlore

Gadolinium Data:

\begin{tabular}{|c|c|c|c|c|c|c|c|}
\hline Sample & $\begin{array}{c}\text { Test } \\
\text { Duration } \\
\text { (days) }\end{array}$ & $\begin{array}{c}\text { Leachate } \\
\text { Gadolinium } \\
(\mu \mathrm{g} / \mathrm{L})\end{array}$ & $\begin{array}{l}\text { Corrected } \\
\text { Gadolinium } \\
(\mu g / L)\end{array}$ & $\begin{array}{l}\text { Acid Strip } \\
\text { Gadolinium } \\
(\mu \mathrm{g} / \mathrm{L})\end{array}$ & $\begin{array}{c}\text { Corrected } \\
\text { Gadolinium } \\
(\mu \mathrm{g} / \mathrm{L})\end{array}$ & $\begin{array}{c}\text { Total Mass } \\
\text { Gadolinium } \\
\text { (g) }\end{array}$ & $\begin{array}{c}\text { Normalized } \\
\text { Mass Loss } \\
\left(\mathrm{g} / \mathrm{m}^{2}\right)\end{array}$ \\
\hline \multicolumn{8}{|l|}{$\begin{array}{l}\text { Unirradiated } \\
\text { Pellet } 1\end{array}$} \\
\hline & 3 & 0.19 & 0.13 & 2.52 & 1.52 & 3.1E-08 & 0.00125 \\
\hline & 7 & 0.19 & 0.15 & 1.94 & 0.65 & $1.5 E-08$ & 0.00059 \\
\hline \multicolumn{8}{|l|}{$\begin{array}{c}\text { Unirradiated } \\
\text { Pellet } 2\end{array}$} \\
\hline & 3 & 0.17 & 0.11 & 2.12 & 1.12 & $2.4 \mathrm{E}-08$ & 0.00097 \\
\hline & 7 & 0.08 & 0.04 & 1.46 & 0.17 & 4.2E-09 & 0.00017 \\
\hline \multicolumn{8}{|l|}{$\begin{array}{l}\text { Irradiated } \\
\text { Pellet } 1\end{array}$} \\
\hline & 3 & 0.08 & 0.02 & 0.93 & -0.07 & $-9.5 E-10$ & -0.00004 \\
\hline \multirow{2}{*}{\multicolumn{8}{|c|}{$\begin{array}{l}\text { Irradiated } \\
\text { Pellet } 2\end{array}$}} \\
\hline & & & & & & & \\
\hline & 3 & 0.13 & 0.07 & 1.89 & 0.89 & 1.8E-08 & 0.00071 \\
\hline & 7 & 0.05 & 0.01 & 1.28 & -0.01 & $-1.1 E-11$ & 0.00000 \\
\hline
\end{tabular}

$\begin{array}{llll}\text { Blanks } & 3 & 0.05 & \\ & 3 & 0.05 & 1.00 \\ & 3 & 0.06 & \\ 3 & 0.08 & \\ 3 & 0.05 & 1.13 \\ & 3 & 0.05 & 1.45 \\ 7 & 0.07 & \\ 7 & 0.05 & \\ 7 & <\text { mdl } & \\ 7 & <\text { mdl } & \\ 7 & <\text { mdl } & \\ 7 & 0.05 & \end{array}$


Table D-2 Continued, Single-Phase Pyrochlore

\section{Hafnium Data:}

\begin{tabular}{|c|c|c|c|c|c|c|c|}
\hline Sample & $\begin{array}{c}\text { Test } \\
\text { Duration } \\
\text { (days) }\end{array}$ & $\begin{array}{c}\text { Leachate } \\
\text { Hafnium } \\
(\mu \mathrm{g} / \mathrm{L})\end{array}$ & $\begin{array}{c}\text { Corrected } \\
\text { Hafnium } \\
(\mu \mathrm{g} / \mathrm{L})\end{array}$ & $\begin{array}{c}\text { Acid Strip } \\
\text { Hafnium } \\
(\mu \mathrm{g} / \mathrm{L})\end{array}$ & $\begin{array}{c}\text { Corrected } \\
\text { Hafnium } \\
(\mu \mathrm{g} / \mathrm{L})\end{array}$ & $\begin{array}{l}\text { Total Mass } \\
\text { Hafnium } \\
\text { (g) }\end{array}$ & $\begin{array}{c}\text { Normalized } \\
\text { Mass Loss } \\
\left(\mathrm{g} / \mathrm{m}^{2}\right)\end{array}$ \\
\hline \multicolumn{8}{|c|}{$\begin{array}{l}\text { Unirradiated } \\
\text { Pellet } 1\end{array}$} \\
\hline & 3 & $<$ mdl & - & 0.16 & 0.02 & $3.9 E-10$ & 0.00007 \\
\hline & 7 & $<$ mdl & - & 0.16 & 0.01 & $2.7 E-10$ & 0.00005 \\
\hline \multicolumn{8}{|c|}{$\begin{array}{l}\text { Unirradiated } \\
\text { Pellet } 2\end{array}$} \\
\hline & 3 & $<$ mdl & - & 0.14 & 0.00 & $4.5 E-11$ & 0.00001 \\
\hline & 7 & $<$ mdl & - & 0.16 & 0.02 & $3.6 E-10$ & 0.00006 \\
\hline \multicolumn{8}{|l|}{$\begin{array}{l}\text { Irradiated } \\
\text { Pellet } 1\end{array}$} \\
\hline & 3 & $<\mathrm{mdl}$ & - & 0.12 & -0.02 & $-3.3 E-10$ & -0.00006 \\
\hline \multirow{3}{*}{$\begin{array}{l}\text { Irradiated } \\
\text { Pellet } 2\end{array}$} & 7 & $<$ mdl & - & 0.17 & 0.03 & $5.4 \mathrm{E}-10$ & 0.00009 \\
\hline & 3 & $<\mathrm{mdl}$ & - & 0.18 & 0.03 & $6.2 E-10$ & 0.00011 \\
\hline & 7 & $<\mathrm{mdl}$ & - & 0.10 & -0.04 & $-6.5 E-10$ & -0.00011 \\
\hline
\end{tabular}

\begin{tabular}{|c|c|c|c|}
\hline \multirow[t]{12}{*}{ Blanks } & 3 & $<$ mdl & \\
\hline & 3 & $<\mathrm{mdl}$ & 0.11 \\
\hline & 3 & $<$ mdl & \\
\hline & 3 & $<\mathrm{mdl}$ & \\
\hline & 3 & $<$ mdl & \\
\hline & 3 & $<$ mdl & \\
\hline & 7 & $<$ mdl & 0.20 \\
\hline & 7 & $<$ mdl & 0.11 \\
\hline & 7 & $<$ mdl & \\
\hline & 7 & $<$ mdl & \\
\hline & 7 & $<\mathrm{mdl}$ & \\
\hline & 7 & $<\mathrm{mdl}$ & \\
\hline
\end{tabular}


Table D-2 Continued, Single-Phase Pyrochlore

\section{Molybdenum Data:}

\begin{tabular}{|c|c|c|c|c|c|c|c|}
\hline & $\begin{array}{l}\text { Test } \\
\text { Duration } \\
\text { (days) }\end{array}$ & $\begin{array}{l}\text { Leachate } \\
\text { Molybdenum } \\
(\mu \mathrm{g} / L)\end{array}$ & $\begin{array}{l}\text { Corrected } \\
\text { Molybdenum } \\
(\mu \mathrm{g} / \mathrm{L})\end{array}$ & $\begin{array}{l}\text { Acid Strip } \\
\text { Molybdenum } \\
(\mu \mathrm{g} / \mathrm{L})\end{array}$ & $\begin{array}{l}\text { Corrected } \\
\text { Molybdenum } \\
(\mu \mathrm{g} / \mathrm{L})\end{array}$ & $\begin{array}{l}\text { Total Mass* } \\
\text { Molybdenum } \\
\text { (g) }\end{array}$ & $\begin{array}{c}\text { Normalized* } \\
\text { Mass Loss } \\
\left(\mathrm{g} / \mathrm{m}^{2}\right)\end{array}$ \\
\hline
\end{tabular}

\begin{tabular}{|c|c|c|c|c|c|c|c|}
\hline \multicolumn{8}{|l|}{ Unirradiated } \\
\hline & 3 & 1.06 & 0.30 & 9.14 & 0.03 & 5.4E-09 & 0.037 \\
\hline & 7 & 0.40 & -0.37 & 7.69 & -1.42 & $-6.8 E-09$ & -0.046 \\
\hline \multicolumn{8}{|l|}{$\begin{array}{l}\text { Unirradiated } \\
\text { Pellet 2 }\end{array}$} \\
\hline & 3 & 0.70 & -0.06 & 12.19 & 3.08 & $-1.2 E-09$ & -0.008 \\
\hline & 7 & 0.63 & -0.14 & 8.64 & -0.47 & $-2.8 \mathrm{E}-09$ & -0.019 \\
\hline \multicolumn{8}{|l|}{ Irradiated } \\
\hline & 3 & 0.77 & 0.01 & 9.11 & 0.00 & $1.3 \mathrm{E}-10$ & 0.001 \\
\hline & 7 & 1.83 & 1.06 & 8.64 & -0.47 & $2.0 E-08$ & 0.137 \\
\hline \multicolumn{8}{|l|}{ Irradiated } \\
\hline & 3 & 0.75 & -0.01 & 10.37 & 1.26 & $-2.6 \mathrm{E}-10$ & -0.002 \\
\hline & 7 & 0.87 & 0.10 & 9.45 & 0.34 & $2.0 \mathrm{E}-09$ & 0.014 \\
\hline \multirow[t]{12}{*}{ Blanks } & 3 & 0.82 & & & & & \\
\hline & 3 & 0.59 & & 8.64 & & & \\
\hline & 3 & 0.56 & & & & & \\
\hline & 3 & 0.29 & & & & & \\
\hline & 3 & 1.70 & & & & & \\
\hline & 3 & 0.62 & & & & & \\
\hline & 7 & 0.71 & & 9.93 & & & \\
\hline & 7 & 0.64 & & 8.75 & & & \\
\hline & 7 & 1.06 & & & & & \\
\hline & 7 & 0.90 & & & & & \\
\hline & 7 & 0.66 & & & & & \\
\hline & 7 & 0.64 & & & & & \\
\hline
\end{tabular}

*Acid strip data for Molybdenum was not used in calculated normalized mass loss for molybdenum, see text. 


\section{APPENDIX E}

\section{ANALYTICAL DATA FOR CALCIUM ANALYSES FROM IRRADIATED AND UNIRRADIATED PNNL-FABRICATED SINGLE-PHASE ZIRCONOLITE CERAMIC LEACH TESTS}

Table E-1. Analytical Data from 3 and 7-Day Leaching of Single-Phase Zirconolite Ceramics

Table E-1, Single-Phase Zirconolite

Calcium Data:

\begin{tabular}{|c|c|c|c|c|c|c|c|}
\hline Sample & $\begin{array}{c}\text { Test } \\
\text { Duration } \\
\text { (days) }\end{array}$ & $\begin{array}{l}\text { Leachate } \\
\text { Calcium } \\
\text { (mg/L) }\end{array}$ & $\begin{array}{c}\text { Corrected } \\
\text { Calcium } \\
\text { (mg/L) }\end{array}$ & $\begin{array}{l}\text { Acid Strip } \\
\text { Calcium } \\
\text { (mg/L) }\end{array}$ & $\begin{array}{l}\text { Corrected } \\
\text { Calcium } \\
\text { (mg/L) }\end{array}$ & $\begin{array}{l}\text { Total Mass } \\
\text { Calcium } \\
\text { (g) }\end{array}$ & $\begin{array}{c}\text { Normalized } \\
\text { Mass Loss } \\
\left(\mathrm{g} / \mathrm{m}^{2}\right)\end{array}$ \\
\hline \multicolumn{8}{|c|}{ Unirradiated } \\
\hline 7 & 3 & 0.041 & 0.033 & 0.045 & 0.028 & 1.1E-06 & 0.048 \\
\hline & 7 & 0.053 & 0.029 & 0.009 & -0.020 & $1.9 E-07$ & 0.008 \\
\hline \multicolumn{8}{|c|}{ Unirradiated } \\
\hline Pellet 2 & 3 & 0.061 & 0.052 & 0.042 & 0.025 & 1.5E-06 & 0.067 \\
\hline & 7 & 0.026 & 0.002 & 0.078 & 0.048 & $9.8 \mathrm{E}-07$ & 0.043 \\
\hline \multicolumn{8}{|c|}{$\begin{array}{l}\text { Irradiated } \\
\text { Pellet } 1\end{array}$} \\
\hline & 3 & 0.046 & 0.038 & 0.018 & 0.001 & 7.3E-07 & 0.031 \\
\hline & 7 & 0.040 & 0.016 & 0.043 & 0.014 & 5.7E-07 & 0.024 \\
\hline \multicolumn{8}{|c|}{ Irradiated } \\
\hline & 3 & 0.016 & 0.007 & 0.011 & -0.006 & 2.9E-08 & 0.001 \\
\hline & 7 & 0.089 & 0.066 & 0.062 & 0.033 & $1.9 \mathrm{E}-06$ & 0.079 \\
\hline \multirow[t]{7}{*}{ Blanks } & 3 & 0.005 & & 0.019 & & & \\
\hline & 3 & 0.012 & & 0.008 & & & \\
\hline & 3 & 0.008 & & 0.024 & & & \\
\hline & 7 & 0.019 & & 0.025 & & & \\
\hline & 7 & 0.028 & & 0.029 & & & \\
\hline & 7 & 0.032 & & 0.011 & & & \\
\hline & 7 & 0.016 & & 0.053 & & & \\
\hline
\end{tabular}


Table E-1 Continued, Single-Phase Zirconolite

Titanium Data:

\begin{tabular}{|c|c|c|c|c|c|c|c|}
\hline Sample & $\begin{array}{c}\text { Test } \\
\text { Duration } \\
\text { (days) }\end{array}$ & $\begin{array}{c}\text { Leachate } \\
\text { Titanium } \\
(\mu \mathrm{g} / \mathrm{L})\end{array}$ & $\begin{array}{c}\text { Corrected } \\
\text { Titanium } \\
(\mu \mathrm{g} / \mathrm{L})\end{array}$ & $\begin{array}{c}\text { Acid Strip } \\
\text { Titanium } \\
(\mu \mathrm{g} / \mathrm{L})\end{array}$ & $\begin{array}{l}\text { Corrected } \\
\text { Titanium } \\
(\mu \mathrm{g} / \mathrm{L})\end{array}$ & $\begin{array}{l}\text { Total Mass } \\
\text { Titanium } \\
\text { (g) }\end{array}$ & $\begin{array}{l}\text { Normalizeo } \\
\text { Mass Loss } \\
\left(\mathrm{g} / \mathrm{m}^{2}\right)\end{array}$ \\
\hline \multicolumn{8}{|c|}{$\begin{array}{c}\text { Unirradiated } \\
\text { Pellet } 1\end{array}$} \\
\hline & 3 & 0.19 & 0.07 & 6.74 & 3.76 & 7.3E-08 & 0.0011 \\
\hline & 7. & 2.77 & 2.59 & 3.37 & -0.66 & 3.5E-08 & 0.0005 \\
\hline \multicolumn{8}{|l|}{$\begin{array}{c}\text { Unirradiated } \\
\text { Pellet } 2\end{array}$} \\
\hline & 3 & 0.18 & 0.06 & 6.93 & 3.95 & $7.8 \mathrm{E}-08$ & 0.0013 \\
\hline & 7 & 0.25 & 0.07 & 2.92 & -1.11 & $-2.0 \mathrm{E}-08$ & -0.0003 \\
\hline \multicolumn{8}{|l|}{$\begin{array}{l}\text { Irradiated } \\
\text { Pellet } 1\end{array}$} \\
\hline & 3 & 0.22 & 0.10 & 9.92 & 6.94 & 1.3E-07 & 0.0020 \\
\hline & 7 & 0.21 & 0.03 & 6.70 & 2.67 & 5.4E-08 & 0.0008 \\
\hline \multicolumn{8}{|l|}{$\begin{array}{l}\text { Irradiated } \\
\text { Pellet } 2\end{array}$} \\
\hline & 3 & 0.06 & -0.07 & 4.84 & 1.86 & $3.4 \mathrm{E}-08$ & 0.0005 \\
\hline & 7 & 0.42 & 0.24 & 3.02 & -1.01 & $-1.4 \mathrm{E}-08$ & -0.0002 \\
\hline \multirow[t]{7}{*}{ Blanks } & 3 & 0.06 & & 2.70 & & & \\
\hline & 3 & 0.06 & & 2.57 & & & \\
\hline & 3 & 0.06 & & 3.29 & & & \\
\hline & 7 & 0.22 & & 2.25 & & & \\
\hline & 7 & 0.19 & & 3.19 & & & \\
\hline & 7 & 0.17 & & 4.95 & & & \\
\hline & 7 & 0.13 & & 5.72 & & & \\
\hline
\end{tabular}


Table E-1 Continued, Single-Phase Zirconolite

Cerium Data:

\begin{tabular}{|c|c|c|c|c|c|c|c|}
\hline Sample & $\begin{array}{c}\text { Test } \\
\text { Duration } \\
\text { (days) }\end{array}$ & $\begin{array}{c}\text { Leachate } \\
\text { Cerium } \\
(\mu \mathrm{g} / \mathrm{L})\end{array}$ & $\begin{array}{c}\text { Corrected } \\
\text { Cerium } \\
(\mu \mathrm{g} / \mathrm{L})\end{array}$ & $\begin{array}{l}\text { Acid Strip } \\
\text { Cerium } \\
(\mu \mathrm{g} / \mathrm{L})\end{array}$ & $\begin{array}{l}\text { Corrected } \\
\text { Cerium } \\
(\mu \mathrm{g} / \mathrm{L})\end{array}$ & $\begin{array}{c}\text { Total Mass } \\
\text { Cerium } \\
\text { (g) }\end{array}$ & $\begin{array}{c}\text { Normalized } \\
\text { Mass Loss } \\
\left(\mathrm{g} / \mathrm{m}^{2}\right)\end{array}$ \\
\hline \multicolumn{8}{|c|}{$\begin{array}{l}\text { Unirradiated } \\
\text { Pellet } 1\end{array}$} \\
\hline & 3 & 0.26 & 0.16 & 2.10 & 0.67 & 1.6E-08 & 0.0010 \\
\hline & 7 & 1.60 & 1.31 & 1.87 & -0.97 & 5.8E-09 & 0.0004 \\
\hline \multicolumn{8}{|c|}{$\begin{array}{l}\text { Unirradiated } \\
\text { Pellet } 2\end{array}$} \\
\hline & 3 & $<\mathrm{mdl}$ & -0.07 & 5.72 & 4.29 & $8.2 E-08$ & 0.0055 \\
\hline & 7 & 0.14 & -0.16 & 1.09 & -1.75 & $-3.7 E-08$ & -0.0025 \\
\hline \multicolumn{8}{|l|}{$\begin{array}{l}\text { Irradiated } \\
\text { Pellet } 1\end{array}$} \\
\hline & 3 & 0.39 & 0.29 & 12.70 & 11.27 & 2.1E-07 & 0.0139 \\
\hline & 7 & 0.18 & -0.11 & 2.46 & -0.38 & $-9.6 E-09$ & -0.0006 \\
\hline \multicolumn{8}{|l|}{$\begin{array}{l}\text { Irradiated } \\
\text { Pellet } 2\end{array}$} \\
\hline & 3 & 0.05 & -0.05 & 2.97 & 1.54 & 2.8E-08 & 0.0018 \\
\hline & 7 & 0.09 & -0.21 & 2.64 & -0.20 & $-7.9 E-09$ & -0.0005 \\
\hline \multirow[t]{8}{*}{ Blanks } & 3 & 0.08 & & 1.12 & & & \\
\hline & 3 & $<$ mdl & & 0.87 & & & \\
\hline & 3 & 0.25 & & 2.37 & & & \\
\hline & & & & · & & & \\
\hline & 7 & 0.14 & & 1.10 & & & \\
\hline & 7 & 0.82 & & 1.56 & & & \\
\hline & 7 & 0.12 & & 3.11 & & & \\
\hline & 7 & 0.09 & & 5.59 & & & \\
\hline
\end{tabular}


Table E-1 Continued, Single-Phase Zirconolite

Gadolinium Data:

Test Leachate Corrected Acid Strip Corrected Total Mass Normalized

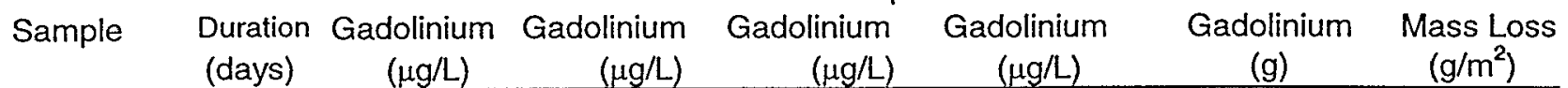

\begin{tabular}{|c|c|c|c|c|c|c|c|}
\hline \multicolumn{8}{|c|}{ Unirradiated } \\
\hline & 3 & $<\mathrm{mdl}$ & 0.00 & 1.30 & 0.43 & $8.2 E-09$ & 0.0014 \\
\hline & 7 & 0.07 & 0.00 & 1.46 & 0.56 & 1.0E-08 & 0.0018 \\
\hline \multicolumn{8}{|c|}{ Unirradiated } \\
\hline rellet 2 & 3 & $<\mathrm{mdl}$ & 0.00 & 0.87 & 0.00 & $5.8 \mathrm{E}-12$ & 0.0000 \\
\hline & 7 & 0.07 & 0.00 & 0.70 & -0.40 & $-7.8 E-09$ & -0.0014 \\
\hline \multicolumn{8}{|l|}{ Irradiated } \\
\hline Pellet 1 & 3 & $<$ mdl & 0.02 & 1.02 & 0.15 & 3.1E-09 & 0.0005 \\
\hline & 7 & 0.07 & 0.00 & 1.15 & 0.05 & $9.9 \mathrm{E}-10$ & 0.0002 \\
\hline \multicolumn{8}{|l|}{ Irradiated } \\
\hline Pellet 2 & 3 & $<$ mdl & 0.00 & 0.75 & -0.12 & $-2.2 E-09$ & -0.0004 \\
\hline & 7 & 0.07 & 0.00 & 0.76 & -0.34 & $-6.3 E-09$ & -0.0011 \\
\hline \multirow[t]{7}{*}{ Blanks } & 3 & $<\mathrm{mdl}$ & & 0.81 & & & \\
\hline & 3 & $<$ mdl & & 0.56 & & & \\
\hline & 3 & $<$ mall & & 1.33 & & & \\
\hline & 7 & 0.07 & & 0.69 & & & \\
\hline & 7 & 0.07 & & 0.81 & & & \\
\hline & 7 & 0.07 & & 0.96 & & & \\
\hline & 7 & 0.07 & & 1.14 & & & \\
\hline
\end{tabular}


Table E-1 Continued, Single-Phase Zirconolite

\section{Hafnium Data:}

\begin{tabular}{|c|c|c|c|c|c|c|c|}
\hline Sample & $\begin{array}{c}\text { Test } \\
\text { Duration } \\
\text { (days) }\end{array}$ & $\begin{array}{c}\text { Leachate } \\
\text { Hafnium } \\
(\mu \mathrm{g} / \mathrm{L})\end{array}$ & $\begin{array}{c}\text { Corrected } \\
\text { Hafnium } \\
(\mu \mathrm{g} / \mathrm{L})\end{array}$ & $\begin{array}{c}\text { Acid Strip } \\
\text { Hafnium } \\
(\mu \mathrm{g} / \mathrm{L})\end{array}$ & $\begin{array}{c}\text { Corrected } \\
\text { Hafnium } \\
(\mu \mathrm{g} / \mathrm{L})\end{array}$ & $\begin{array}{c}\text { Total Mass } \\
\text { Hafnium } \\
(\mathrm{g}) \\
\end{array}$ & $\begin{array}{c}\text { Normalized } \\
\text { Mass Loss } \\
\left(\mathrm{g} / \mathrm{m}^{2}\right)\end{array}$ \\
\hline \multicolumn{8}{|l|}{$\begin{array}{l}\text { Unirradiated } \\
\text { Pellet } 1\end{array}$} \\
\hline Pellet 1 & 3 & $<\mathrm{mdl}$ & 0.00 & 0.29 & 0.12 & 2.4E-09 & 0.000020 \\
\hline & 7 & $<$ mdl & 0.00 & 0.35 & 0.13 & 2.4E-09 & 0.000020 \\
\hline \multicolumn{8}{|l|}{ Unirradiated } \\
\hline \multirow{3}{*}{ Pellet 2} & & & & & : & & \\
\hline & 3 & $<\mathrm{mdl}$ & $0 . \dot{0} 0$ & 0.31 & 0.15 & 2.9E-09 & 0.000026 \\
\hline & 7 & $<$ mdl & 0.00 & 0.22 & -0.01 & $-8.3 E-11$ & -0.000001 \\
\hline \multicolumn{8}{|l|}{ Irradiated } \\
\hline rent I & 3 & $<$ mdl & 0.00 & 1.02 & 0.86 & 1.6E-08 & 0.000135 \\
\hline & 7 & $<$ mdl & 0.00 & 0.45 & 0.23 & 4.6E-09 & 0.000039 \\
\hline \multicolumn{8}{|l|}{ Irradiated } \\
\hline & 3 & $<\mathrm{mdl}$ & 0.00 & 0.54 & 0.37 & 7.0E-09 & 0.000058 \\
\hline & 7 & $<\mathrm{mdl}$ & 0.00 & 0.38 & 0.16 & $2.9 \mathrm{E}-09$ & 0.000025 \\
\hline
\end{tabular}

$\begin{array}{ccc}3 & <\text { mdl } & 0.14 \\ 3 & <\text { mdl } & 0.10 \\ 3 & <\text { mdl } & 0.29 \\ & & \\ & & \\ 7 & <\text { mdl } & 0.11 \\ 7 & <\text { mdl } & 0.12 \\ 7 & <\text { mdl } & 0.38 \\ 7 & <\text { mdl } & 0.29\end{array}$


Table E-1 Continued, Single-Phase Zirconolite

Molybdenum Data:

\begin{tabular}{|c|c|c|c|c|c|c|c|}
\hline Sample & $\begin{array}{l}\text { Test } \\
\text { Duration } \\
\text { (days) }\end{array}$ & $\begin{array}{c}\text { Leachate } \\
\text { Molybdenum } \\
(\mu \mathrm{g} / \mathrm{L})\end{array}$ & $\begin{array}{l}\text { Corrected } \\
\text { Molybdenum } \\
(\mu \mathrm{g} / \mathrm{L})\end{array}$ & $\begin{array}{l}\text { Acid Strip } \\
\text { Molybdenum } \\
(\mu \mathrm{g} / \mathrm{L})\end{array}$ & $\begin{array}{l}\text { Corrected } \\
\text { Molybdenum } \\
(\mu \mathrm{g} / \mathrm{L})\end{array}$ & $\begin{array}{l}\text { Total Mass* } \\
\text { Molybdenum } \\
\text { (g) }\end{array}$ & $\begin{array}{l}\text { Normalized* } \\
\text { Mass Loss } \\
\left(\mathrm{g} / \mathrm{m}^{2}\right)\end{array}$ \\
\hline \multicolumn{8}{|c|}{$\begin{array}{l}\text { Unirradiated } \\
\text { Pellet } 1\end{array}$} \\
\hline & 3 & 3.36 & 2.87 & 8.23 & 1.23 & 5.2E-08 & 0.277 \\
\hline & 7 & 4.88 & 4.33 & 6.53 & -0.50 & 7.9E-08 & 0.420 \\
\hline \multicolumn{8}{|c|}{$\begin{array}{l}\text { Unirradiated } \\
\text { Pellet } 2\end{array}$} \\
\hline & 3 & 5.12 & 4.63 & 6.04 & -0.96 & 8.7E-08 & 0.486 \\
\hline & 7 & 1.18 & 0.63 & 8.19 & 1.17 & 1.3E-08 & 0.070 \\
\hline \multicolumn{8}{|l|}{ Irradiated } \\
\hline Pellet 7 & 3 & 1.36 & 0.87 & 5.41 & -1.59 & 1.7E-08 & 0.090 \\
\hline & 7 & 1.34 & 0.79 & 8.32 & 1.30 & 1.5E-08 & 0.080 \\
\hline \multicolumn{8}{|l|}{ Irradiated } \\
\hline Pellet 2 & 3 & $1.00^{\circ}$ & 0.51 & 5.24 & -1.76 & 9.7 E-09 & 0.051 \\
\hline & 7 & 6.76 & 6.21 & 7.28 & 0.26 & $1.2 \mathrm{E}-07$ & 0.654 \\
\hline & & & & & & & $\cdot$ \\
\hline \multirow[t]{7}{*}{ Blanks } & 3 & 0.48 & & 7.51 & & & \\
\hline & 3 & 0.54 & & 6.50 & & & \\
\hline & 3 & 0.44 & & 6.21 & & & \\
\hline & 7 & 0.43 & & 7.58 & & & \\
\hline & 7 & 1.06 & & 8.10 & & & \\
\hline & 7 & 0.27 & & 6.09 & & & \\
\hline & 7 & 0.45 & & 6.33 & & & \\
\hline
\end{tabular}

*Acid strip data for molybdenum was not used in calculated normalized mass loss for molybdenum, see text. 